\title{
Some aspects of infection surveillance in open-heart surgery
}

Citation for published version (APA):

Staal, M. J. (1983). Some aspects of infection surveillance in open-heart surgery. [Doctoral Thesis, Maastricht University]. Rijksuniversiteit Limburg. https://doi.org/10.26481/dis.19830930ms

Document status and date:

Published: 01/01/1983

DOI:

10.26481/dis. $19830930 \mathrm{~ms}$

Document Version:

Publisher's PDF, also known as Version of record

\section{Please check the document version of this publication:}

- A submitted manuscript is the version of the article upon submission and before peer-review. There can be important differences between the submitted version and the official published version of record.

People interested in the research are advised to contact the author for the final version of the publication, or visit the DOI to the publisher's website.

- The final author version and the galley proof are versions of the publication after peer review.

- The final published version features the final layout of the paper including the volume, issue and page numbers.

Link to publication

\footnotetext{
General rights rights.

- You may freely distribute the URL identifying the publication in the public portal. please follow below link for the End User Agreement:

www.umlib.nl/taverne-license

Take down policy

If you believe that this document breaches copyright please contact us at:

repository@maastrichtuniversity.nl

providing details and we will investigate your claim.
}

Copyright and moral rights for the publications made accessible in the public portal are retained by the authors and/or other copyright owners and it is a condition of accessing publications that users recognise and abide by the legal requirements associated with these

- Users may download and print one copy of any publication from the public portal for the purpose of private study or research.

- You may not further distribute the material or use it for any profit-making activity or commercial gain

If the publication is distributed under the terms of Article $25 \mathrm{fa}$ of the Dutch Copyright Act, indicated by the "Taverne" license above, 
SOME ASPECTS OF INFECTION SUR VEILLANCE IN OPEN-HEART SURGERY 
. 


\section{SOME ASPECTS OF INFECTION SUR VEILLANCE IN OPEN-HEART SURGERY}

\section{PROEFSCHRIFT}

rer verkrijging van de graad van doctor in de geneeskunde aan de $\mathbb{R}$ ijksuniversiteit Limburg te Maastricht, op gezag van de Rector Magnificus Prof, Dr. H. C. Hemker, volgens besluit van het College van Dekanen in het openbaar te verdedigen in de aula van de universiteir op wrijdag 30 september 1983 , des namidldags te vier uur

$$
\text { door }
$$

MICHAEL JOSEPHUS ST'AAL

geboren te Amsterdam 
Promotores : Prof. Dr. C. P. A. van Boven

Prof. Dr. J. N. Homan van der Heide

Co-promotor : Drs. J. Dankert

Referenten : Prof. Dr. J. A. Flendrig

Prof. Dr. G. Kootstra

Dr. M. J. Haverkorn

Financial support by the Netherlands Heart Foundation for the publication of this thes is is gratefully acknowledged. 
Chapter II Patients, procedures, facilities, registration and occurrence of postoperative infections.............11

Chapter III Postoperative infections in open-heart surgery patients: relation between the causative microorganisms, the microorganisms isolated on admission and the microorganisms isolated from various

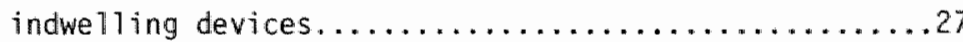

Chapter IV Detection and treatment of Staphy Zococous careus carriage in relation to the occurrence of postoperative Stophy lococous aureus infections..................55

Chapter $V \quad$ Bacteriological surveillance of the extra corporeal circuit; relation between the microorganisms isolated and those involved in the occurrence of postoperative bacteraemia, septicaemia and/or early-onset bacterial endocarditis...........75

Chapter VI The significance of isolation of Staphytococcus epidermidis from blood cultures obtained from patients after open-heart surgery...

Chapter VII General discussion and conclusions... .105

Chapter VIII Summary

Chapter IX Samenvatting...

Dankbetuiging 

CHAPTER I

INTRODUCTION 


\section{OPEN-HEART SURGERY AND PREVENTION OF INFECTIONS}

Open-heart surgery is one of the recent technological achievenents of modern medicine. In addition to the risk of infection associated with any operative techique, cardiac surgery and especially open-heart surgery has created a new group of infectious complications: postoperative infective endocarditis. Since the report of Koiwai (1) of 12 cases with postoperative infective endocarditis in 1190 patients after closed and open-heart operations, our understanding of the biology, diagnosis, treatment and prevention of this infection has increased considerably. The majority of publications on infections after cardiac surgery deals with postoperative endocarditis. Only a relative small number of reports also pays attiention to other infections associated with cardiac surgery.

Infections after cardiac surgery, a clean type of surgery, can be caused by so called "non pathogenic" microarganisms. These microorganisms constitute the endogenous microflora present or the skin and mucosa and are able to induce endocarditis after open-heart surgery (2).

There is a number of factors increasing the risk of acquiring infections after cardiac surgery: the extended use of prophylactic antibiotics (3-5), the presence of preoperative cardiac and extra-cardiac infections (6-8), the type of non-infective cardiac disease of the patient (9). Furthemore, it has been shown that patients with aortic valve disease have a higher risk of postoperative infection than patients with lesions of the other valves (10). The risk factors at operation may include the insertion of prosthetic material (11-13), the use of an extra corporeal circuit (14-17), the need for intravascular haemodymanic monitoring $(18-22)$, the large number of persons present in the operating room (23) and the lang duration of open-heart operations (24-26). Postoperative risk factors are mainly associated with intensive care treatment, such as the use of pressure transducers (18-22), intravascular catheters $(20,27-32)$ and continued mechanical respiratory assistance (33-36).

In open-heart surgery, antibiotics are administered prior, during and after operation to prevent postoperative infections. The rational for this prophylaxis has not been proven, but is felt to be necessary (37). Several antibiotics have been recommended, but the effectiveness of the different antibiotics is difficult to assess, because changes in operative technique and postoperative management will also affect the rate of infection (37).

Surveillance of infections which includes the registration of 
occurrence of infections and the bacteriological nonitoring of procedures perfomed, has been advacated for gaining insight into the transmission of microorganisms and the mechanisms involved in inducing the infections. Based on the results of the surveillance programe appropriate actions can be taken to reduce the occurrence of hospital associated infections (38).

The purpose of this study is to assess prospectively the efficacy of certain elements of the surveillance programe, as used in the first 18 months after starting cardiac surgery in the Catharina Hospital at Eindhoven, The Netherlands. Feasibility and cast-benefit analyses were not included in this study.

\section{SCOPE OF THE STUDY}

An inventory of the measure taken to maintain asepsis in the operating room and in the intensive care unit was made before open-heart surgery was initiated (Chapter II). Some measures were taken according to common practice while others were based on findings reported in the 1iterature. Because only certain elements of the total programe were evaluated, the results obtained from the prospective registration of infections should be seen as an overall assessment of all the precautions taken (Chapter II). In a number of reports, routine preoperative bacteriological culturing has been performed without evaluation of its significance with respect to the occurrence of postoperative infections $(39,40)$. Although a detailed bacteriological-epidemiological study was not performed, it was attempted by comparing the isolates from preoperative cultures with the isolates cultured from sites postoperatively shown to be infected, to assess the significance of such a routine culturing programe (Chapter III).

A feature often neglected in studies evaluating the efficacy of preventive measures is the accuracy of the sampling method used. The rate of staphylococous cureze carriage among patients and hospital personnel seems to be well known, but the detection of carriers is aften based upon single sampling. In addition the persisting carriage of staph.aureus in the microflora of the skin and mucous membranes has been questioned (41). In this study the accuracy of the sampling method and the constancy of staph.aureus carriage in patients and hospital personnel is studied (Chapter IV). The effect of the application of nasal antimicrobial ointment in patient carriers on the occurrence of postoperative infections due to staph. aureus was also 
studied (Chapter IV). Contamination of open-heart surgery patients can occur from various sources in the hospital (42). We chose to investigate one of these sources, the extra corporeal circuit, because of the conflicting reports in the 1 iterature $(23,43)$, concerning its significance as a cause of postoperative infections (Chapter $V$ ).

Intravascular infections due to staphylooocous epidermidis in open-heart surgery patients are serious and life threatening. This microorganism, of ten cansidered as a harmless microorganism present on the human skin and in the hospital environment, is an important cause of infections in patients with intravascular catheters (44) and arteriovenous and cerebrospinal fluid shunts (44-46), and in orthopaed ic surgery (45), vascular surgery (47) and open-heart surgery patients (45) after insertion of prosthetic material. However, the interpretation of stoph.epidermidis positive blood cultures taken from patients after open-heart surgery is often difficult due to the possibility of contamination. Differentiation of contaminated from true positive cultures due to bacteraemia or intravascular infections is based upon repeated isolation of this microorganism from a number of blood cultures taken within a certain time period. To get insight into the frequency of contamination during the collection and culturing of blood samples, in this study paired samples were postoperatively collected from open-heart surgery patients (Chapter VI). 


\section{REFERENCES}

1. Koiwai, E.K. and Nahas, H.C. Subacute bactemial endocarditis following cardiac surgery. Arch. Surg. 73: 272, 1956.

2. Norenberg, R.G., Sethi, G.K., Scott, S.M. and Takaro, T. Opportunistic endocarditis following open-heart surgery. Ann. Thorac. Surg. 19: 592,1975 .

3. Lord, J.W., Jr., Inparato, A.M., Hackel, A.H. and Doyle, E.F. Endocarditis complicating open-heart surgery. Circulation 23: 489, 1961.

4. Goldmann, D.A., Hopkins, C.C., Karchmer, A.W. Abel, R.M., Mc. Enany, M.T. Akins, C., Buckley, M.J. and Moellering, R.C., Jr. Cephalothin prophylaxis in cardiac valve surgery. A prospective double-blind comparison of two-day and six-day regimens. J.Thorac. Cardiovasc. Surg. 73: 470,7977 .

5. Penn, R.G., Sanders, W.E. and Sanders, C.C. Colonization of the oropharymx with gram-negative bacilli: A major antecedent to nosoconial pneumonia. Am.j. Inf.Contr. 9: 25, 1981.

6. Hughes, R.K. A method of improved anti-sepsis for open-heart surgery. Ann. Thorac.Surg. 2: $230,1966$.

7. Frater, R.W.M. and Santos, G.H. Sources of infection in open-heart surgery. N.Y. State J.Med. 74: 2386, 1974.

8. Dismukes, W.E. and Karchmer, A.W. The diagnosis of infected prosthetic heart valves: bacteremia versus endocarditis. In: R.J.Duma, ed. Infections of prosthetic heart valves and vascular grafts. Baltimore: University Park Press, 1977; 61.

9. Kaplan, E.L., Rich, H., Gersony, W., and Manning, J. A collaborative study of infective endocarditis in the 1970s. Emphasis on infections in patients who have undergone cardiovascular surgery. Circulation 59: $327,1979$. 

CHAPTER II

PATIENTS, PROCEDURES, FACILITIES, REGISTRATION AND OCCURRENCE OF POSTOPERATIVE INFECTIONS 


\section{PATIENTS}

From February 1978 to July 1979, 182 open-heart operations (table 1) were performed on 181 patients. One patient was re-admitted five months after a first aorto-coronary bypass graft (ACBG) operation. She was operated on a second time because of occlusion of the coronary bypass grafts. The data obtained during both admissions of this patient are used in this study as if obtained from two different patients.

Seven out of the 181 patients died. Four patients died on the day of operation: three after an ACBG operation, one after a mitral vallve replacement operation. One patient died several days after the second operation from causes unrelated to infection. Two other patients died several weeks after their operation due to a septicaemia and an early-onset bacterial endocarditis respectively.

Therefore the study includes 181 patients of whom all were included in the pre-operative study whereas 178 of them were available for the postoperative follow-up.

The age and sex distribution of the 181 patients is shown in table 2. The mean age of the 138 male patients was 51 years (range: 15-68 years). The mean age of the 43 female patients was 46 years (range: 8-69 years). The modal age class of the whole population was 50-59 years.

The indication for surgery, the type of operation and the use of prosthetic material are indicated in table 3.

\section{ARCHITECTURAL DESIGN AND FACILITIES OF THE DEPARTMENT}

The department of cardiac surgery was functionally and architecturally fulty integrated in a general hospital with 756 beds. This hospital was about five years old at the time of this study. Some structural alterations were made for the department of cardiac surgery.

\subsection{GENERAL WARD}

In a general ward with 43 beds, located on the seventh floor, patients were admitted preoperatively and re-admitted postoperatively after their stay on the intensive care unit. The thoracic drains and the urinary catheter were removed before the patient was transferred back to the 


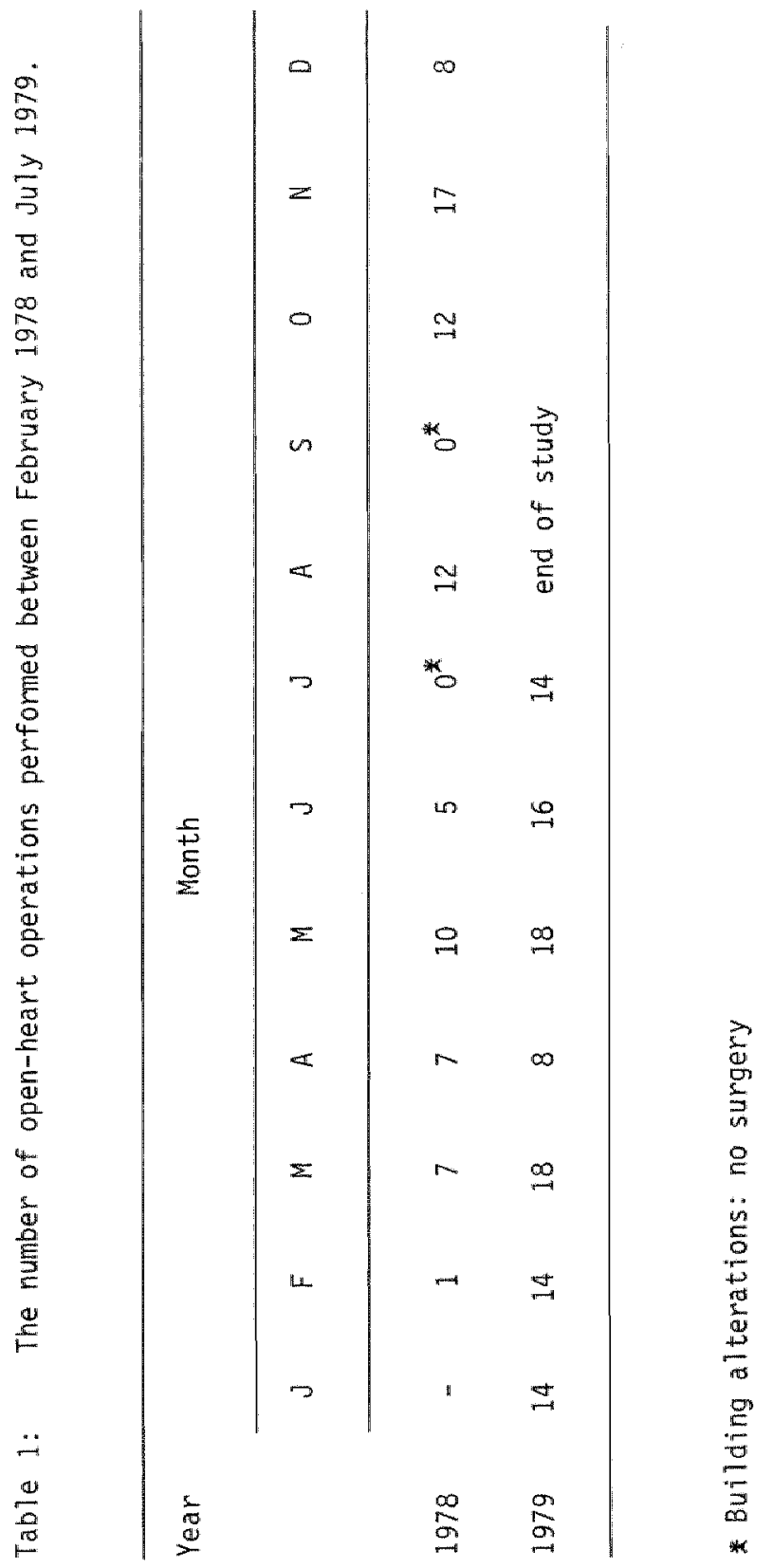


Table 2: Age and sex distribution of the patients.

\section{Patients}

Age group

$\overline{\text { Males }}$ Females Total

$\begin{array}{rrrr}0-9 \text { yrs. } & 0 & 1 & 1 \\ 10-19 \text { yrs. } & 3 & 8 & 11 \\ 20-29 \text { yrs. } & 5 & 0 & 5 \\ 30-39 \text { yrs. } & 2 & 1 & 3 \\ 40-49 \text { yrs. } & 45 & 7 & 52 \\ 50-59 \text { yrs. } & 68 & 18 & 86 \\ 60-69 \text { yrs. } & 15 & 8 & 23\end{array}$

Tatal

138

43

181 


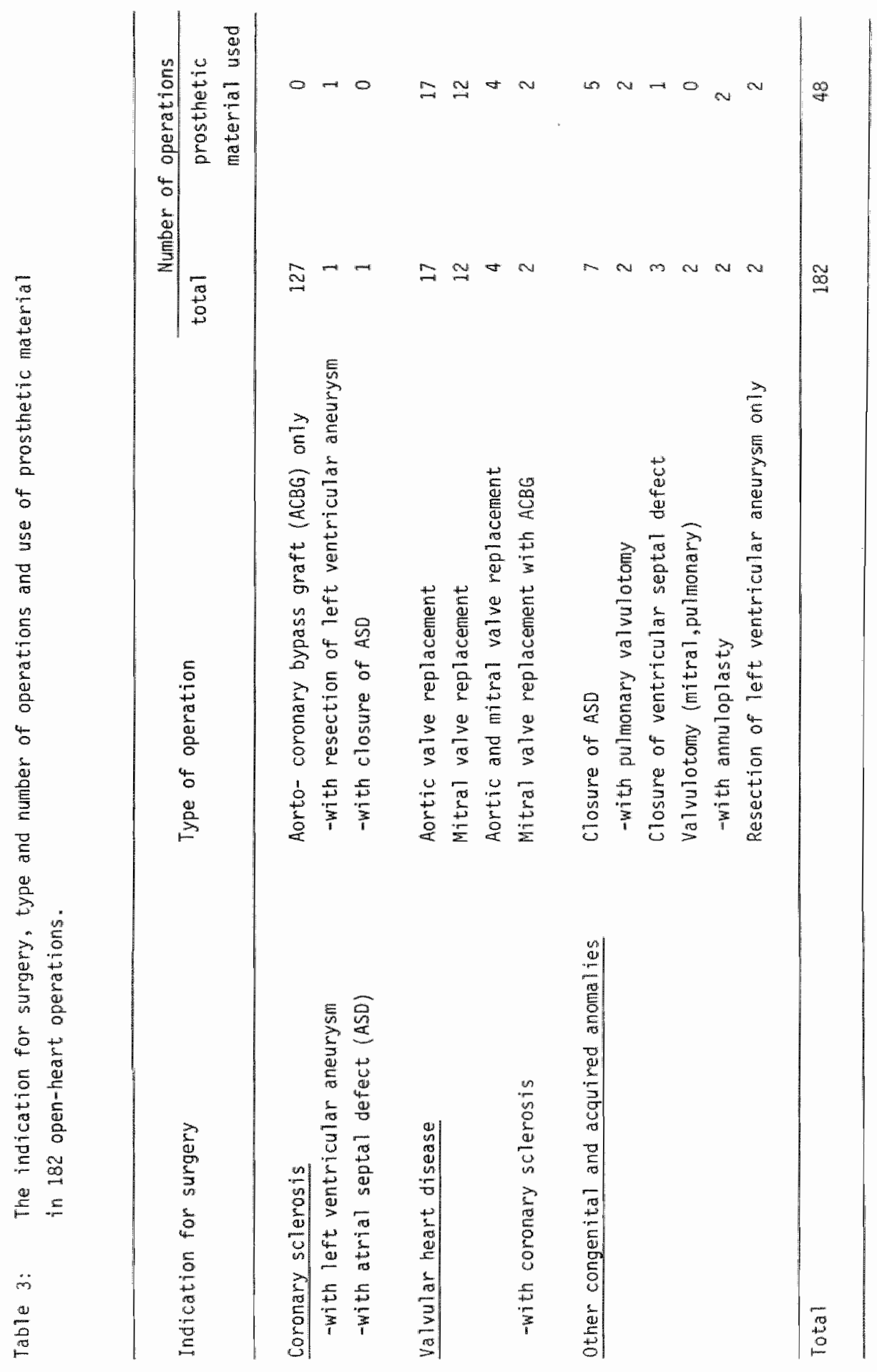


the general ward. On this ward there was a single room which could be used to isolate an infected patient when necessary.

\subsection{OPERATING-SUITE}

Two rooms in the operating-suite located on the second floor were used, though not exclusively, for cardio-thoracic operations. The ventilation system in the operating room had a multidirectional flow. Filtered air was introduced through perforated panels in the ceiling into each room and the air was exhausted through air-outlet opening in the walls one meter above the floor. The ventilation rate (air changes per hour) in the two rooms was 20 .

\subsection{INTENSIVE CARE UNIT}

Intensive care was given in two separate wards. A two-bed room for intensive care was adjacent to the recovery room of the operating suite. To reach this intensive care room cardiac surgery patients had to be transferred from the operating room through the recovery room. This two-bed room was entered from outside the operating-suite through an air-lock. The ventilation system provided an air-flow from the unit to the corridor outside.

The second room for the intensive care of cardiac surgery patients. was a four-bed roonl located on the seventh floor. This room, to which the patients were transferred after the first postoperative day, was part of the general intensive care unit of the hospital. Only cardio-thoracic and vascular surgery patients without evident infection were nursed in this four-bed room. The room was ventillated and the air-flow was directed from inside out. The room could only be entered through an air-lock. Cardiac surgery patients with an infection were transferred to an one-bed isolation room, or to a nine-bed room of the general intensive care unit, if the isolation room was occupied.

\section{CLINICAL PROCEDURES}

\subsection{PREOPERATIVE PERIOD}

\subsubsection{PATIENTS}


one hundred and sixty patients of the 182 patients were adnitted to the department of cardiac surgery directly from hone. The mean preoperative stay of these patients was eight days (range: 0-29 days).

Twenty-two patients were already in the hospital before being transferred to the departiment of cardiac surgery. The mean preoperative stay of this second group of patients before operation was 40 days (range: 10-110 days).

\subsubsection{BACTERIOLOGICAL SAMPLING AND INFECTIONS}

On the day of admission to the department of cardiac surgery samples for bacteriological culture were taken from several sites on the skin (axillae, chest, wrists, groins, perineum) and from the nose and throat. If patients were able to expectorate sputum a specimen was cultured. Midstream urine specimens were also cultured. All patients were preoperatively seen by an oto-rhino-laryngologist, a dental surgeon, a pulmonologist and if indicated by a urologist. The presence of an infection was a reason to postpone the operation.

\subsubsection{DISINFECTION OF THE SKIN}

A11 patients admitted to the department of cardiac surgery washed themselves (whole body washing) twice daily with liquid soap and shampoo containing povidone-iodine $10 \%$ and $7.5 \%$ respectively (Betadine $R$, Dagra, Diemen, The Netherlands).

\subsubsection{SHAVING PROCEDURE}

The evening before operation all patients, except emergency cases, were completely shaved, the hair of the scalp excluded. Shaving was done with a disposable razor blade. Skin disinfection was not performed afterwards.

\subsubsection{ANTIMICROBIAL PROPHYLAXIS}

The first 14 patients had amoxycillin administered prophylactically in an aral dose of $2 \times 750 \mathrm{mg}$ the day before surgery followed by ampic 111 in one hour prior to operation and three times daily for four days. To all other patients cephalothin was given prophylactically on the day of surgery, one gram intramuscullarly one hour before operation and intravenously at 
intervals of two hours during operation. After operation one gram was given at intervals of three hours. On the first day after operation cephalothin (one gram) was administered intravenously four times daily and then all prophylactic use of antibiotics was discontinued.

\subsection{INTQA-DPERATIVE PERIOD}

\subsubsection{IMMEDIATE PREOPERATIVE PREPARATION}

After induction of the anaesthesia and intubation, intravascular catheters used for haemodynamic monitoring and peripheral venous catheters were inserted by the anaesthesiologist who washed his hands with liquid soap containing povidone-iodine (Betadine ${ }^{R}$ ). A central venous pressure catheter was inserted into the jugular vein. An arterial pressure monitoring catheter was introduced into the radial artery. If indicated a left atrial pressure catheter was inserted by the surgeon before closure of the chest. The various intravascular pressure monitoring catheters were connected to electronic transducer systems. An indwelling urinary catheter was inserted aseptically "Body temperature was recorded using two sterilized temperature probes. One was placed in the oesophagus and the other in the rectum. A nasogastric tube was inserted. The skin of the patient was disinfected with iodine $(1 \% \mathrm{w} / \mathrm{v})$ in ethanol $(70 \% \mathrm{v} / \mathrm{v})$. The operative field was draped with plastic adhesive skin drapes (3M, St.Paul, Minn., USA) and with linen sheet5.

\subsubsection{THE SURGICAL SCRUB AND ATTIRE}

The members of the surgical team scrubbed their hands and forearms using autoclaved brushes and liquid soap containing povidone-iodine (Betadine $^{R}$ ) for five minutes. After drying hands and forearms with autoclaved linen towe1s they put on wraparound cotton, sterilized gowns. All males, including visitors, wore a clean trouser suit and all females wore a frock. The operating room staff wore clogs. The visitors used plastic shoe covers. The hair of the scalp of everyone present in the operating room was covered by a disposable cap. Disposable masks covered nose and mouth.

\subsubsection{THE EXTRA CORPOREAL CIRCUIT}

The equipment and procedures for the assembly, dismantling and bacterio- 
logical monitoring of the extra corporeal circuit are described in chapter $V$. The mean duration of extra corporeal circulation for the different types of surgery is shown in table 4.

\subsubsection{WOUND CARE}

The pericardium, the mediastinum and when necessary the pleura were drained with separate drains which were connected to disposable sterile, plastic drainage bottles (MölnIycke Steritex A/S, Espergaerde, Denimark). In the intensive care unit these bottles were placed on suction. If present, the wound in the leg was drained with a closed drainage system connected to disposable sterile vacuum bottles (Mölnlycke Steritex $A / S$ ). The wounds in chest and leg were dressed in the operating room using sterilized dressings.

\subsubsection{STERILIZATION AND CLEANING PROCEDURES}

The instruments were wrapped in 1 inen sheets and paper, sterilized by autoclaving and stored for at most one month. After operation the instruments were cleaned ultrasonically and washed in a washing machine. Sterile pack storage was separate from the room where used material was cleaned and wrapped. The respirator (Engström, Stockholm, Sweden) was sterilized once weekly in a formaldehyde steam sterilizer. Masks, tubing and other anaesthesia equipment were sterilized daily in formaline (4\% v/v). The floor of the operating room was disinfected for 30 minutes with $1 \%$ V/V Tyorthol (Lysoform ${ }^{R}$, Berlin) after each operation.

\subsubsection{MEAN DURATION OF OPERATIONS}

The mean duration of the different types of operation are shown in table 4.

\subsection{POSTOPERATIVE PERIOD}

\subsubsection{DURATION OF STAY IN THE INTENSIVE CARE UNIT}

The mean duration of stay in the intensive care unit was four days (range: 1-14 days). 


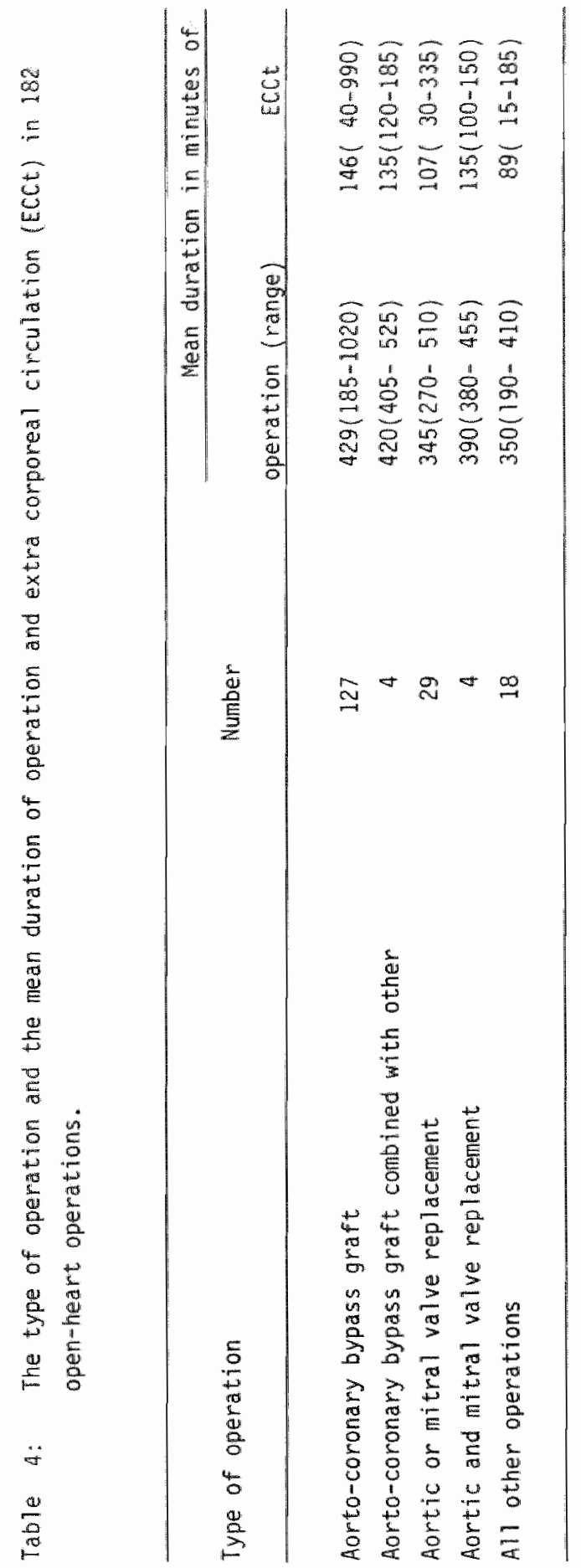




\subsubsection{VENTILATORY ASSISTANCE AND DURATION OF INTUBATION}

The patients were usually given ventilatory assistance using a respirator (Servo, Siemens, Elema, Sweden) until the morning of the first postoperative day. When the results of blood gas analysis while breathing spontaneously were satisfactory ventillatory assistance was terminated and the patients were extubated. Tubing of the respirator was sterilized by ineans of ethylene oxide. The humidifier and the nebulizer were filled with sterilized distilled water. The respirator was cleaned after extubation of the patients. During ventilatory assistance bronchial toilet and aspiration were perfomed as frequently as necessary. The bagging set was sterilized by means of ethylene oxide after extubation of the patient. The mean duration of the postoperative endotracheal intubation was one day (range:< 1-13 days). After extubation physiotherapy was used to improve patient's respiration.

\subsubsection{INTRAVASCULAR CATHETERS AND MEAN OURATION OF THEIR USE}

All the intravascular catheters used for pressure monitoring were removed as soon as the haemodymamic state permitted, usually on the first postoperative day. Intracardiac catheters were used in 110 patients. The mean duration of use of these catheters was one day (range:< 1-8 days). The intraarterial catheters were in place for a mean period of two days (range:< 1-11 days). Peripheral venous catheters were removed when the patient could drink again and if parenteral administration of medicines was not longer necessary. The intravenous catheter removed last had been applied for a mean period of three days (range: 1-30 days).

\subsubsection{URINARY TRACT CATHETERIZATION AND MEAN DURATION OF CATHETERIZATION}

The urinary indwelling catheter, inserted in the operating room was connected to a new sterile drainage bag (Urimeter, S.R. Bard International, Sunderland, U.K.). The urinary catheter was removed from 141 patients on the first postoperative day. The mean duration of catheterization was one day (range: $<1-16$ days).

\subsubsection{WOUND CARE AND DURATION OF DRAINAGE OF THE WOUND}


The dressings were removed from the wounds on the first postoperative day. The wounds were disinfected with a solution containing iodine (1 w $^{\prime} / \mathrm{V}$ ) in ethanol $(70 \% \mathrm{w} / \mathrm{v})$ and then covered with wound spray (Nobecutane, Bofors, Nobel Phama, Sweden). Closed drainage systems in the leg wounds were removed early. The duration of drainage of these wounds varied from one to seven days with a mean of two days. The tubes draining the pericardium, mediastinum and pleura were removed aseptically, when blood loss had become less than $20 \mathrm{ml}$ per hour. The thoracic drains were removed after about two days (range: $1-16$ days).

\subsubsection{CLEANING PROGRAMME DF THE INTENSIVE CARE LINIT}

cleaning of the intensive care unit was done once a day. Floors were cleaned with a detergent, and monitors, furniture and accessories with a damp duster. The one-bed isolation room was disinfected with $1 \% \mathrm{~V} / \mathrm{v}$ lyorthol (Lysoform) after the patient was transferred to the ward.

\subsubsection{PERSONNEL}

On the intensive care unit the staff wore caps, masks, plastic shoe covers and special clothing. When leaving this unit they covered their clothes with white coats. Visitors wore disposable gowns, caps, masks and plastic shoe covers. Before entering the intensive care unit in the air-lock, hands were washed with liquid soap containing povidone-iodine (Betadine ${ }^{R}$ ).

\section{REGISTRATION, DEFINITIONS AND OCCURRENCE OF POSTOPERATIVE INFECTIONS}

The registration of infections was performed prospectively. Patients were visited and, if necessary, examined daily during hospitalization. The results of laboratory tests and microbiological cultures were reviewed dafly. After discharge from the hospital patients were seen regularly at the out-patients' department up to 60 days postoperatively.

The criteria for postoperative infections were derived from the publication of Haley et al. (1) and were modified for the study.

Septicaemia was diagnosed when the patient had chills (except when occurring during a blood transfusion) and a positive blood culture, or 


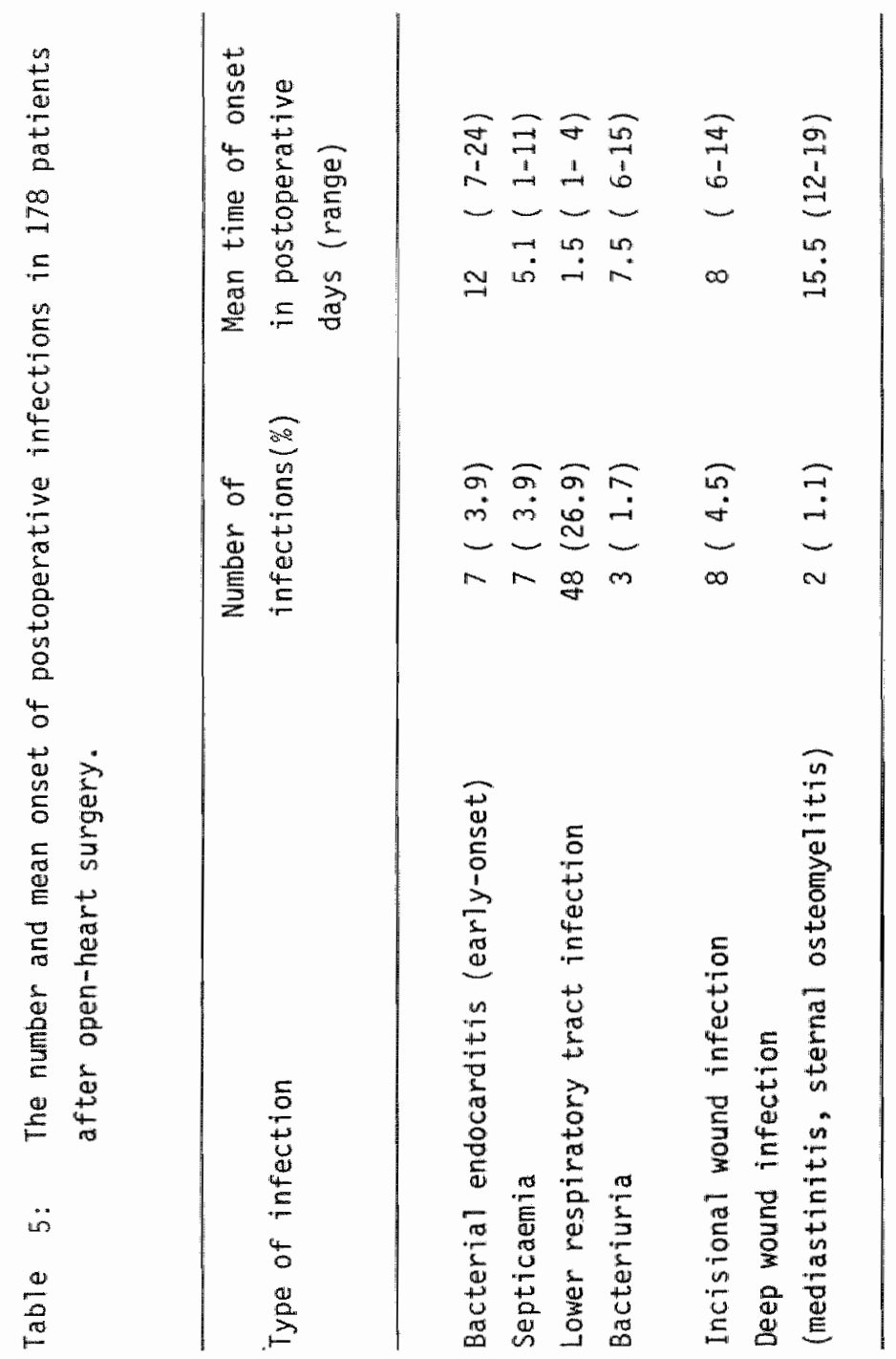


chills in conjunction with hypotension (systolic blood pressures 90 ma $\mathrm{Hg}$ ) without a postive blood culture.

Lower respiratory tract infection was present if a purulent sputum, a positlve culture and increased breath sounds were found.

Bacteriuria was present if a colony count showed the presence of $10^{5}$ or more bacteria of the same species $m 7^{-1}$ of urine.

Wound infection was defined as by presence of purulent drainage from the skin wound (incisional wound infection). Stitch abscesses were not registered as a wound infection. Mediastinitis (deep wound infection) was diagnosed if pus was encountered in the mediastinum at re-operation, whereas the diagnosis of sternal osteomyelitis as a deep wound infection was established by the presence of necrosis of the bone found at operative exploration.

The clinical diagnosis of postoperative early-onset bacterial endocarditis (within 60 days after operation) was based on the persistence of unexplained fever, the finding of persisting leucocytosis, the occurrence of a new regurgitant cardiac murnur and the results of blood cultures (at least two cultures positive for the same microorganism).

Fever (temperature $\geqslant 38.5^{\circ} \mathrm{C}$, measured recta11y) and leucocytosis $(\geqslant 10,000$ white blood cells per cubic millimeter) occurring within the first three postoperative days were not used as indices for the occurrence of postoperative infections. Both may be present within this period after openheart surgery in patients without infection (2-4).

Postoperative bacteriological sampling is described in detail in Chapter III.

Registration of postoperatiwe infections was performed on 178 patients, since four patients died on the day of operation. Of these 178 patients, 63 $(35 \%)$ had a postoperative infection (table 5). In 52 of these 63 patients a single infection occurred and in 11 patients more than one infection was diagnosed (ten patients with two infections, one patient with three infections). Early-anset bacterial endocarditis was diagnosed in seven (3.9\%) of the 178 patients. The mean onset of this infection was 12 days after surgery. In seven (3.9\%) other patients septicamia complincated the postoperative course. Lower respiratory tract infections were the most frequent7y encountered infectious complication occurring in 48 (26.9\%) patients, one to four days after the operation. Bacteriuria's occurred later but only in a small number of patients. Incisional wound infections were diagnosed in eight (4.5\%) of the 178 patients. Of these eight patients one had a sternal osteomyelitis, and another one had a mediastinitis followed by a septicaemia. 


\section{REFERENCES}

1. Haley, R.W., Quade, D., Freeman, H.E., Bennett, U.W. and the CDC Senic Planning Comittee. Study on the efficacy of nosocomial infection contral (SENIC Project). Am. E. Epideniol. 111: 472, 1980.

2. Goodman, J.S., Schaffner, W., Collins, H.A., Battersby, E.J. and Koenig, M.G. Infection after cardiovascular surgery. Clinical study including examination of antimicrobial prophylaxis. New. Engl.J.Med. 278:117,1968.

3. Be11, D.M., Goldmann, D.A., Hopkins, C.C., Karchmer, A.W. and Moellering, R.C. Unreliability of fever and leukocytosis in the diagnos is of infection after cardiac valve surgery. J.Thorac.Cardiovasc.Surg. 75: 87, 1978.

4. Pien, F.D., Ho, P.W.L. and Fergusson, D.J.G. Fever and infection after cardiac operation. Ann. Thorac. Surg. 33: 382,1982. 

POSTOPERATIVE INFECTIONS IN OPEN-HEART SURGERY PATIENTS:

RELATION BETWEEN THE CAUSATIVE MICROORGANISMS, THE MICROORGANISMS ISOLATED ON ADMISSION AND THE MICROORGANISMS ISOLATED FROM VARIOUS INDWELLING DEVICES 


\section{INTRODUCTION}

Open-heart surgery is associated with a higher frequency of postoperative infections than closed-heart procedures (1). The sources of milcroorganishs causing these infections can be many and are often difficult to trace $(2-5)$. The endogenous microflora, i.e. the resident microorganisms present on the surface of the skin and mucous membranes of the patient, is considered to be an important source especially since the skin and mucous membranes are penetrated during and after surgery. This creates a potential portal of entry to the tissues and the intravascular compartment. Preoperative microbiologicali culturing has been done in open-heart surgery patients $(1,4,5)$ but its usefulness in pin-pointing the relation between the isolated milcroorganisms and those causing postoperative infections has not been thoroughly studied. Postoperative endocarditis occurring within 60 days after surgery is considered as early-onset infective endocarditis, which is most frequently caused by microorganisms present in the normal flora of the human skin (6). However, contamination with such microorganisms may also occur from various sources in the operating room $(2,7-10)$. In addition postoperative infections of the respiratory tract $(11-13,15)$, the urinary tract $(11-13)$ and of wounds (11-15) are also potential sources of early-onset infective endocarditis. The microorganisms causing these extra-cardiac infections which by their accurrence create an extra postoperative risk for the patient, originate from a diversity of sources and reservoirs in and outside the operating room (16-19). Another source of infection identified after openheart surgery are intravascular catheters $(2,5,9,12,13)$. Other indwelling devices such as endotracheal tubes $(2,5)$, urinary catheters $(2,5,9,13)$ and thoracic drains (5) have been cultured postoperatively, but the rellation between the microorganisms isolated and those causing postoperative infections has not been convincingly demonstrated.

In this chapter, we report the occurrence of postoperative early-onset endocarditis and septicaemia, postoperative respiratory tract infection, bacteriuria and postoperative wound infection in 178 open-heart surgery patients. The aim of the study was to find a relation between the microorganisms isolated from samples taken preoperatively on admission from patients and the microorganisms causing these postoperative infections. In addition, the tips of various indwelling devices were cultured after removal in order to study a possible relation betweem the presence of microorganisms on the dewices and the microorganisms involved in subsequently occurring infections. 


\section{MATERIALS ANO METHODS}

\subsection{CULTURES ON ADMESSION}

One hundred and eighty two patients requiring open-heart surgery were sampled bacteriologically on the day of admission to the department of cardiac surgery. Samples were taken from several sites on the skin: axillae, chest, wrists, groins and perineum and also from the vestibules of the nose and from the throat using dry catton-tipped swabs. The swabs were transported in Amies Charcoal Medium (Transwab ${ }^{R}$, Medical Wire and Equipment co. Ltd. Potley, Corshan, Wilts., England). Sputum was culltured if patients were able to produce a specimen. Sputum samples were collected in sterilized vials.

Culturing was performed in the Laboratory for Medical Microbiology at Eindhoven, the Netherlands (M. J.Haverkorn).

\subsection{POSTOPERATIVE CULTURES}

Postoperative cultures were taken from only 178 patients, as four patients died on the day of surgery.

Blood cultures were taken if the body temperature, measured rectally, was raised above $38.5^{\circ} \mathrm{C}$. Blood $(10 \mathrm{ml})$ was drawn from an antecubital vein after cleansing of the skin with iodine $(11 \% \mathrm{w} / \mathrm{v})$ in ethanol $(70 \% \mathrm{v} / \mathrm{v})$. Five $\mathrm{ml}$ of blood was injected into $15 \mathrm{ml}$ Brain Heart Infusion (BHI) broth (Oxoid Ltd., Basingstoke, England) containing para-aminobenzoic acid $(0.01 \% \mathrm{w} / \mathrm{v})$, sodium citrate $(0.14 \% \mathrm{w} / \mathrm{v})$, white saponin $10.1 \% \mathrm{w} / \mathrm{v}$, Merck, A.G. Damstadt, Fed.Rep. Germany) and sufficient penicillinase (Mycafarm, Deift, The Netherlands) to counteract 10,000 units of penicillin. The other five ml of blood was injected into a bottle (LR-sample) containing two ml of sodium chloride solution $(0.85 \% \mathrm{~W} / \mathrm{V}$ ) and liquoid (sodium polyanethole sulphate $0.11 \% \mathrm{w} / \mathrm{v}$, Hoffmann-La Roche, Basel, Switzerland) and para-aminobenzoilc acid $(0.05 \% \mathrm{w} / \mathrm{w})$. After inoculation, the cultures were submitted to the Laboratory for Medical Microbiology at Eimdhoven.

Sputum samples were collected for bacteriological culture after removal of the endotracheal tube and when an infection of the respiratory tract was suspected.

Urinary samples were collected routinely from each patient on the morning of the first postoperative day and later if symptoms of an urinary tract. 
infection were present. Samples were collected from the chamber added to the drainage bag to measure the urine flow. When the catheter had been removed urine specimens from midstrean samples were collected. Urine samples were transported in sterillized vials.

wounds were sampled with dry cotton-tipped swabs if inflammation occurred or if exudate was produced. The swabs were inserted in Amies Charcod lied um.

When the intravascular and urinary tract catheters, the endotracheal tubes and the wound and thoracic drains had been removed, the tips were cut, using sterilized scissors, and transferred in sterilized vials for culturing.

Culturing was performed in the Laboratory for Medical Microbiology at Eindhoven.

\subsection{MICROBIOLOGICAL CULTURING, ANTIMICROBIAL SUSCEPTIB ILITY TESTING AND TYPING OF STAPHYLOCOCCI}

The cotton-tipped swabs were streaked routinely onto sheep blood (5\% v/V) agar (Oxaid) plates which were incubated aerobically at $37^{\circ} \mathrm{C}$ for 24 to 48 hours. In addition, the nasal and skin swabs were streaked onto mannitol salt agar (Oxoid No 110) for selective isolation of staphylococci. The swabs used for sampling the groins and the perineum were also streaked onto Macconkey agar (Oxoid Ltd.) for isolation of Enterobocteriaceae The throat samples were plated onto chocolate blood agar for isolation of Hamophitus species. The plates were incubated aerobically at $37^{\circ} \mathrm{C}$ for 24 to 48 hours, the chocolate blood agar plates were incubated in an atmosphere of $5 \% \mathrm{CO}_{2}$.

Aliquots of the sputum specinens were spread out in the inverted $1 \mathrm{id}$ of a Petri dish and then inspected for the presence of purulent portions. From each aliquot a purulent portion was washed three times in sterilized saline $\left(0.9^{*} \mathrm{w} / \mathrm{v}\right)$. Two portions of each aliquot were Gram stained and microscopically examined. The presence of leucocytes was noted. If more than 25 squamous epithelial cel1s per $100 \times$ field were seen, washings of purulent portions were repeated. If less than 25 squamous epithelial cells were seen, sheep blood, chocolate blood and MacConkey agar plates were inoculated qualitatively. The plates were incubated aerobically at $37^{\circ} \mathrm{C}$ for 24 hours, with the chocolate blood agar plates incubated in an atmosphere of $5 \% \mathrm{CO}_{2}$.

Blood cultures were processed as follows. Fron the first bottle containing BHI-saponin broth, three pour plates were prepared using 
Blood Agar Base nr. 2 (0xoid), containing glucose (1\% w/v). The bottle designated as the LR-sample was subcultured into Brewer Thioglycollate broth (Difco, Detroit, U.S.A.) and into BHI broth. In addition, a pour plate using Blood Agar Base nr. 2 containing glucose (1\% $w / v$ ) was prepared. The agar plates were incubated at $37^{\circ} \mathrm{C}$ for three days and the broth media for seven days. Three pour plates (one from the LR-sample and two from the BHI-sample) were incubated in an atmosphere of $5 \% \mathrm{CO}_{2}$. These were inspected daily. Subcultures were made when growth was seen. After five days, blind subculturing of the media was done on Blood Agar Base nr.2 containing heated sheep blood (5\%) and penicillin (0.1U), on a medium consisting of four parts oxoid G.C. Agar Base and one part Veal infusion medium ( $D$ ifCo) containing $5^{\circ}$ heated sheep blood agar and in a Brewer Thioglycollate broth. The latter medium was incubated for five days, the other media were incubated for two days. If growth was seen or if Gram stained smears indicated the presence of microorganisms, subcultures were performed on appropriate microbiologicall culture media.

Urine specimens were cultured semi-quantitatively. From each urine sample $0.1 \mathrm{ml}$ undiluted and $0.1 \mathrm{ml} 1: 100$ diluted urine were cultured onto sheep blood agar and MacConkey agar plates allowing after incubation at $37^{\circ} \mathrm{C}$ for 24 hours quantitation of the bacterial density in the sample. Microscopic examination of the Gram stained sediment was performed and the presence of uroepithelial cells, casts, leucocytes, erythrocytes and microorganisms was noted.

The tips of the different indwelling devices were rolled back and forth four times across the surface of sheep blood agar and MacConkey agar plates. Plates were incubated at $37^{\circ} \mathrm{C}$ for 24 hours.

Identification was performed by standard methods. The production of coagulase by staphylococci was tested by means of the tube test, using citrated rabbit plasma.

Antimicrobial susceptibility testing was performed using the disc diffusion method. The medium used was DST agar (Oxoid) and the discs used were Multodisks (0xoid). Sensitivity was recorded using standard diameters for zones of inhibition.

Stapinzococous aureus isolates were phage typed at the National Institute of Public Health at Bilthoven, The Netherlands (J. van Leeuwen). Stoph. aureus strains were considered to be identical if their phage type patterns were the same. All coagulase-negative staphylococci in this study were designated as Staphylococous epidermidis. These isolates were sent to 
the Department of Medical Microbiology of the State University of Limburg, The Netherlands (E.E.Stobberingh), for phage and biotyping. The methods used for typing and the phages used have been reported previously (20). Biotyping was performed using API-Staph gallery (API System S.A., Montalieu Vercleu, France). Strains were considered to be non-identical if they differed in one strong phage reaction or in one biotyping character.

With regard to the other microorganisms, the susceptibility patterns (antibiograms) were determined after identification. Isolates mere considered epldemiologically to be the same strain if these patterns were the same.

\subsection{DEFINITIONS AND REGISTRATION OF INFECTIONS}

Infections were defined and registered as described in Chapter II.

\subsection{STATISTICAL ANALYSIS}

Statistical significance was tested using the two tailed student $t$ test and the chi square test.

\section{RESULTS}

\subsection{CULTURES OF ADMISSION SAMPLES}

Eschemichia cotz was cultured from the samples obtained on admission from 155 (85\%) out of 182 patients (table 1). In a small number of patients this microorganism was present on the skin (groin, chest) and in the upper respiratory tract. Klebsiezla/Erterobater species, Proteus species and Poeudomonas cemginosa were cultured from $20 \%, 16 \%$ and $2 \%$ of the 182 patients, respectively. Other Gram-negative species were isolated from samples of a few patients. Of the Gram-positive microarganisms, staph.cureus was present in cultures taken from 65 (36\%) patients. Other Gram-positive microorganisms except $s t a p h$ epidermidis and viridans streptococci were isolated from a low number of patients. Sputum specimens were obtained from 97 patients on admission. From 81 of these specimens no microorganisms were isolated. Streptococous pnewmoniae was the microorganism most frequently cultured from sputum specinmens. 
Table 1: The bacterialogical culture results of samples collectad from 182 open-heart surgery patients on admission and of 97 sputum specintens.

\begin{tabular}{|c|c|c|c|c|c|c|}
\hline \multirow{2}{*}{ Microorganism } & \multicolumn{5}{|c|}{ Sampling site/specinen } & \multirow{2}{*}{$\begin{array}{l}\text { Number of } \\
\text { patients with } \\
\text { preoperative } \\
\text { isolation } \\
\text { of }(k)\end{array}$} \\
\hline & skin & nose & throat & sputum & perineun & \\
\hline \multicolumn{7}{|l|}{ Gram-negative } \\
\hline Eschericha con & 12 & 3 & 4. & 3 & 150 & $155 \quad(85)$ \\
\hline Klebsiella/Enterobacter species & 7 & 7 & 2 & 2 & 21 & $37(20)$ \\
\hline Proters wharis & 12 & 5 & 0 & 1 & 4 & $13(7)$ \\
\hline Protena mabilis & 4 & 1 & 1 & 1 & 9 & $16(9)$ \\
\hline Seratatia species & 1 & 0 & 0 & 0 & 1 & $2(1)$ \\
\hline Pseudomonas aemginosa & 1 & 0 & 1 & 0 & 1 & $3(2)$ \\
\hline Aoinetobacters species & 1 & 1 & 0 & 0 & 1 & $3(2)$ \\
\hline Homophizus influenzate & 0 & 3 & 0 & 5 & .0 & 8. (4) \\
\hline Heirsemia species & 0 & 2 & 7 & 0 & 0 & $9(5)$ \\
\hline \multicolumn{7}{|l|}{ Gram-positive } \\
\hline Staphy Locoosus aureus & 12 & 56 & 19 & 0 & 7 & $65(36)$ \\
\hline Staphy tooodcus eptderriats & 180 & 133 & 5 & 0 & 158 & $182(100)$ \\
\hline Sarcund species & 2 & 0 & 0 & 0 & 0 & $2(1)$ \\
\hline Haemolytic streptococcus & & & & & & \\
\hline $\begin{array}{l}\text { group A } \\
\text { Hoenolytic streptococcus }\end{array}$ & $a$ & 1 & 2 & 0 & 0 & $3(2)$ \\
\hline non-group & 2 & $\mathbb{1}$ & 13 & 1 & 14 & $27(15)$ \\
\hline streptooocoud biridans group & 2 & 3 & 157 & 0 & 11 & $163(90)$ \\
\hline Streptocoows pnewnoniae & 0 & 7 & 0 & 9 & 0 & $16(9)$ \\
\hline Stweptooocons faecatio & 1 & 0 & 0 & 1 & 11 & $11(6)$ \\
\hline Indifferent streptocacci & 0 & 0 & 0 & 0 & 3 & $3(2)$ \\
\hline Diphteroids & 2 & 1 & 0 & 0 & 6 & $9(5)$ \\
\hline Wo isolate & 0 & 37 & 3 & 81 & 7 & \\
\hline
\end{tabular}




\subsection{INCIDENCE OF POSTOPERATIVE INFECTIONS AND THEIR CAUSATIVE MICRODRGANISMS}

IN RELATION TO MICROORGAMISMS ISOLATED ON ADMISSION AND TO MICROORGANISMS ISOLATED FROM VARIOUS INDWELLING DEVICES

Postoperative infections occurred in $63(35 \%)$ of 178 open-heart surgery patients. Single infections were diagnosed in 52 patients, whereas 11 patients had more than one postoperative infection (see Chapter II).

\subsubsection{EARLY-ONSET BACTERIAL ENDOCARDITIS AND SEPTICAEMIA}

Early-onset bacterial endocarditis occurred in six (18\%) out of 34 patients who underwent valve replacement surgery (table 2). This infection did not occur in 11 other patients undergoing various operations entailing insertion of prosthetic materiat. Of the remaining 133 patients, early-onset bacterial endocarditis occurred in one patient who had undergone a direct closure of a ventricular septal defect.

Septicaemia occurred in seven patients. All of them underwent an aorto-coronary bypass graft operation (table 2). In table 3 the microorganisms causing these infections are given. Bacterial endocarditis was due to Gram-positive microorganisms (mainly Staph.epidexmidis), sensitive for cephalothin, the antibiotic used for prophylaxis. Septicaemia was caused by Gram-positive or Gram-negative microorganisms. One patient had a polymicrobial septicaemia due to Staph.epidermidis and Ps.aernginosa. Results of susceptibility testing showed that the Gram-positive isolates were sensitive for cephalothin and that the Gram-negative isolates were resistant.

Besides susceptibility testing, staph.epidermidis causing early-onset bacterial endocarditis were phage and biotyped. The results of the typing of these strains were compared to those of the staph.epidexmidis strains isolated from the specimens abtained on admission. Phage typing revealed that the four strains causing this infection were non-typable. The other two methods showed that in three of the five patients the Staph.epidermidis strain causing the infection was similar to a strain present in the skin flora on admission, and in one of the five patients similar to a strain present in the nasal flora.

The causative microorganisms in most of the patients with septicaemia could not be isolated from the specimens taken on admission, or differed in their susceptibility patterns and/or biotypes from strains 


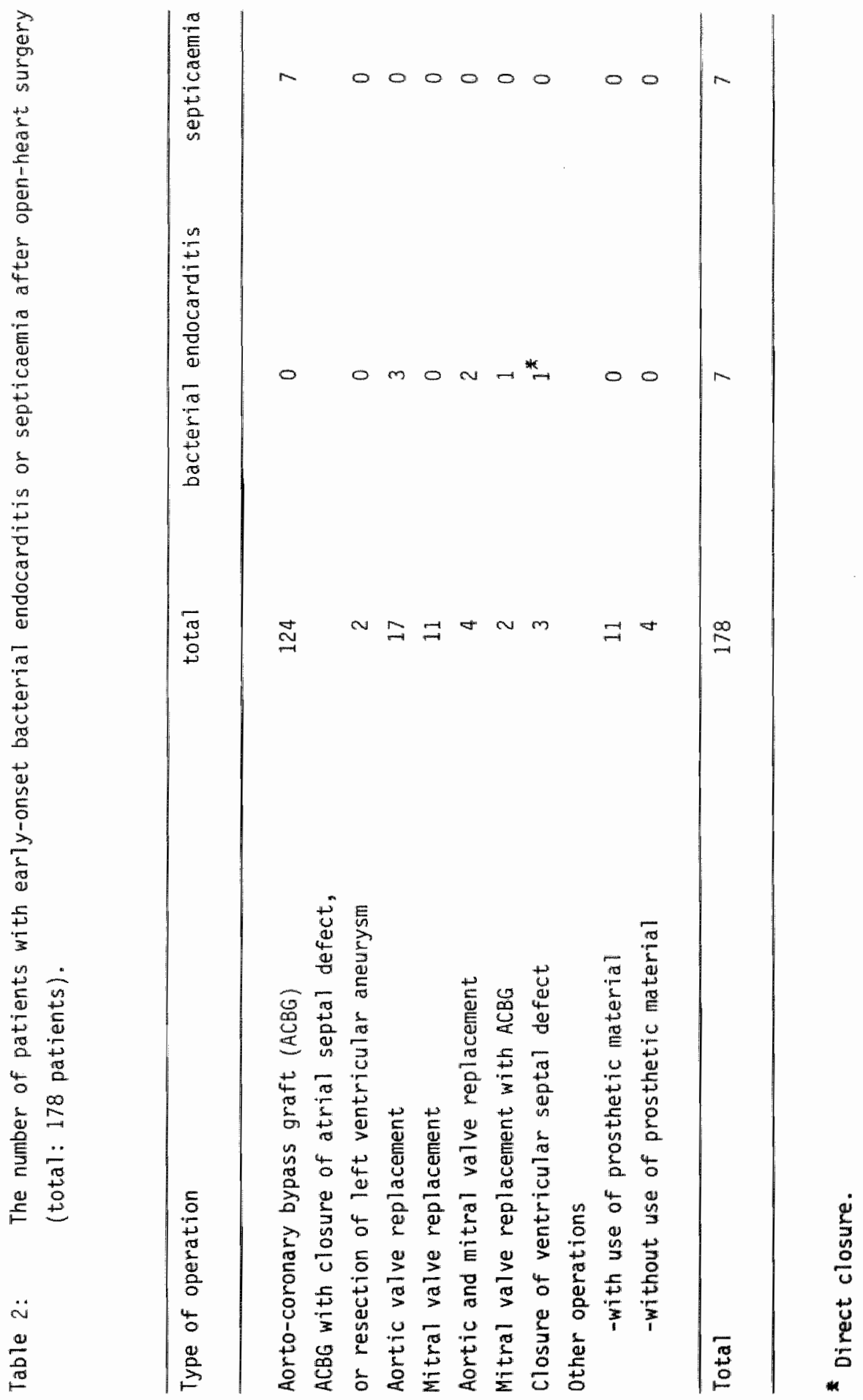




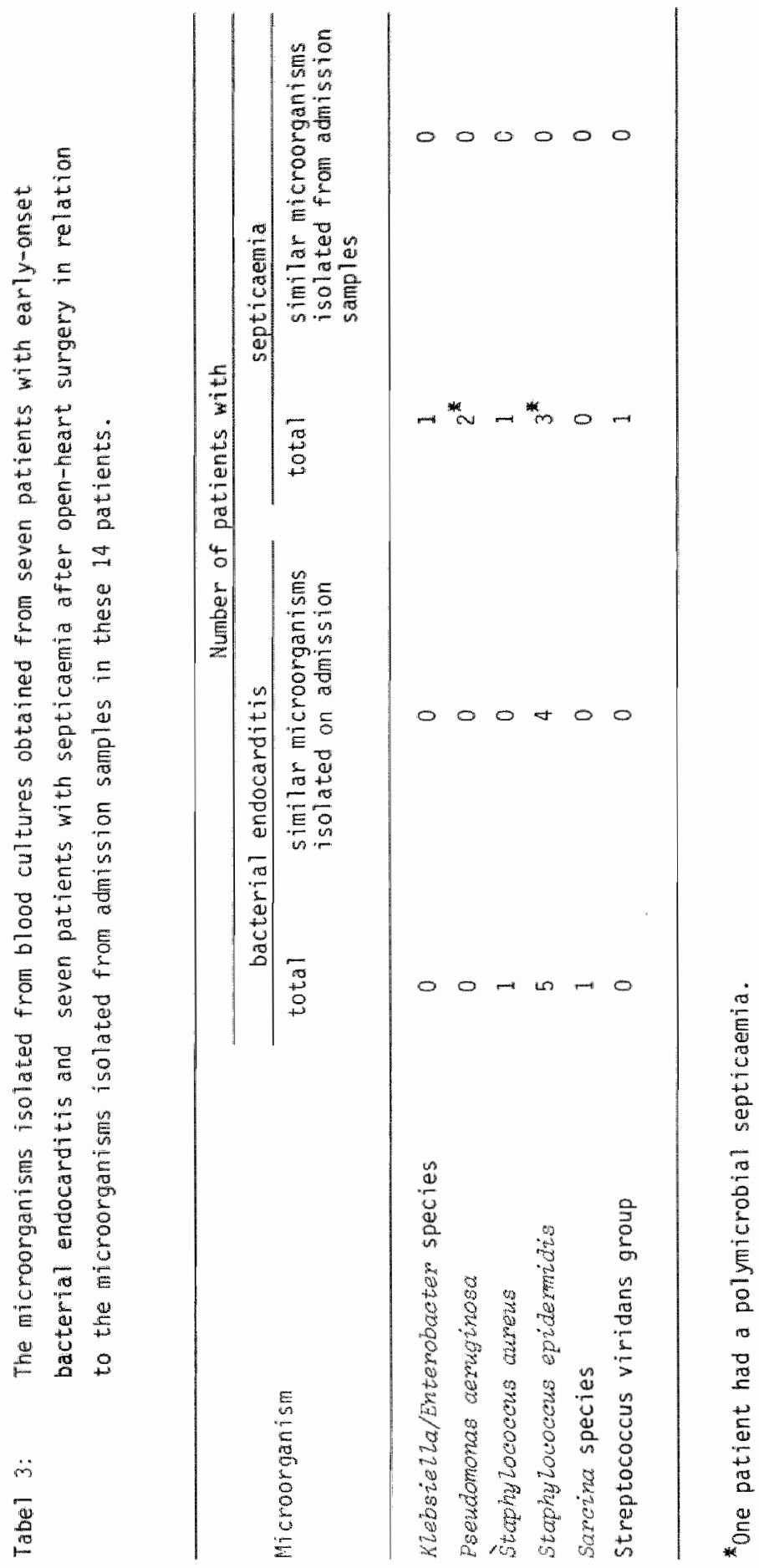


isolated from these patients at the time of admission.

In the study of the intravascular catheters the majority of the catheter tips was cultumed: from a total of 451 intravascular catheter tips the results were available. From 24 (5.3\%) tips derived from 23 patients, vamious microarganisms were isolated (table 4). None of the intracardiac catheter tip cultures showed growth, whereas five (3\%) cultures of the intra-arterial catheter tips and 19 (11\%) of the intravenous catheter tips were positive. The microorganism most often cultured was Staph.epidexmidis.

The mean duration of the catheter in place was not statistically significantly different in patients with positive intra-arterial catheter tips and patients with negative intra-arterial catheter tip cultures (Student $t$ test, $p=0.4$ ). Also no significant difference was found between the duration of intravenous catheters in place in patients with a positive tip culture compared to the duration of the intravenous catheter in place of patients with negative tip cultures (student $t$ test, $p=0.15$ ).

A relation between the microorganisms cultured from the intravascular catheter tips and from the samples taken on admission could be demonstrated in only a small number of the 17 patients with staph.epidermidis positive tip cultures (table 5). Antibiograms of six staph.epidemidis strains isolated from the tip cultures and from the skin flora were identical but biotyping revealed a similarity in only two of them. All six staph.epidermidis were non-typable using phage typing.

Bload cultures taken shortly ( $0-2$ days) after removal of the intravascular catheters were negative except in one case (table 5). In this patient Kzebsielza/Enterobacter species was cultured from the intraarterial as well as from the intravenous catheter tips and the blood sample. Later on a fatal septicaemia due to the same species occurred.

\subsubsection{LOWER RESPIRATORY TRACT INFECTION}

Lower respiratory tract infections occurred in $48(26.9 \%)$ open-heart surgery patients (table 6). The incidence of this infection was not signifïcantly different in patients undergoing an aarto-coronary bypass graft operation or in patients undergoing valve replacement surgery (chi square test $p=0.4$ ). Most of the positive sputum cultures were found an the first postoperative day: 28 out of the 48 specimens with growth. of the remaining 20 specimens, 14 were positive on the second, five on the third, and one on the fourth postoperative day. Forty cultures yielded growth 


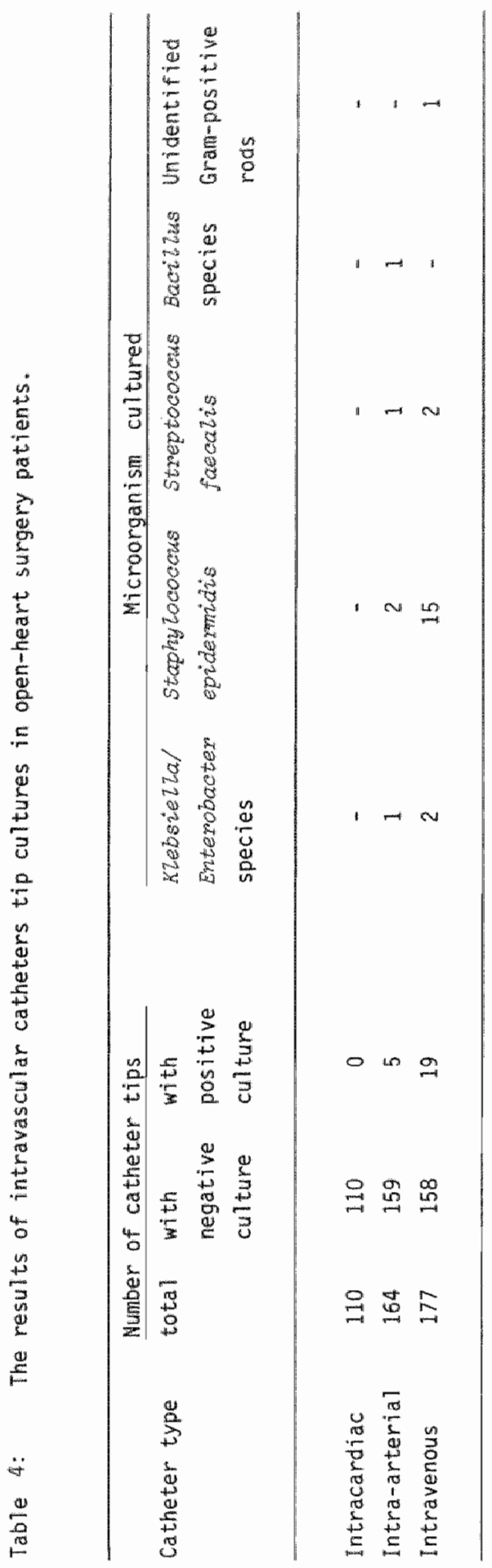




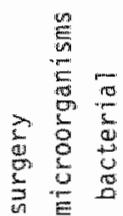

a

I.

总 $\frac{d}{\frac{6}{6}}$

w

등

4 is 8

总 营

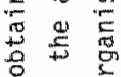

is 0

in w

$\therefore \equiv$

造造

骂焉要

10 d

उ in

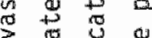

省

$=-45$

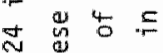

ह 5 क

4 해웡

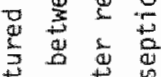

马 5 至

的莎焉署

동

E⿱

\&

E

E

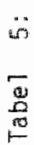

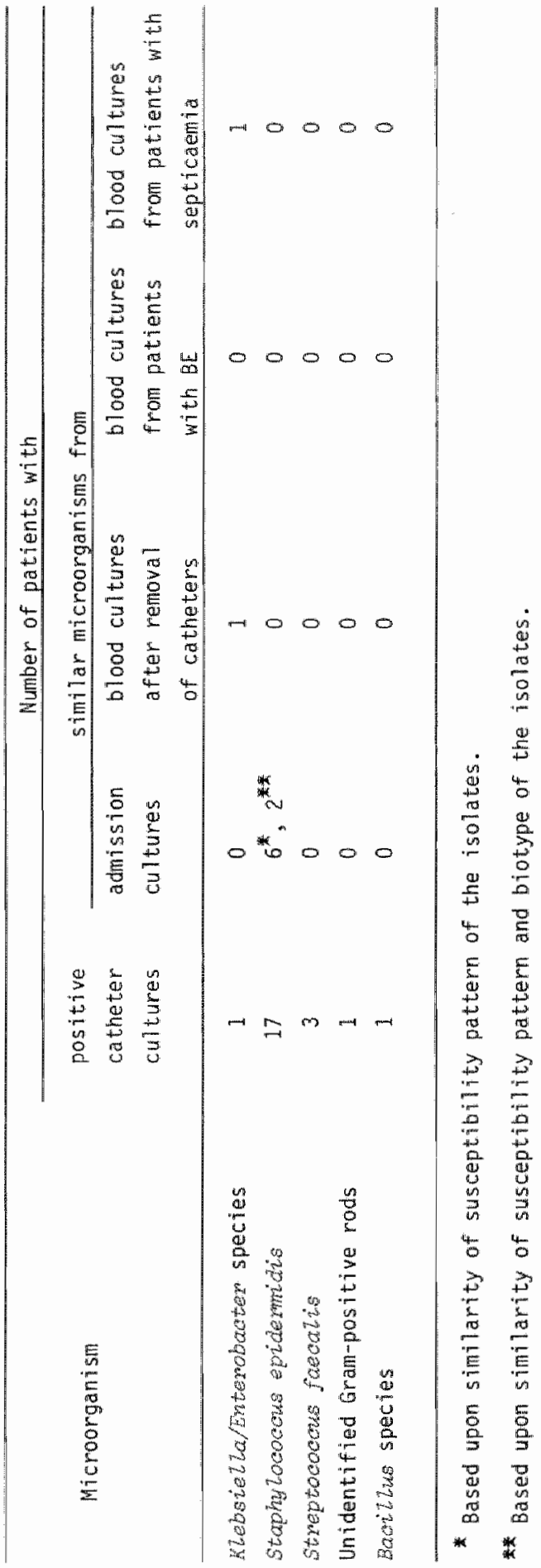




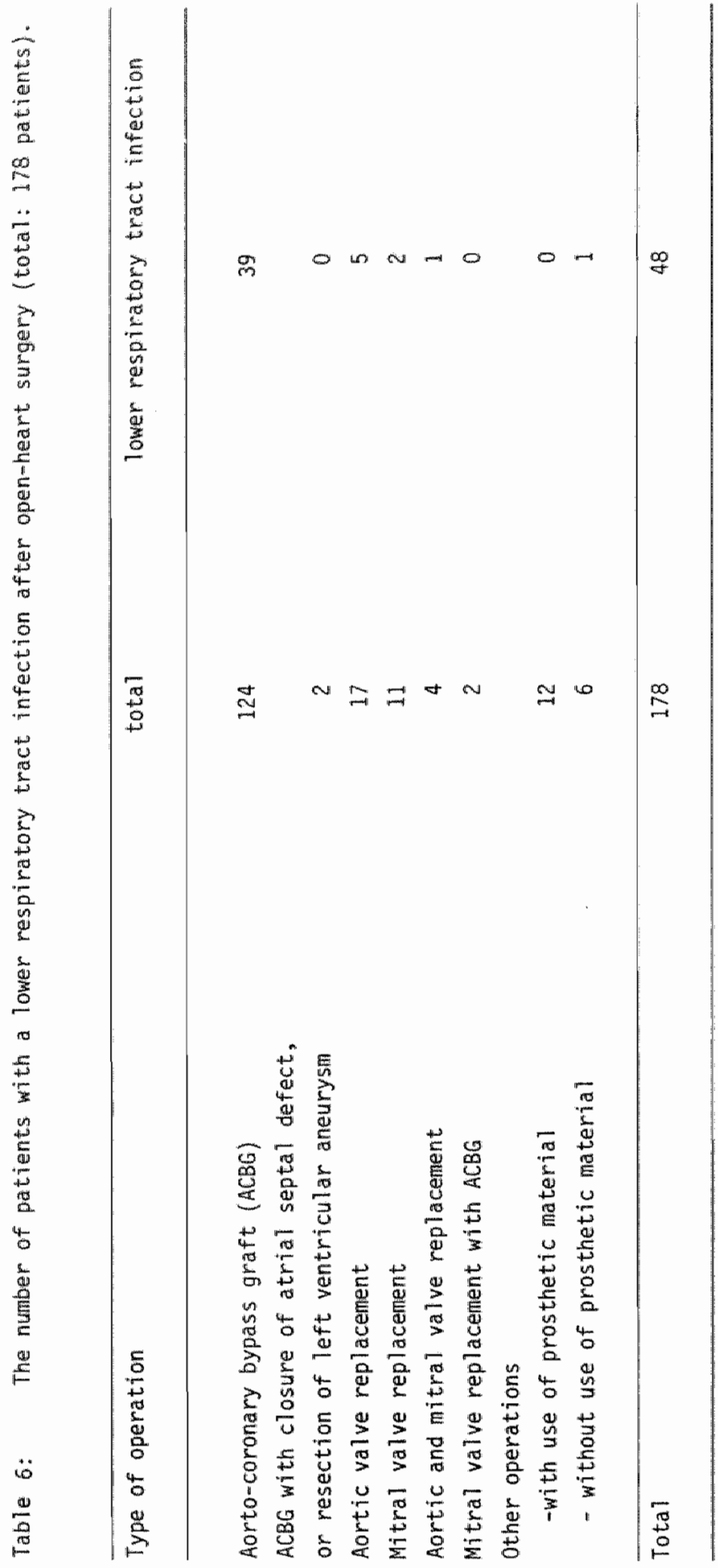


of one isolate, whereas eight contained two different microorganisms.

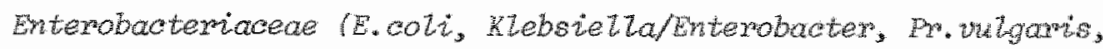
Serratia species) were the nost frequently encountered microorganisms (table 7). Streptococci were isolated from specimens obtained from seven patients and Candida abicans were isolated from specinens obtained from eight patients. Of all bacterial isolates only ten were resistant to cephalothin.

In 14 out of the 48 patients with a postoperative lower respiratory tract infection the isolated species were similar to those cultured from the admission flora (table 7). In six of these 14 patients the microorganisns isolated from the postoperative sputuru specimens were similar to those isolated from samples taken from the upper respiratory tract on admission. Admission samples from the perineum yielded similar species in ten of the 14 patients.

The relation between the culture results of the endotracheal tube tips and the occurrence of subsequent lower respiratory tract infection was a 1 so studied. Al1 161 endotracheal tubes from which the results of the tip cultures were available were removed on the first postoperative day, and 97 $(60.3 \%)$ tips revealed growth on culture. Mainly Enterobactemaceae and streptococci were isolated. In 33 of the 48 patients with a lower respliratory tract infection a similar microorganism was cultured from the endotracheal tube tip prior to the isolation from the sputum specimen. In 12 patients with a lower respiratory tract infection, the endotracheal tube tip cultures showed no growth of relevant beacteria.

\subsubsection{BACTERIURIA}

Postoperative bacteriuria was demonstrated in three patients (table 8 ). The urinary catheter was removed from all three patients one week before the onset of the bacteriuria. In the patient with a bacteriuria due to Pramimabizis this microorganism was not 1 solated from the samples taken on admission. In one patient the bacteriuria was due to 5 tr. faecalis, $E$. coli and Prominabilis. The latter two microorganisms were also isolated from perineum samples taken on admission. In another patient the bacteriuria was caused by a cephalothin resistant Citrobacter frezundi and E.coli. A similair E.coti was allso present on the perineum on admission.

The tips of at least 166 urinary tract catheters were cultured after removal of the catheter. Bacteria were 150 lated from $79(47.6 \%)$ of 


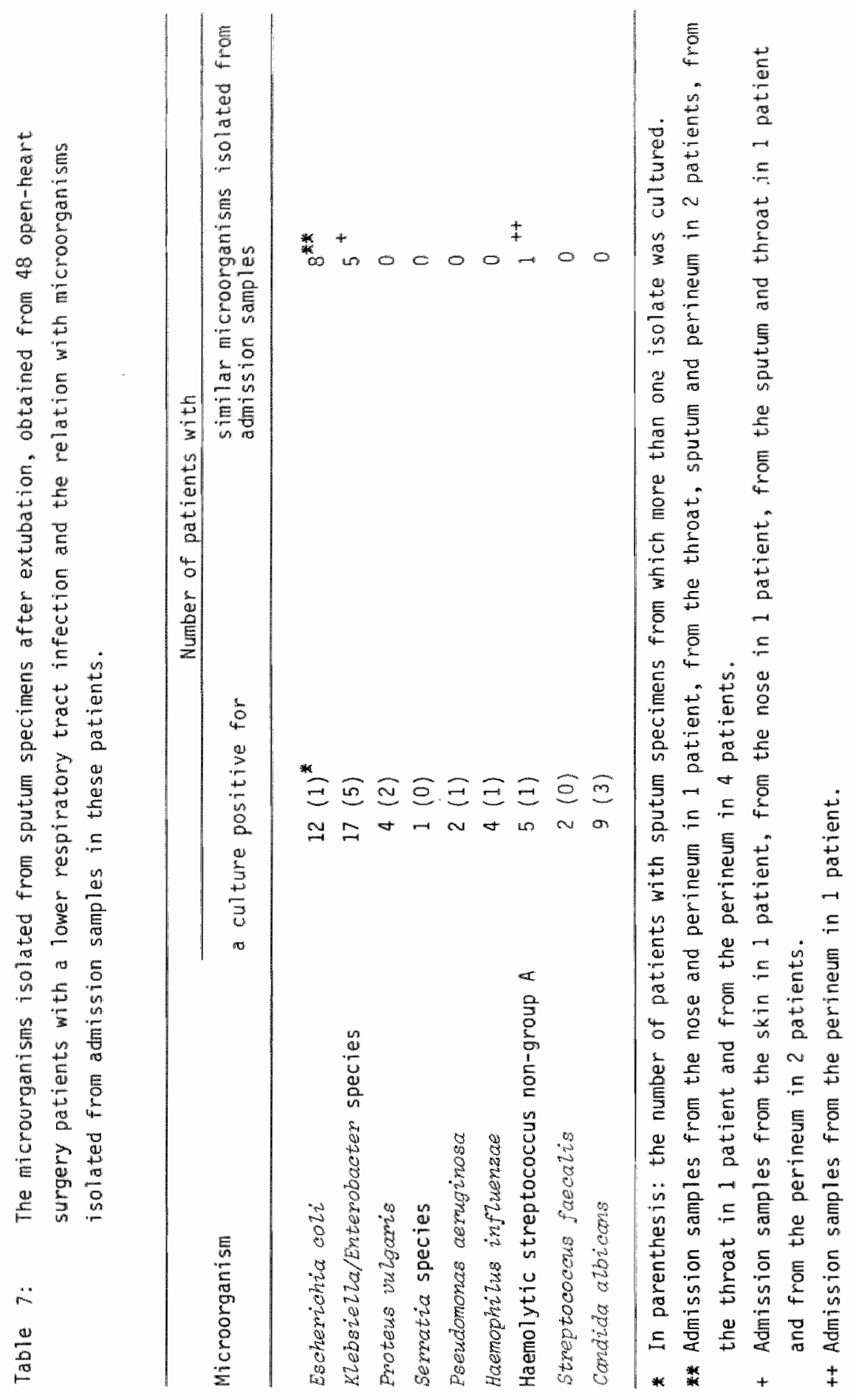




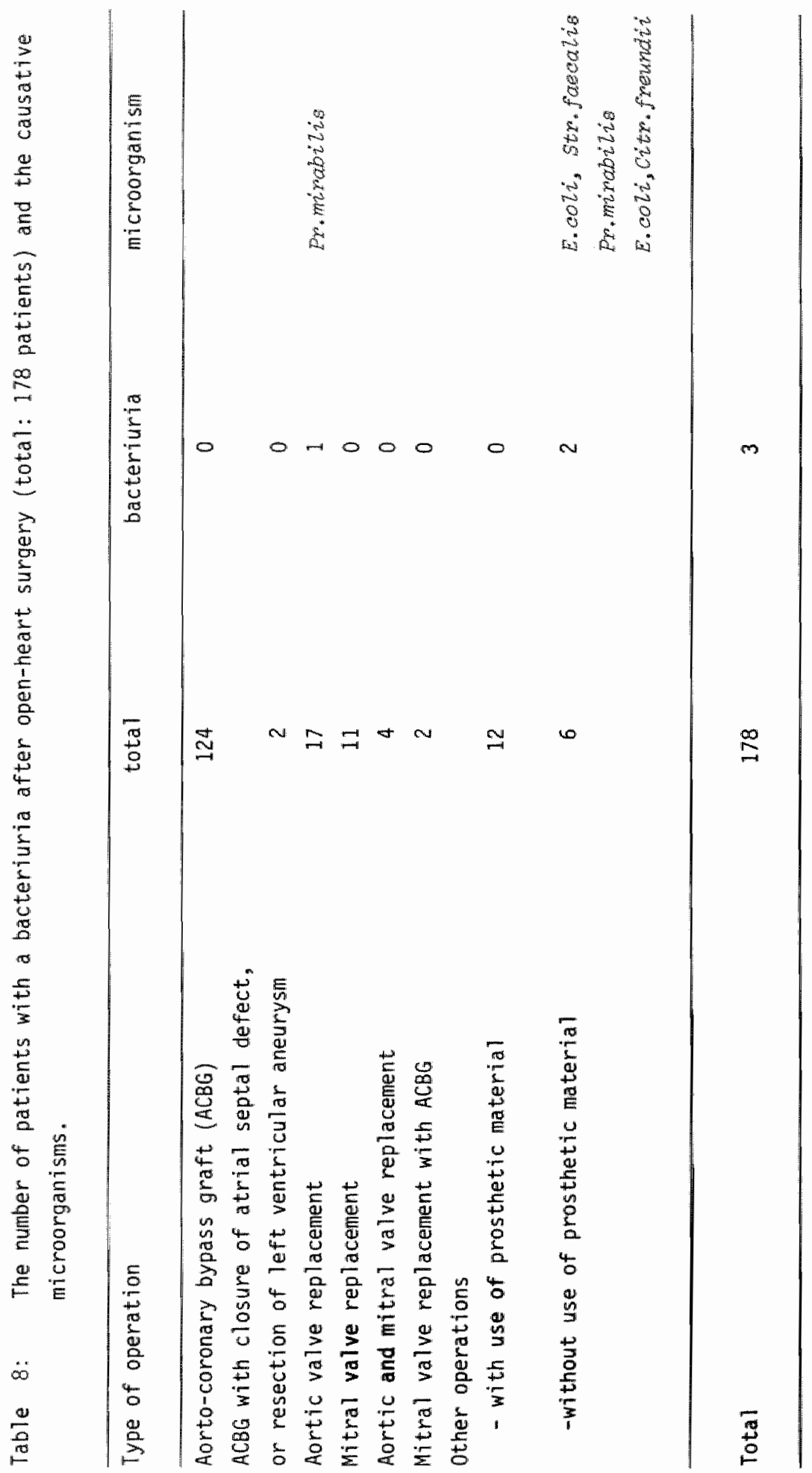




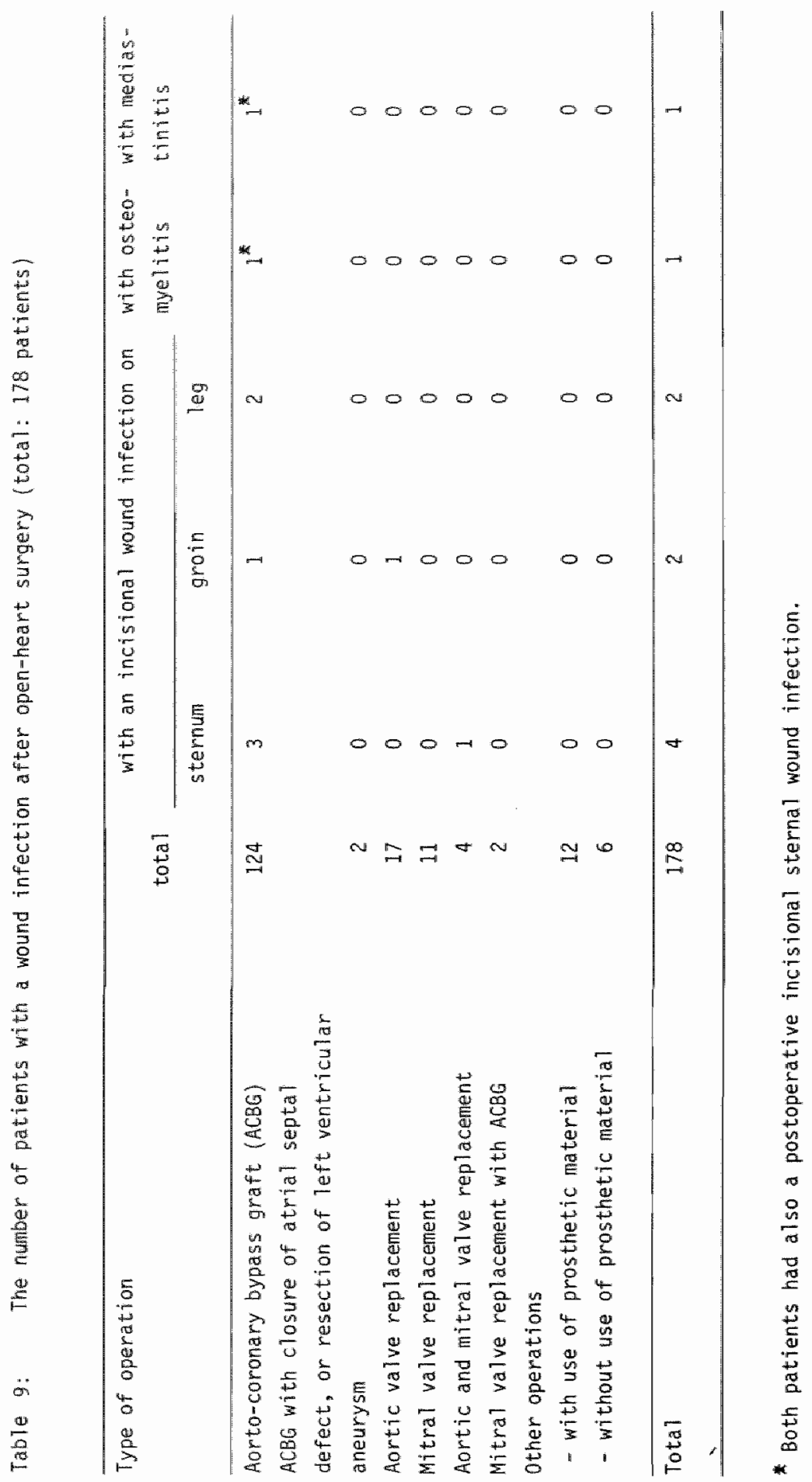




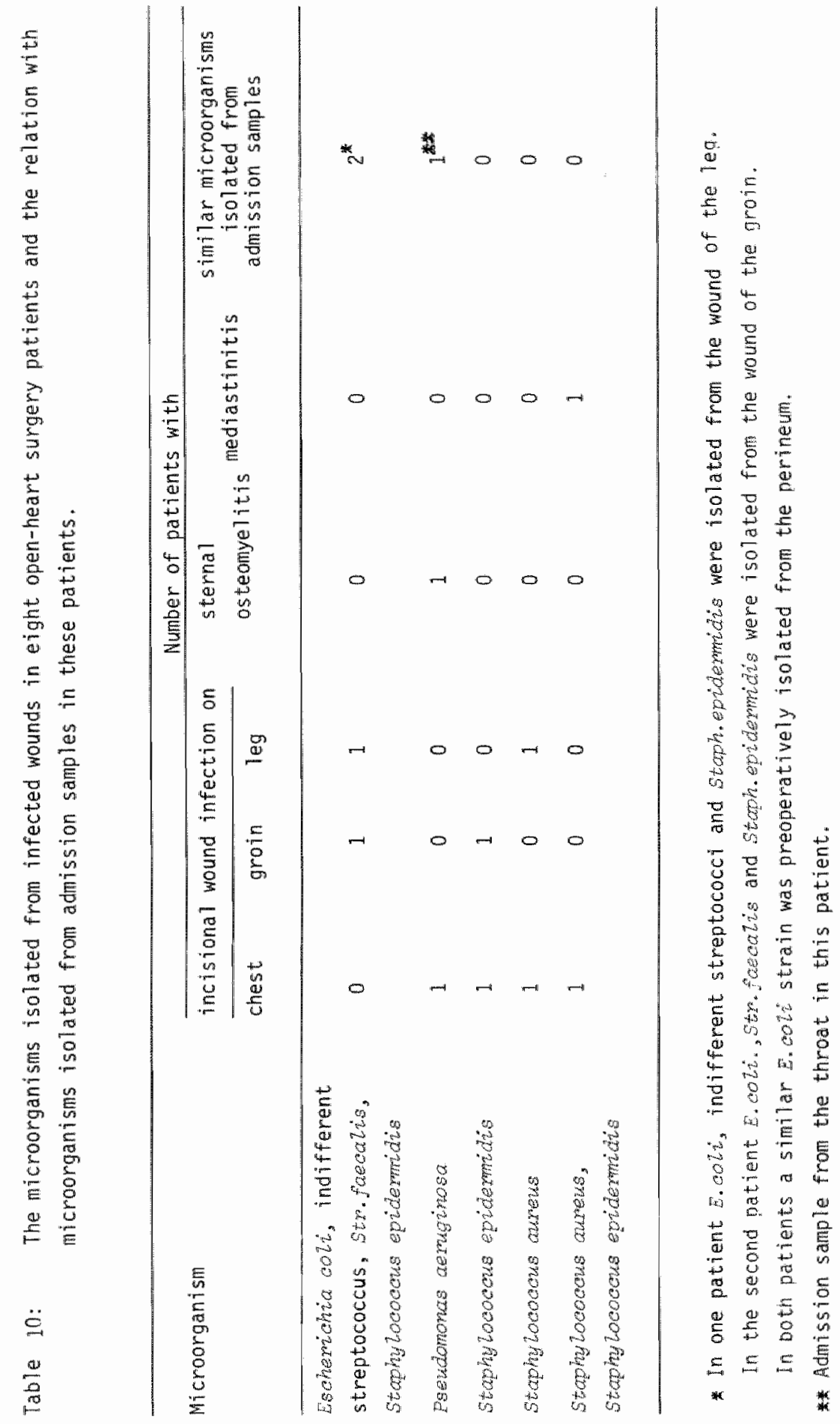


166 tips. The culture results of the remaining 12 tips were not available. In two cases microorganisms cultured from the tip were similar to those causing a subsequent bacteriuria.

\subsubsection{WOUND INFECTION}

Postoperative incisional wound infections occurred in eight (4.5\%) patients of whom four had an incisional sternal wound infection (tabie 9). Subsequentily one of these four patients had a sternal osteomyelitis and another patient had a sternal dehiscence together with a mediastinitis. Four patients had infections of the wound of the groin or the leg. Staphylococci, causing most of the wound infections (table 10) were sensitive for cephalothin, except in two cases. In two patients more than one microorganism was cultured from the infected wounds. Ps.caruginosa was the cause of an incisional sternal wound infection and of the subsequently occurring sternal osteomyelitis. Stoph.coureus and Staph. epidermidis were cultured from the pus obtained from the patient with a mediastinitis.

In three patients with a pastoperative wound infection, the same microorganisms had been isolated from wound samples and from samples from the perineum, skin or the throat on admission (table 10).

To see whether a positive wound drain tip could predict the occurrence of a postoperative wound infection, the tips of wound drains and the tips of thoracic drains were cultured. The culture results of wound and thoracic drain tips of 142 and 177 patients respectively, were available. Microorganisms were cultured from seven (4.9\%) wound drain tips, mainly staph.epidermidis. Ps.cemiginoed was cultured from one wound drain tip. In this patient a postoperative incisional sternal wound infection occurred, due to a similar strain. Deep wound infections could not be related to the presence of a positive thoracic drain tip culture. Thirteen (7.4\%) of the 177 thoracic drain tip cultures showed growth. Mainly Stoph.epidermidis were cultured but subsequent infections due to the anicroorganism did not occur.

\section{DISCUSSION}

The incidence of postoperative infections in 178 open- heart surgery 
patients was rather high. In total 75 postoperative infections ocurad in 63. (35\%) patients of whom 48 had a lower respiratory tract infection. Cephalothin, a first generation cephalosporin, was mainiy used as antimicrobial prophylaxis. Susceptibility testing of the microorganisms causing postoperative infections showed that about $70 \%$ of the isolates were sensitive for this antibiotic. Antimicrobial prophylaxis using cephalothin as the single antibiotic has been previousiy used in open-heart surgery patients. The incidence of postoperative infections in patients who prophylactically received cephalothin has been reported (21-24). In these four reports, a total of 442 patients was involved. Analysis of the postoperative infections in these 442 patients showed that bacterial endocarditis occurred in one $(0.2 \%)$ patient, bacteraemia in ten (2.3\%) patients, lower respiratory tract infections in $30(6.8 \%)$ patients, wound infections in 21 (4.8\%) patients and bacteriuria in $43(9.7 \%)$ patients. Comparing these incidences of infection with those found in our study, similar percentages for bacteraemia and wound infection were found. The incidences of the ather infections differed markedly. Early-onset bacterial endocarditis was present in $3.9 \%$ of the patients in our study. The incidence of lower respiratory tract infections in our patients was almost four times higher. Bacteriuria occurred less frequently in our patients $(1.7 \%)$.

The question can be raised if this comparison is a valid one since the incidences of each infection in the patients from the four different reports varied markedly and the patients involved belonged to different risk categories. Moreover, appropriate definitions of the infections were given in only two of the reports $(22,24)$.

The relatively high incidence of lower respiratory tract infections in our patients might be partly due to the diagnostic criteria of a lower respiratory tract infection used in this study.

An incidence of $3.9 \%$ of early-onset bacterial endocarditis among the patients in our study is high, especially if the number of patients most at risk for prosthetic endocarditis, mamely 47 patients with surgical prostheses. are taken into account.

six of the seven cases with bacterial endocarditis were caused by staph.epidermidis and staph. aureus strains, all subjected to typing procedures. In four cases staph.eptidermidis was probably derived from patients' own admission flora. The onset of the infection (mean onset: 12 days after operation) suggests that these strains gained access into the blood stream during or after operation. 
We have not perfomed assays to determine the cephalothin serum level. However, it is known that the serum cephalothin level during extra corporeal circulation is rather high when two gram of this antibiotic is admitistered just prior to cardiopulmonary bypass (25). Therefore the incidence of early-onset bacterial endocarditis is remarkably high since the microorganisms causing early-onset bacterial endocarditis were sensitive for this antibiotic. This means that contamination of the blood stream after surgery has to be taken into account, although no evidence is avallable.

Postoperative septicaemia's only occurred after aorto-coronary bypass graft operations and were caused by various microorganisms. The microorganisms involved were probably derived from exogenous sources since none of the microorganisms were cultured from samples taken from the patients on admission.

Postoperative wound infections were mainly caused by Gram-positive microorganisms whereas lower respiratory tract infections and bacteriuria"s were mainly caused by Gram-negative microorganisms.

A possible relation between the microorganisms cultured preoperatively from the patients on the day of admission, and those causing postoperative infections was demonstrated in only about one third of the infections. Routinely performed culture procedures $(1,4,5,21,23,26)$ are seldom thoroughly tested on their merits. Although cooper et al. (26) also concluded from their data that the results of a preoperative bacteriological screening did not predict the occurrence of a postaperative infection, they have not defined the similarity of isolates. Comparing the microorganisms causing postoperative infections with those isolated from preoperative cultures, Frater and santos (5) found a relation in only $21 \%$ of their infected patients. In another study (4) preoperative culture results were used to abtain insight into the frequency of postoperative acquisition of Gran-negative microorganisms. Typing of the microorganisms was not performed in any of these situdies.

In our study stoph.epidemidis ilsolates were biotyped and phage typed and staph aureus isolates were phage typed. All isolates were tested for antimicrobial susceptibility. The susceptibility pattern, commonly referred to as antibiogram, was used, besides for clinical purposes, to determine a relation between the isolates. The antibiogram can be used as an epidemiological tool (27). However, the method has its limitations (28). Susceptibility to antibiotics is not a stable genetic property. It may be infiluenced by enviromental conditions and by plasmids (27). The results of the phage 
typing of Stoph.epidemidis were disappointing and confimed the inadequacy of the phage typing method, as reported previously (20). Themefore a relation between staph. epidemizis isolates from the admission flora and the occurrence of infections caused by this microorganism and the presence of Stoph.epidemidis on intravascuiar devices was based on the results obtained by comparison of their biotypes and of their antibiograms. Four out of five cases of postoperative early-onset bacterial endocarditis were caused by staph.epidermidz:s strains identical to those present in the admission flora. In contrast septicaemia due to staph. epidermidis was probably caused in all three cases by strains from exogenous sources. Only a small number of the staph.eptidermidis isolates cultured from intravascular catheter tips appeared to be identical to staph.epidemidis isolated from the admission flora. Infections due to staph.aureus occurred in four patients who al1 had staph. curreus negative samples on admission, suggesting that these infections were due to strains acquired in the hospital. In the case of the other isolates causing postoperative infections the results of pre- and postoperative culluring were compared and if the same species were isolated pre- and postoperatively, the antibiognams of the isolates were compared. Similar isolates were found in about one third of the infections.

Cullturing indwelling devices, such as intravascular catheters, urinary catheters and wound and thoracic drains was also unable to predict the occurrence of septicaemia, bacteriuria or wound infections. However, $69 \%$ of lower respiratory tract infections were caused by microorganisms similar to those cultured from the endotracheal tube tips prior to the onset of this infection.

Dur results indicate that the preoperative bacteriological surveillance of open-heart surgery patients perfomed routinely on the day of admission, had only a small predictive value towards the occurrence of postoperative infections. Such surveillance can be useful for epidemiological studies to gain insight into the various sources of contamination. Another reason for taking preoperative samples from open-heart surgery patients is the need to be informed about the susceptibility or the resistance of microorganisms cultured from the endogenous flora. The results of preoperative sampling will provide data on which the prophylactic antimicrobial regimen can be adjusted (29). 


\section{REFERENCES}

1. Goodmian, J.S., Schaffner, H., Collins, H.A., Battersby, E.J. and Koenig, M.G. Infection after cardiovascular surgery. Clinical study including examination of antimicrobial prophylaxis. New. Engl.J.Med. 278:117,1968.

2. Watanakunakorn, C. Prosthetic valve infective endocarditis. Prog. Cardiovasc. Dis. 22:181,1979.

3. Hornick, R.B. Source of contamination in open-heart surgery. In: R.J.Duma, ed. Infections of prosthetic heart valves and vascular grafts. Baltimore: University Park Press, 1977; 81.

4. Rosendorf, L.L., Daicoff, G. and Baer, H. Sources of Gram-negative infection after open-heart surgery. J.Thorac.Cardiovasc.Surg.

67: 195,1974 .

5. Frater, R.W.M. and Santos, G.H. Sources of infection in open-heart surgery. N.Y. State J.Med. $74: 2386,1974$.

6. Norenberg, R.G., Sethi, G.K., Scott, S.M. and Takaro, T. opportunistic endocarditis following open-heart surgery. Ann. Thorac. Surg. 19: 592, 1975.

7. Carey, J.S. and Hughes, R.K. Control of infection after thoracic and cardiovascular surgery. Ann. Surg. 172: 916,1970.

8. Blakemore, W.S., Mc. Garrity, G.J., Thurer, R.J., Wallace, H.W., Mac Vaugh, H. III and Coriell, L.L. Infection by air-borne bacteria with cardiopulmonary bypass. Surgery $70: 830,1971$.

9. Kluge, R.M., Calia, F.M., McLaughlin, J.S. and Hornick, R.B.Sources of contamination in open-heart surgery. JAMA 230:1415,1974.

10. Clark, R.E., Amos, W.C., Higgins, V., Bemberg, K.F. and Weldon, C.S. Infection control in cardiac surgery. Surgery $79: 89,1976$. 
11. Stein, P.D., Harken, D.E. and Dexter, L. The nature and prevention of prosthetic valve endocarditis. Am. Heart J. 71: 393,1966.

12. Dismukes, W.E., Karchmer, A.W., Buckley, M.J., Austen, W.G. and Swartz, M.N. Prosthetic valve endocarditis. Analysis of 38 cases. Circulation. 48: 365,1973 .

13. Dismukes, W.E. and Karchmer, A.W. The diagnosis of infected prosthetic heart valves: bacteremia versus endocarditis. In: R.J.Duma, ed. Infections of prosthetic heart valves and vascular grafts. Baltimore: University Park Press, 1977; 61.

14. Wilson, W.R. Prosthetic valve endocarditis: incidence, anatomic location, cause, morbidity and mortality. In: R.J. Duma, ed. Infections of prosthetic heart valves and vascular grafts. Baltimore: University Park Press, 1977; 3.

15. Black, P.C., DeSanctis, R.W., Weinberg, A.N. and Austen, W.G. Prosthetic valve endocarditis. J.thorac.Cardiovasc.Surg. 60: 540,1970.

16. Bagshawe, K.D., Blowers, R. and Lidwel1, 0.M. Isolating patients in hospital to control infection. Part I. Sources and routes of infection. Br. Med. J. 2: 609,1978 .

17. Maki, D.G. Control of colonization and transmission of pathogenic bacteria in the hospital. Ann. Int. Med. 89 (part II): 777, 1978.

18. Baffes, T.G., Blazek, W.V., Fridman, J.L., Agustsson, M.H. and van Elk, J. Postoperative infections in 1,136 consecutive cardfac operations. Surgery 68: 791,1970 .

19. Levenson, S.M. and Laufman, H. Infection hazard of surgical intensive care: isolation procedures in the surgical intensive care unit. In: J.M.Kinney, H.H. Bendixen and S.R. Powers, eds. Manual of surgical intensive care. Philadelphia: W.B. Saunders Comp. 1977; 151. 
20. Staal, M.J., Stobberingh, E.E. Haverkorn, M.J. and van Boven, C.P.A. Application of phage-typing and biotyping to the epidemiology of coagulase-negative Staphylococci in cardiovascullar surgery. In: J. Jeljaszew $1 \mathrm{cz}$, ed. Staphylococci and Staphylococcal infections. Proceedings of IV international symposium on Staphylococci and Staphylococcal infections. Zb1. Bakt. Supp1. 10. Stuttgart-New York: Gustav Fischer Verlag, 1981; 189.

21. Conte, J.E. Jr., Cohen, S.N., Roe, B.B. and Elashoff, R.M. Antiblotic prophylaxis and cardiac surgery. A prospective double-blind comparison of single-dose versus multiple-dose regimens. Ann. Int. Med. 76: 943,1972 .

22. Goldmann, D.A., Hopkins, C.C., Karchmer, A.W., Abel, R.M., Mc.Enany, M.T., Akins, C., Buckley, M.J. and Moellering, R.C., Jr. Cephalothin prophylaxis in cardiac walve surgery. A prospective double-blind comparison of two-day and six-day regimens. J. Thorac. Cardiovasc.Surg. $73: 470,1977$.

23. Kini, P.M., Fernandez, M.D. , Causay, R.S. and Lemole, G.M. Double-blind comparison of cefazolin and cephalothin in open-heart surgery. J.Thorac. Cardiovasc.Surg. 76: 506, 1978.

24. Pien, F.D., Michae1, N.L., Mamiya, R., Pakaki, H., Slavish, S., Bruce, A. and Moreno-Cabral, R.J. Comparative study of prophylactic antibiotics in cardiac surgery. Clindamycin wersus cephalothin. J. Thorac Cardiovasc. surg. $77: 908,7979$.

25. Miller K.W.. Chan, K.K.H., McCoy, H.G., Fisher, R.P. , Lindsay, W.G., and Zaske, D.E. Cephalothin kinetics: Before, during, and after cardiopulmonary bypass surgery. Clin. Phamacol. Ther. 26: 54,1979.

26. Cooper, D.K.C., Norton, R., Mobin, M.A., Cleland, W.P., Benta11, H.H. and Darrell, U.H. A comparison of two prophylactic antibiotic regimes for open-heart surgery. J.Cardiovasc.Surg.21: 279, 1980.

27. Aber, R.C. and Macke1, D.C. Epidemiologic typing of nosocomial microorganisms. Am. al. Med. $70: 899,1981$. 
28. Goldmann, D. Laboratory procedures for infection control. In: E.H.Lennette, A.Balows, W.J. Hausler, Jr., and Truant, J.D., eds. Manual of clinical microbiology. $3^{\mathrm{d}}$ ed. Washington, $0 . \mathrm{C}$. : American Society for Microbiology, 1980; 939.

29. Newson, S.W.B. Antibiotic prophylaxis for open-heart surgery. J. Antimicrob. Chemother. 4: 389,1978 . 
CHAPTER IV

DETECTION AND TREATMENT OF STAPHYLOCOCCUS AUREUS CARRIAGE IN RELATION TO THE OCCURRENCE OF POSTOPERATIVE STAPHYLOCOCCUS AUREUIS INFECTIONS 


\section{INTRODUCTION}

A relation between the preoperative carriage of stophyzococcus aureus in the nose of patients and the occurrence of postoperative wound infections has been reported (1-6). In patients who underwent thoracic surgery (7-9) or (open-) heart surgery $(8,9)$, attention has also been drawn to the greater frequency of postoperative staph. atreus infections amang stoph. awreus carriers. It was suggested therefore that preoperative treatment of staph. careus nasal carriers would reduce the incidence of postoperative wound infection caused by staph.cuseus (2). Although the stoph. ourews carriers had a higher sepsis rate than non-carriers and the nasal carriage was reduced to a large extent after treatment, Henderson and Williams (2) could not demonstrate a reduction in the postoperative wound infection rates among the stoph. aumeus nasal carriers who were treated preoperatively with nasal antimicrobial ointment when compared to a control group of un-treated stoph. cureus carriers. They suggested that this could be due to an inefficient swabbing technique or due to a variability of the presence of staph. aureus in the nasal flora.

In this study, the reliability of the sampling method for detection of nasal and pharyngeal carriage of Staph. aureus and the persistence of this carriage in patients and hospital personnel was investigated. In addition the effect of the preoperative treatment of nasal carriers among patients on the occurrence of postoperative infections due to stoph. aureus was studied.

\section{SUBJECTS AND METHODS}

\subsection{PREOPERATIVE SAMPLING OF PATIENTS, TREATMENT DF NASAL CARRIERS AND POSTOPERATIVE INFECTIONS}

Samples from the nose, throat, several sites of the skin and the perineum were taken on the day of admission from 182 patients admitted for open-heart surgery, using dry cotton-tipped swabs. Both vestibules of the nose were sampled using one swab. The swab was rotated during sampling. The throat was sampled by rubbing the pharyngeal mucosa of the left and right pharyngeal wall between the two pharyngeal arches with one swab. The sites of the skin and the perineun were sampled by streaking twice a surface of approximately $4 \mathrm{~cm}^{2}$, using one swab for each place.

Chlorhexidin digluconate $(0.5 \% \mathrm{w} / \mathrm{w})$ ointment was applied to the nasal 
mucosa of 34 randomly selected patients with stcoph. aureus positive nasal swabs.

Postoperative infections due to Staph. aureus were recorded prospectively according to the definitions given in Chapter II.

\subsection{ACCURACY OF THE SAMPLING METHOD AND THE PERSISTENCE OF PREOPERATIVE} STAPH. AUREUS CARRIAGE IN PATIENTS AND HOSPITAL EMPLOYEES.

In order to determine the accuracy of the swabbing technique employed to detect nasal and pharyngeal carriage of staph.oureus, samples from these two sites were taken twice from 89 patients and from a group of 183 hospital employees (initial examination). This group consisted of 31 ward nurses and doctors, 48 laboratory technicians, 47 members of the operating room staff, 15 physiatherapists and 42 student nurses.

The persistence of the carriage of Stcophomeus on the nasal and pharyngeal mucosa was studied in the same 89 patients and 183 hospital employees by re-sampling once the nose and pharynx (follow up examination). The results of these samples were compared to the results of the first sanples of the initial examination. The mean interval between the initial examination and the follow up examination was two days (range: 1-3 days) for the patients and seven days (range: 5-9 days) for the hospital employees. Those who used antimicrobial agents in the three weeks preceeding the initial examination or during the follow up period and those with an infection of the upper respiratory tract, were excluded from the study.

\subsection{CULTURE METHODS, SUSCEPTIBILITY TESTING, PHAGETYPING AND STATISTICS.}

Culture methods, susceptibility testing and phagetyping are described in Chapter III. All Staph.aureus strains were phage typed. The results were subjected to statistical analysis, using the chi square test on two observed grouped distributions. 


\subsection{THE PREOPERATIVE PRESENCE OF STAPR. AUREUS AND THE OCCURRENCE OF POSTOPERATIVE INFECTIONS.}

of 182 patients admitted for open-heart surgery, Stoph.coureus was cultured from 65 (36\%) patients of whom 56 had a staph.coureus positive nasal swab (table 1). In 21 patients, this microorganism was also isolated from one of the other sites sampled. In nine patients, nasal swabs were negative but Stcoph. oureus was present in the throat of eight patients and on the skin of one patient. In seven patients, Staph.oureus was isolated from the perineum, but samples taken from other sample sites including the nose were also Staph.cureus positive.

Thirty four out of 56 patients with a Stoph. ouxeus positive nasal swab were treated with the chlorhexidin containing ointment. Staph. caureus infections did not occur in treated or in un-treated stoph. curreus positive patients (table 2).

Six postoperative infections due to staph.aureus occurred in four patients who were stcoph.oureus negative or admission (table 2). Two patients had a wound infection and one had an early-onset bacterial endocarditis. A fourth patient had an incisional wound infection, a mediastinitis and a septicaemia. A common source of these infections was not likely as the phage types of the isolated strains differed per patient.

\subsection{ACCURACY OF THE SAMPLING METHOD AND THE PERSISTENCE OF PREOPERATIVE STAPH. AUREUS CARRIAGE IN PATIENTS.}

The results of the first nasal cultures showed that Staph. aureus was isolated from $33(37 \%)$ of the 89 patients (table 3 ). The second sample, taken immediately after the first one, yielded staph.coureus in three additional patients. This means that a total of $36(40 \%)$ patients had Stoph. atreus in their nose at the time of admission. Two consecutive samples taken from the throat revealed the presence of staph.cureus in 18 (20\%) patfents whilst sampling once showed Stcph.cureus to be present in 15 (17\%) patients (table 3 ).

The results of the first sample obtained at the initial examination, were used to determine the persistence of staph. aureus in the nasal and throat flora. The results of the follow up examination of the nasal flora 
Table 1: The preoperative isolation of stoph. aureus from 182 patients.

\begin{tabular}{lc}
\hline Site & Number of patients $(\%)$ \\
\hline Nose & $35(19.3)$ \\
Throat & $8(4.4)$ \\
Skin & $1(0.6)$ \\
Perineum & 0 \\
Nose + throat & $7(3.9)$ \\
Nose + skin & $4(2.2)$ \\
Nose + perineum & $2(1.1)$ \\
Nose + throat + skin & $3(1.7)$ \\
Nose + throat + perineum & $1(0.6)$ \\
Nose + skin + perineum & $4(2.2)$ \\
None & $117(64.3)$ \\
& \\
\hline Total & $182(100.0)$ \\
\hline
\end{tabular}




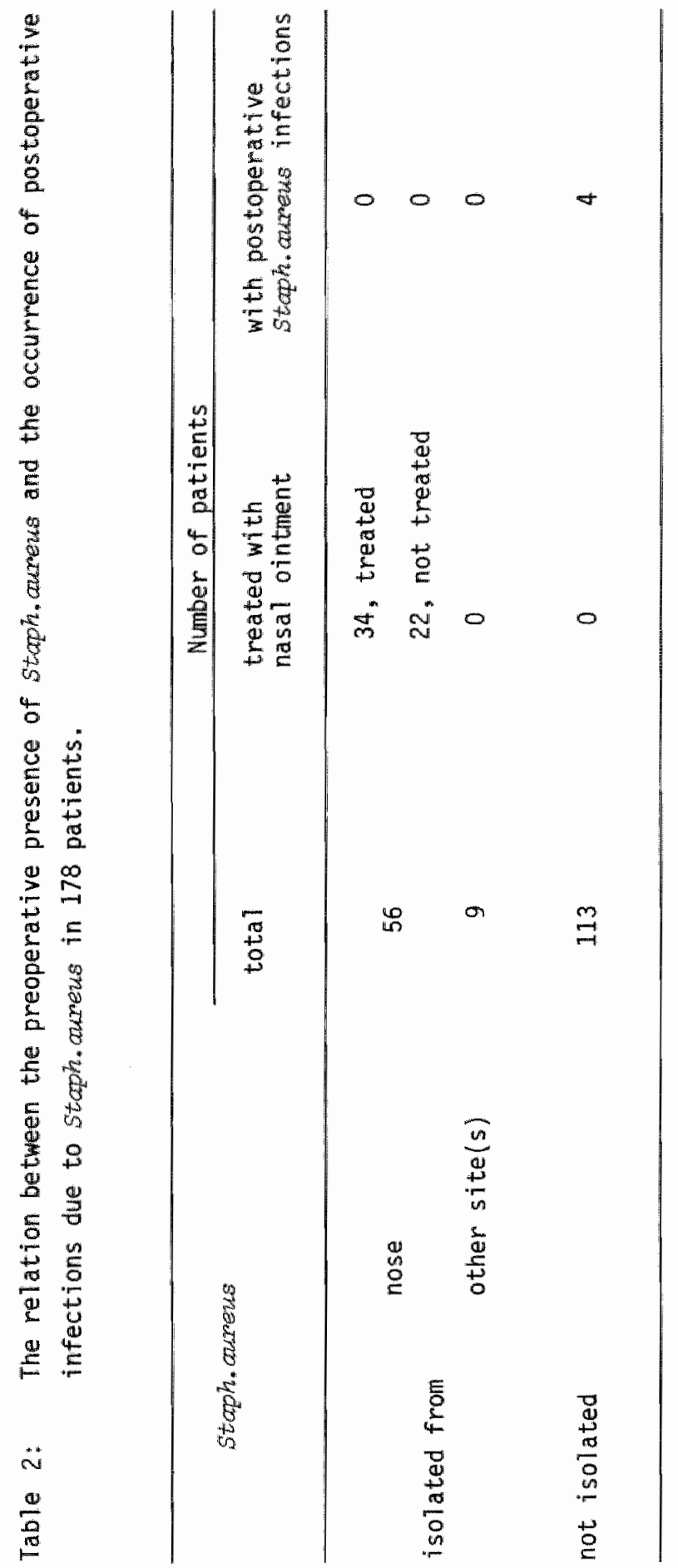




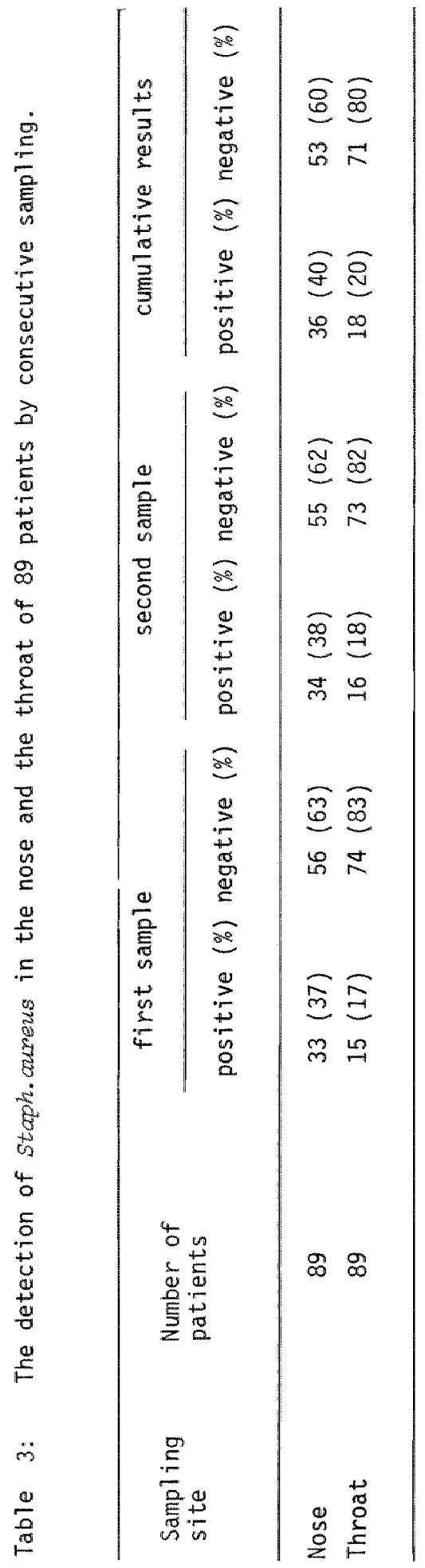


perfomed two days later, showed that seven (21\%) out of 33 patients with Btaph. oureus in their nose at the initial examination became negative (table 4). Persistence was found in 26 (79\%) of the initially staph.aureas positive patients. However the phagetype of 5 toph. oureus from at least three patients differed from the phagetype of the stoph.caureus isolated at the inttial examination. Three (5\%) out of 56 patients initially negative, were positive at the follow up examination. The results of the follow up examination of the throat flora, two days after the initial examination, showed that seven ( $47 \%$ ) out of 15 patients positive at the initial examination, became negative (table 4). Phage typing revealed that at least two out of eight patients had another strain than at the initial examination. of the 74 initially staph.aureus negative patients, 14 (19\%) became staph. aurewa positive at the follow up examination.

\subsection{ACCURACY OF THE SAMPLING METHOD AND THE PERSISTENCE DF STAPH.AUREUS CARRIAGE IN HOSPITAL EMPLOYEES.}

The results of the first nasal cuitures of the initial examination showed that Staph.aureus was isolated in 64 (35\%) of 183 employees (table 5). The highest percentage was among the ward nurses $(48 \%)$. The lowest percentage was among the physio-therapists $(20 \%)$. The differences between the various categories were not significant $(p=0.4)$. Staphicaureus was present in the throat flora of $20 \%$ of the employees (table 5). Laboratory technicians showed the highest percentage (27\%) whereas the lowest percentage was found among the ward nurses. No statistically significant difference was seem among the various categories $(p=0.4)$. The consecutive second nasal culture yielded Stoph.oureus in 67 (37\%) employees (table 6). Accumulation of the results of the samples showed that $S t a p h$. cumeus was isolated from the nasal flora of 71 (39\%) hospital employees. The results of both cultures taken from the throat showed that $45(25 \%)$ employees were staph. aureus positive (table 5 ). At the initial examination this microorganism was detected in $36(20 \%)$ of them.

The follow up examination of the nasal flora of 174 hospital employees, performed seven days after the initial examination showed that 56 (32\%) were staph. aurews positive (table 7). Comparison between the results obtained at the follow up examination and the initial examination showed that 11 (19\%) out of 59 employees who were initially positive, became negative.

Staph. aureus isolated from at least eight of the 48 employees who were 


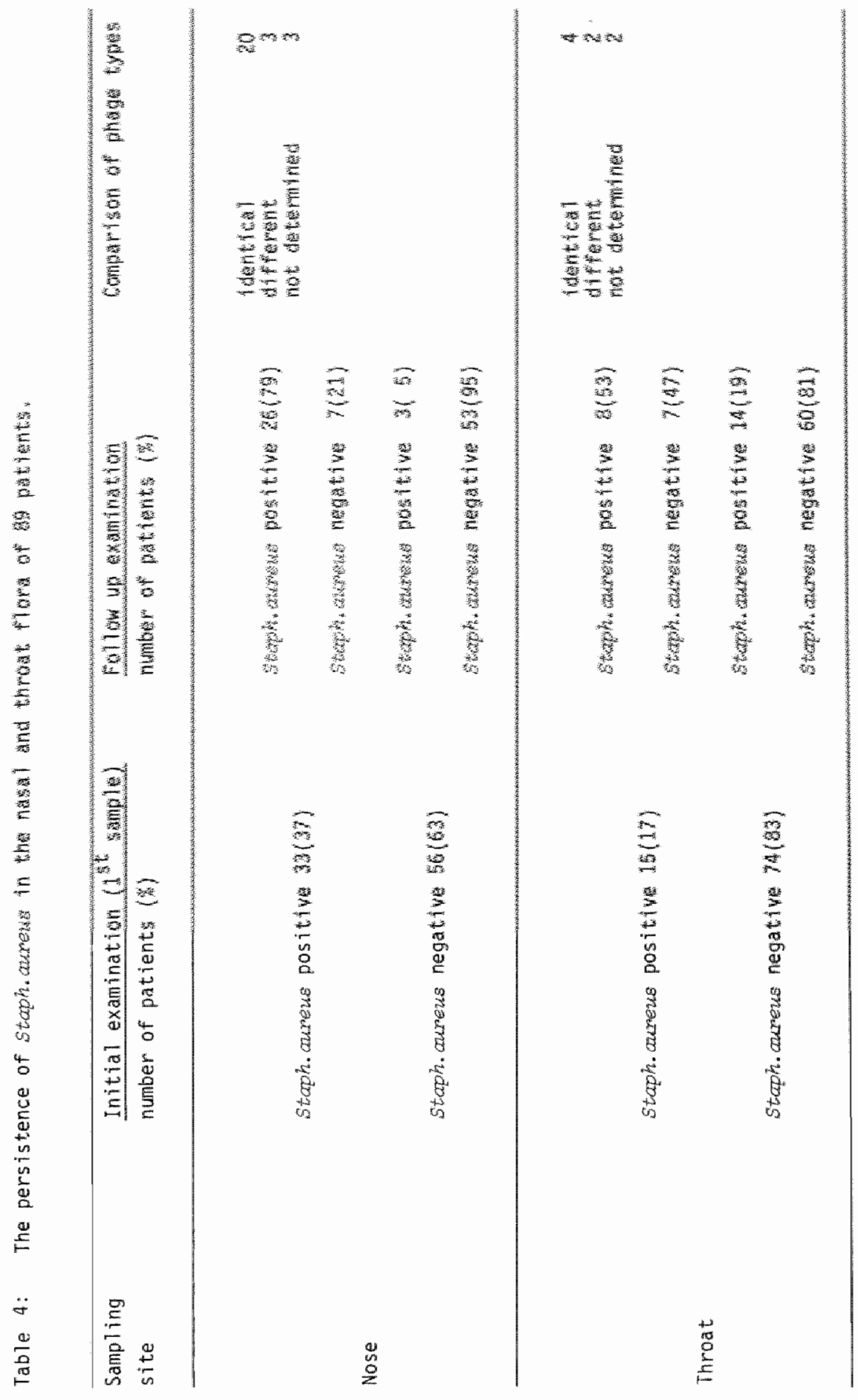


Table 5: The presence of Stoph caureus in the nasal and throat flora of 183 employees as shown by the first samble of the initial examination.

Number of employees

Category

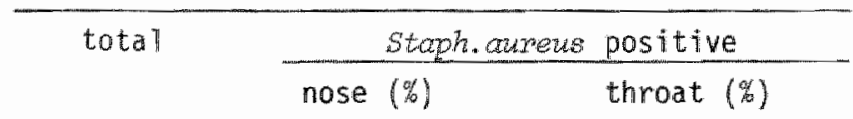

Ward nurses.

31

$15(48)$

$3(10)$

Laboratory technicians

48

$14(29)$

$13(27)$

Operating room personne]

47

$18(38)$

9 (19)

Physiotherapists

15

$3(20)$

2 (13)

student nurses

42

$14(33)$

9 (21)

Tota1

183

$64(35)$

$36(20)$ 


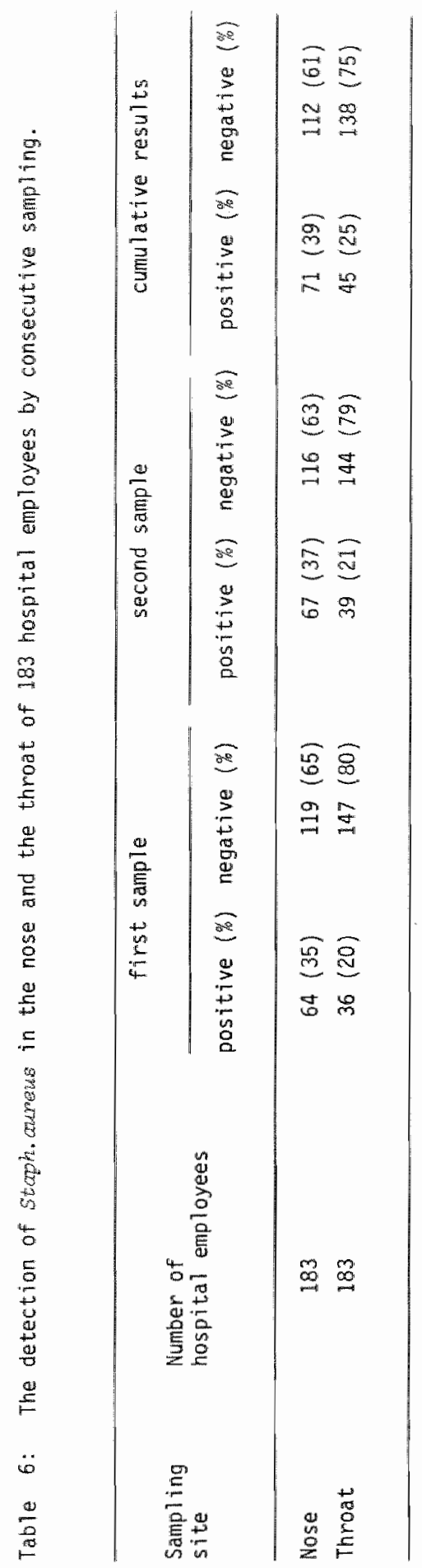




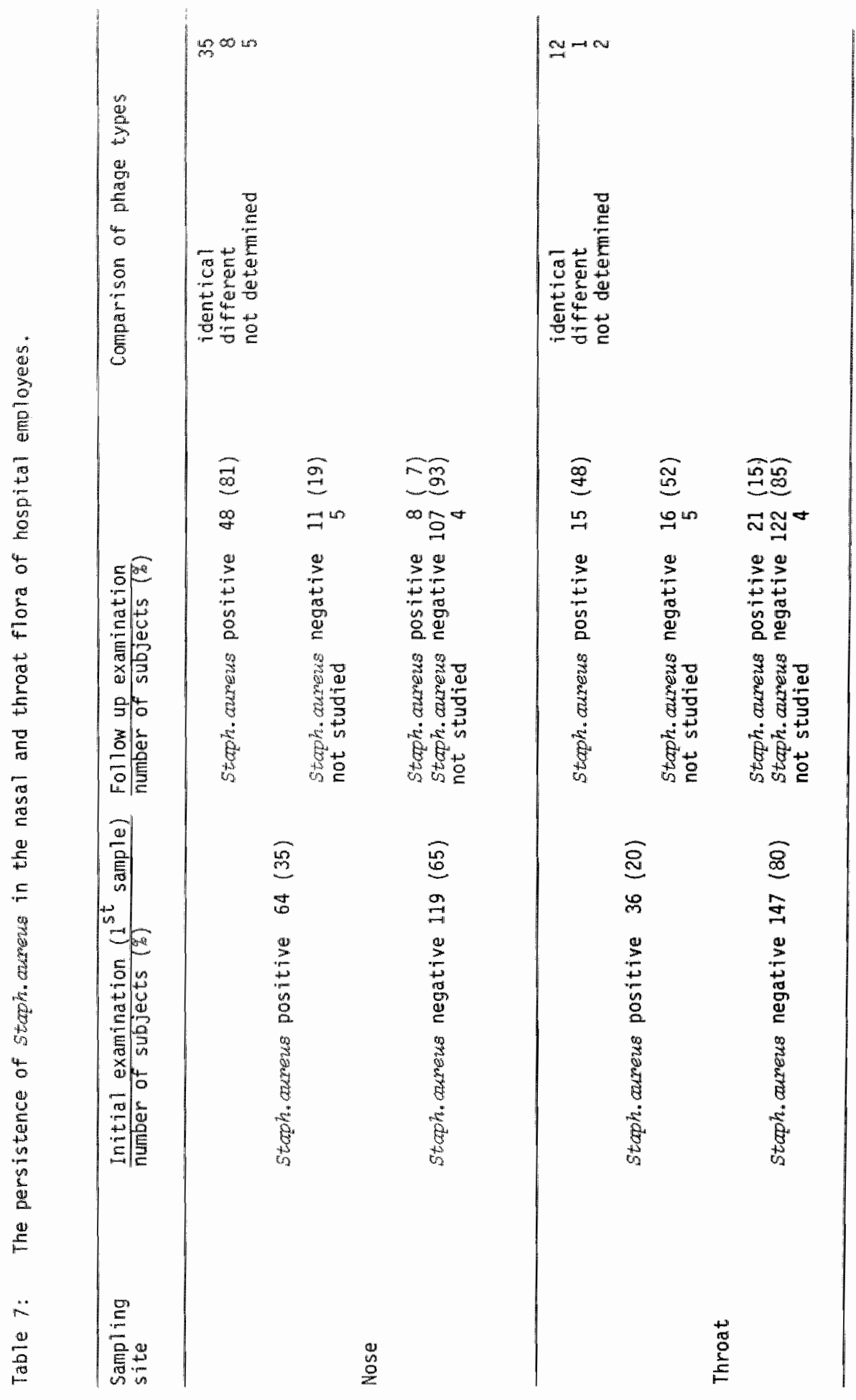




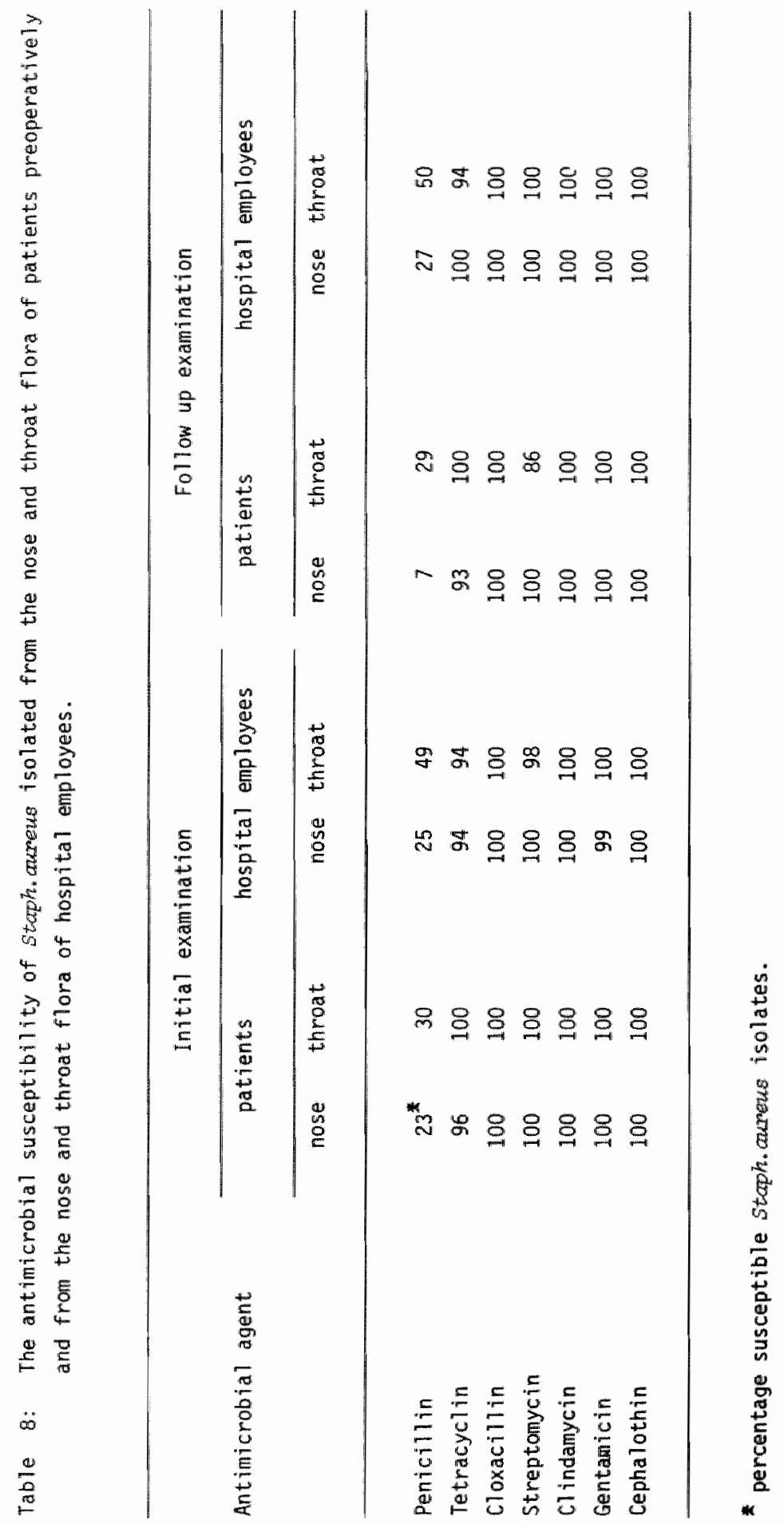


Stoph. curreus positive in both examinations, had another phage type in the follow up examination than the strain isolated at the initial examination.

The throat flora was also re-sampled seven days after the initial examination. Only $15(48 \%)$ out of the 31 employees who were re-sampled and who were initially staph.cureus positive remained stoph.oureus positive (table 7). At least one of the 15 subjects had another strain than at the inftial examination. At the initial examination, no stoph. aureus was cultured from the throat of 147 employees. One week later, $21(15 \%)$ of the 143 recultured employees had acquired this microorganism and at least 16 (52\%) of the recultured employees had lost this microorganism.

\subsection{SUSCEPTIBILITY OF STAPH. AUREUS TO ANTIMICROBIAL AGENTS}

In total, 225 gtoph. oureus strains were tested. Resistance to penicillin was found in more than half of the strains isolated from patients and hospital employees (table 8). All strains were susceptible to cephalathin, the antimicrobial agent used as prophylaxis for patients undergoing openheart surgery.

\section{DISCUSSION}

The rate of Stoph. aureus carriage is dependent on the accuracy of the method used to investigate this carriage. We used the most frequently employed sampling method, namely the swabbing method. After sampling the site being examined, the swab was smeared over the surface of a solid medium.

In order to determine the accuracy of this swabbing technique using direct plating the nose and throat were sampled twice by taking two consecutive samples. The results of these two consecutive samples revealed that $s t a p h$. auxeus was not present in the first sample from $8.3 \%$ of the patients harbouring this microorganism in their nose and from $16.6 \%$ of the patients with staph. aureus in their throat flora if only one sample was taken. Similar results of the first and second consecutive sampling of the nose and throat flora in hospital employees were found. of the Stoph.aureus positive employees, $9.9 \%$ of them would have been considered as negative if only one sample was taken from the nose. In case of the throat flora, $20 \%$ of the Staph aureus positive employees would not have been detected if this sampling site was swabbed only once. 
Differences in the number of staph andews positive subjects can be due to differences in the sampling technique (10). A nigher number of 3 taphi. aurews positive subjects was found if moistened cotton-tipped swabs instead of dry cotton-tipped swabs were used (11). However, dry cotton-tipped swabs are most frequently used and results of comparative studies are not available. Is has been suggested that the site of sampling in the nose influences the number of Staph. auxeus positive samples. Samples obtained from the higher reaches of the nose yielded staph aureus more often than samples from the vestibule of the nose (12). However, according to others, swabbing beyond the vestibule might produce artificially low carrier rates $(13,14)$. The culture method for the swabs used to detect staph. aureus carriage affected the yield of positive samples. Polakoff et al. (15) incubated the swabs in the broth after direct plating. They found that only $88 \%$ of nasal carriers were detected by direct plating. The frequency of sampling seems to affect the number of positive samples as we71. This was studied by Solberg (16) who determined the numbers of staph.aureus calony forming units in five consecutive samples obtained from persistent staph. aumeus carriers. The first two samples yielded higher numbers of organisms than the last two. Therefore, more than two consecutive samples to detect the presence of stoph anureus will have only a 1 imited increasing effect on the detection rate of Staph. aureus positive subjects (16).

Comparing the results of the two consecutive samples abtained from the nose and the throat of the subjects of our study, it appeared that the increase of staph. cureus positive throat samples was markedly higher than the increase of staph. curcus positive nose samples. This suggests that the faiture of a singlle swabbing to isolate stoph.adreus from the pharyngeal area is greater than in case of nasal swabbing, probably due to the lower number of Staph.comeus in the throat flora compared to the number in the nasal flora (16).

The transiency of the presence of Stoph. careus in the throat flora was significantly greater than in the nasal flora $(p<0,03)$. Among patients, $21.2 \%$ of the initilally positive patients lost staph awoeu from their nares and $5.4 \%$ of the initially negative patients acquired this microorganism at this site. Within two days, however, Staph.aumeus was lost from the throat flora in $46.7 \%$ of the initially positive patients and was acquired in $18.9 \%$ of the initially negative patients. Hospital employees were re-investigated one week after the initial examination staph.couneus was no longer present in the nose flora of $18.6 \%$ and in the throat flora of $51.3 \%$ of the initially 
Staph.cureus positive employees. Acquistion of $s$ taph. careus in the nasal and throat flora of hospital employees occurred in $6.9 \%$ and in $14.6 \%$, respectively. These findings in conjunction with those obtained from the patients showed that the presence of Staph. caweus in the nasal and throat flora was rather transient within well defined but short periods. Surprisingly, this transiency was not caused by an increased acquisition but was due to a significant loss of stopk caureus from the flora in both patients and employees within the rather short intervals ( $p \leqslant 0,02)$.

It is reported that among patients during hospitalization the number of staph.awareus positive patients is increased $(1,10,13)$ and that among hospital employees the rate of carriers is higher than that of a general population and even exceeds that of patients $(10,13)$. However, Burke and. Corrigan (17) and Williams et az. (13) indicated that among patients the increase is variable and that a fall in the number of staph. aureus positive patients can be noticed inside the hospital. Because a decrease in the nasal carriage was observed in patients nursed in artificially ventilated wards and in patients nursed in separate rooms, this fall was apparently not directly related to enviromental differences (13). A factor accounting for a decrease of Stophameus positive patients during hospitalization has been reported to be the use of antibiotics (18). However, in other studies the use of antibiotics was shown to result in acquisition of Staph. aureus $(19)$.

Our patients, not treated with antimicrobial agents, had a significant loss of staph. aureus within two days after admission. It might be that this loss was due to the presence of antibiotics in the environment which can eliminate antibiotic sensitive strains (20), creating a void for the resistant strains (21). However, the staph. aureus strains isolated from nasal and throat flora were mostly sensitive for the antibiotics tested, except penic $111 \mathrm{in}$. Therefore, the loss of $s$ toph.amreus must be attributed to as yet unknown factors. It is tempting to speculate that such factors are related to the ability of the epithelial cells in the nose and the throat to adhere this microorganism.

A higher postoperative infection rate has been reported to occur in patients with staph. aureus positive nose cultures compared to patients without staph aureus in their nasal flora (1-6). In other studies no relation was found between the presence of staph. aureus in the nasal flora of patients on admission and the occurrence of postoperative infections $(22,23)$. We found, in our patients, no relation between the 
results obtained from the preoperative surveillance cultures and the occurrence of postoperative infections due to Stoph. autreus, regardless of preoperative topical antimicrobial treatment. However, the number of patients in our study was small. The four patients with a postoperative infection due to staph aureus were negative on admission for this microorganism. These four patients might have been so-called light Stoph.aureus carriers (24) who are unlikely to be detected by a single nasal sampling. Because we found that five percent of the patients without Staph.oureus in their nasal flora on admission acquired this microorganism within two days, another explanation might be that these four patients became positive. A third possibility which was not investigated, is that contamination of the patient occurred in the operating room during surgery from warious sources. 


\section{REFERENCES}

1. Williams, R.E.0., Jevons, M.P., Shooter, R.A., Hunter, C.J.W., Girling, J.A., Griffiths, J.D. and Taylor, G.W. Nasal staphylococci and sepsis in hospital patients. Br.Med.J.2: 658,1959.

2. Henderson, R.J. and Williams, R.E.O. Nasal disinfection in prevention of post-operative staphylococcal infection of wounds. Br.Med.J. 2: 330,1961.

3. Calia, F.M., Wolinsky, E., Mortimer, E.A. Jr., Abrams, J.S. and Ramnelkamp, C.H. Jr. Importance of the carrier state as a source of Staphyzocoocus coureus in wound sepsis. J.Hyg. (Camb). 67: 49,1969.

4. Siebbeles, H.W.R. Onderzoek naar de bronnen van de postoperatieve wondinfecties met staphytococous aureus. Amsterdam, 1968. Dissertation.

5. Bengtson, S., Hambraeus, H. and Laure11, G. Wound infection after surgery in a modern operating suite. J.Hyg. (Camb.) 83: 41,1979.

6. Dyas, A.C., Eden, P.u., Eastwood, D., Bentley S., Burdon, D.W., Alexander-Williams, J. and Keighly, M.R.B. Sources of staphylococcal wound sepsis in surgical patients. J.Hosp.Inf. 3: 345, 1982.

7. Weinstein. H.J. The relation between the nasal-staphylocaccal-carrier state and the incidence of postoperative complications. New. Surg.J.Med. 260: 1303,1959 .

8. Lindbom, G. Studies of the epidemiology of staphylococcal infections. 2. Staphylococcal infections in a thoracic surgery unit. Acta Chir. Scand. 128: 421,1964 .

9. Lindbom, G., Laure11, G. and Grenvik, A. Studies on the epidemiology of staphylococcal infections. 3. Influence of factors inherent in the patient and his operation. Acta Pathol. Microbiol.Scand.(B). 69: 219,1967. 
10. Hilliams, R.E.O. Healthy carriage of Stophy Locoocus aureus: its prewalence and importance. Bact.Rev. 27: 56,1963.

11. Borst, J. Staphylococcen in een kraamkliniek. Een epidemiologisch onderzoek met behulp van bacteriofaagtypering maar de besmetting van moeders, zuigelingen en personeel. Amsterdam, 1960. Dissertation.

12. Stratford, B., Rubbo, S.D., Christie, R. and Dixson,S. Treatment of the nasal carrier of Staphy Lococous cureus with framycetin and other antibacterials. Lancet 2: 1225,1960 .

13. Williams, R.E.0., Blowers, R., Garrod, L.P. and Shooter, R.A. In: Hospital infection. Causes and prevention. 2nd ed. London: Lloyd-Luke Ltd., 1966;22.

14. Moss, B., Squire, J.R., Topley, E. and Johnston, C.M. Nose and skin carriage of Stophylococous aureus in patients receiving penicillin. Lancet 1: 320,1948 .

15. Polakoff, S., Richards, L.D.G., Parker, M.T. and Lidwell, 0.M. Nasal and skin carriage of Staphyzococous coureus by patients undergoing surgical operations. J.Hyg. (Camb.) 65: 559, 1967.

16. Solberg, C.0. A study of carriers of Stophyzoeocous aureus with special regard to quantitative bacterial estimations. Acta Med. Scand. 178: suppt. 436,1965 .

17. Burke, J.F. and Corrigan, E.A. Staphylococcall epidemiology on a surgical ward. Fluctuations in ward staphylococcal contents, its effect on hospitalized patients and the extent of endemic hospital strains. New.Eng.J.Med. 264: 321,1961.

18. Lidwell, O.M., Polakoff, S., Jewons, M.P., Parker, M.T., Shooter, R.A., French, V.I. and Dunkerley, D.R. Staphylococcal infection in thoracic surgery: experience in a subdivided ward. J.Hyg. (Camb.) 64: 321,1966. 
19. Knight, V. and Holzer, A.R. Studies on staphylococci from hospital patients. I. Predominance of strains of group III phage patterns which are resistant to multiple antibiatics. J.Clin. Invest. 33: 1190,1954.

20. Gould, J.C. Environmental penicillin and penicillin resistant staphy Locoocus cureus. Lancet 1: 489, 1958.

21. Williams, R.E.0., Blowers, R., Garrod, L.P. and Shooter, R.A. In: Hospital infection. Causes and prevention. 2nd ed. London: Lloyd-Luke Ltd., 1966; 272.

22. Public Health Laboratory Service. Incidence of surgical wound infection in England and WaTes. Lancet 2: 659,1960.

23. Bassett, H.F.M. , Ferguson, W.G. Hoffman, E., Walton, M., Blowers, R. and Conn, C.A. Source of staphylococcal infection in surgical wound sepsis. J.Hyg. (Camb.).61: 83,1963.

24. Shooter, R.A., Thorn, B.T., Dunkerly, D.R., Taylor, G.W., Parker, M.T. John, M. and Richards, J.D.G. Postoperative segregation of patients in a surgical ward. Brit.Med.J.2: 1567, 1963. 


\section{CHAPTER V}

BACTERIOLOGICAL SURVEILLANCE OF THE EXTRA CORPOREAL CIRCIJIT; RELATION BETWEEN THE MICROORGANISMS ISOLATED AND THOSE INVOLVED

IN THE OCCURRENCE OF POSTOPERATIVE BACTERAEMIA, SEPTICAEMIA, AND/OR EARLY-ONSET BACTERIAL. ENDOCARDITIS 


\section{INTRODUCTION}

The incidence and seriousness of postoperative infections in open-heart surgery is higher than in closed-heart surgery (1-4). This suggests that the use of the extra corporeal circuit (ECCt) may be one of the risk factors for acquiring infections after open-heart surgery. The finding of a high level of contamination of the oxygenator at the end of the extra corporeal circulation (ECCu) supports this suggestion $(5,6)$. However, not always could a contribution of the ECCt to the probability of postoperative infections be demonstrated $(7,8)$.

Contamination of the ECCt can occur at different moments. Before the open-heart operation, the system can be contaminated during assembly of the circuit and during the priming of the circuit with a priming solution and donor blood. During the operation the operative field is usually contaminated with microorganisms from several sources (9). Blood from the operative field is aspirated by suckers into the cardiotomy reservoir and returned to the oxygenator of the ECC. . From there, contamination of the intravascular compartment of the patient can occur. The relevance of such contamination in relation to the occurrence of postoperative bacteraemia, septicaemia and infective endocarditis is not clear (10).

As part of our infection surveillance programme, we studied the contamination rate of the ECCt regardless of the source. Samples from the circuit were taken prior to and at the end of the ECCu. In this chapter, the results of the bacteriological monitoring in rellation to the occurrence of postoperative bacteraemia, septicaemia and/or early-onset bacterial endocarditis (BE) are reported.

In addition, the contamination of the ECCt was studied in more detall in a number of operations in order to determine more accurately the contamination rate and the relation to postoperatively occurring bacteraemia, septicaemia and/or $B E$.

\section{MATERIALS AND METHODS}

\subsection{THE EXTRA CORPOREAL CIRCUIT AND ITS ASSEMBLY.}

The ECCt connected to the heart lung machine (Sarns 5000 Console, Sarns, Ann Arbor, Michigan, U.S.A.) used during this study was composed of the 
following elements:

1. the oxygenator (Galen optiflo 1, Cobe, Denver, U.S.A.)

2. the cardiotomy reservoir (Cobe, Denver, U.S.A.)

3. the arterial line filter (Swank HF 6000, Cobe, Derver, U.S.A.)

4. the arterial cannula (Sherwood, Petit Rechain, Belgium) and the tubes of the arterial line (Tygon S $50 \mathrm{HL}$, Norton Company, Akron, U.S.A.)

5. the venous cannula (Porges Couvelair, Porges, Paris, France) and the tubes of the venous lines (Tygon $550 \mathrm{HL}$ )

6. the left ventricle camnula(Porges Couvelair) and the tubes of the cardiotomy suction set

7. the suckers and the tubes of the cardiotomy suction set (Tygon $550 \mathrm{HL}$ ) A diagram of the ECCt is shown in figure 1 .

The ECCt was assembled the day before operation in a separate room in which the sterilized elements were stored. This room was situated in the sterile zone of the operating suite. After washing and cleaning the hands using povidone-iodine soap (Betadine $\mathbb{R}$, Dagra, Diemen, The Netherlands), the perfusionist assembled the circuit. During the assembly, he wore a face-mask and a cap. No other persons were allowed to enter this room. All elements of the circuit were disposable and pre-sterilized and used within the indicated periad of sterility guarantee. The tubes connecting the different elements (arterial and venous lines, cardiatomy suction set) were sterillized in the hospital using ethylene-oxide and also stared in the assembly room. On the day of operation, the heart lung machine was rolled into the operating room. After the operation, the heart lung machine was dismantled and cleaned in a room outside the sterile zone of the operating suite.

Just prior to operation, the extra corpareal circuit was filled with the priming solution. This solution contained haemaccel (Behring Institute AG, Marburg, Fed.Rep.Germany) $2500 \mathrm{ml}$; human albumen (20\% $\mathrm{w} / \mathrm{v}$; Institut Merieux. Lyon, France) $125 \mathrm{ml}$; mannitol (10 $\mathrm{w} / \mathrm{w} / \mathrm{v}) 100 \mathrm{ml}$; heparin $125 \mathrm{mg}$ in $2.5 \mathrm{ml}$; potassium chloride and sodium bicarbonate in concentrations depending on the results of blood analysis. Depending on the preoperative hematocrit of the patient donor blood was added to this priming solution.

\subsection{BACTERIOLOGICAL SAMPLING AND METHODS}

The ECCt was studied during the last 121 operations because the assembly of the Ecct during the first ten months of the survey period was not performed according the procedures as described above. 
A sample was collected from the priming solution in the ECCt before starting the ECCu. The 121 samples were drawn from the venous inlet of the oxygenator (figure 1, no 8). During the open-heart operation a blood sample was drawn from the sampling port of the oxygenator (figure 1 , no. 9) five minutes before teminating the ECCu. During 45 ECCu's randomly selected from the 121 open-heart operations studied, blood samples were taken at regular intervals of 30 minutes from the venous inlet of the oxygenator (figure 1, no. B) and from the outflow side of the cardiotomy reservoir (figure 1, no. 10) concurrently. A11 samples were taken by the perfusionist. Ten $m$ l of the priming solution or of blaad from the ECCt was inoculated inta two blood culture media after the caps of the bottles had been disinfected with jodine $(1 \% \mathrm{w} / \mathrm{v})$ in ethanol $(70 \% \mathrm{v} / \mathrm{v})$. Bacteriological studies done at the Laboratory for Medical Microbiology, Eindhoven, The Netherlands, were identical to those described for processing blood cultures in chapter III.

The methods for isolation, identification, susceptibility testing, phage and biotyping (11) and the criteria for comparison of the strains were as described previously (Chapter III).

\subsection{DEFINITIONS.}

Postoperative bacteraemia was defined as the isolation of identical microorganisms from two or more bload cultures obtained on separate occasions $(12)$.

Postoperative septicaemia was diagnosed when the patient had chills and a positive blood culture, or chills in conjuction with hypotension (systolic blood pressure $\leqslant 90 \mathrm{~mm} \mathrm{Hg}$ ) without a positive blood culture.

The diagnosis of $B E$ was based on the persistence of unexplained fever, the finding of persisting leucocytosis, the occurrence of a new regurgitant cardiac mumur and the isolation of identical microorganisms from at least two blood cultures. 


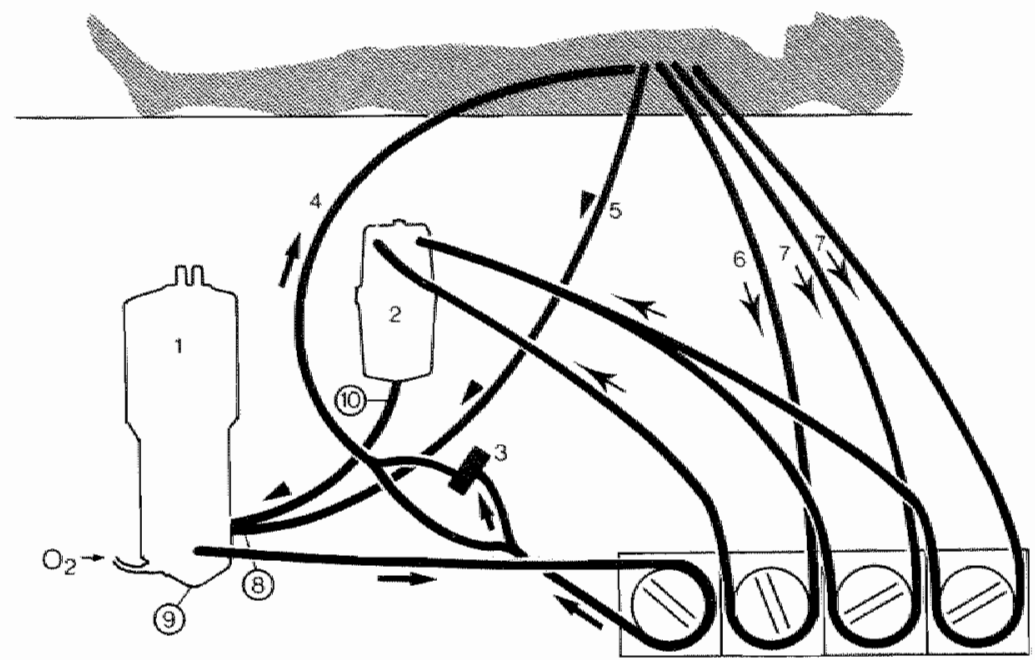

Figure 1: The extra corporeal circuit.

Legend:

1 = oxygenator

2 = cardiotomy reservoir

$3=$ arterial filter

4 = arterial line

5 = venous line

6 = left verticle drain

$7=$ cardiotomy suction lines

$8,9,10=$ sampling sites for bacteriological cultures 


\section{RESULTS}

3.1. SINGLE CULTURES FROM THE PRIMING SOLUTION BEFORE STARTING AND FROM THE BLOOD OF THE OXYGENATOR. AT THE END OF 121 EXTRA CORPOREAL CIRCULATIONS

Microarganisms were isolated from $31(25.6 \%)$ of the 121 samples from the priming solution before the ECCu was initiated (table 1). At the end of the ECCu, bacteria were isolated from six (5.0\%) out of 121 samples from the oxygenator blood (table 1). In three open-heart operations samples from both the priming solution and the oxygenator blood were positive but in oniy one case the same microorganism (Bacizizs species) was cultured from the priming solution and from the blood of the oxygenator. Mainly stoph. epidermidis and Bacithus species were cultured from the priming solution (table 2). Staph epidermidis were tested for susceptibillty to cephalothin. Two strains were resistant. Two out of three sarcina species isolated were also resistant to this antibiotic. An unidentified Gram-negative rod and an unidentified fungus species were cultured once. Mainly Bacizlus species were cultured from the oxygenator samples (table 2). Escherichia coti, Citrobacter freundit and Aspergillus species were isolated once. E.coli was sensitive for cephalothin and the other two microorganisms were resistant to this antibiotic.

of the samples of the priming solution from which bacteria were isolated, six yielded growth of more than one microorganism. One of these six samples contained four different nicrorganisms whereas five samples yielded growth of two different isolates. In one of the six positive blood cultures from the oxygenator two different microorganisms (E.coti and viridans streptococci) were isolated. Another sample of the blood from the oxygenator yielded growth of four different microorganisms (E.coli, viridans streptococci, Baciltus species and Aspergizzus spectes).

No relation was found between the inicroorganisms cultured from the samples taken before and at the end of the ECCu and the occurrence of postoperative bacteraemia, septicaemia and $B E$ (table 3).

The bacteriological findings from the oxygenator samples initiated postoperative antimicrobial treatment in two patients. One patient with a positive blood culture due to $\mathrm{s}$.coli and viridans streptococci was postoperatively treated with penicill in and gentamicin. He later developed BE due to Stoph.epidexmidis. A second patient with a blood culture from the oxygenator yielding citr. freundit resistant to cephalothin was 


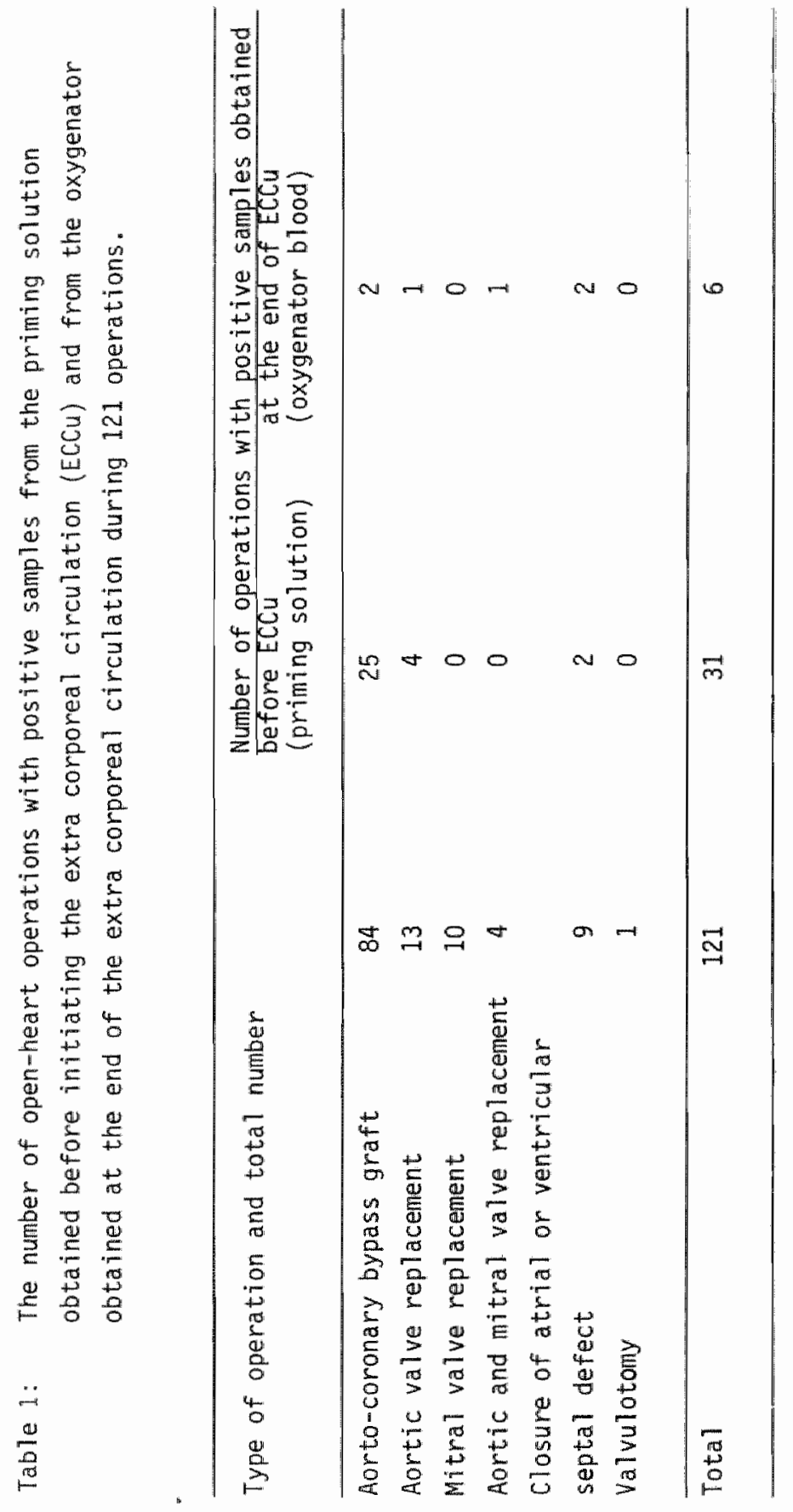


Table 2: The microorganisms isolated from the priming solution before initiating the extra corporeal circulation (ECCu) and from the blood from the oxygenator at the end of the extra corporeal circulation.

\begin{tabular}{ccc}
\hline Microorganism & Sampling time \\
\cline { 2 - 3 } & before Eccu & at the end of Eccu \\
(priming solution) & (oxygenator blood) \\
\hline
\end{tabular}

Staphy tocoacus epidermidis

$\begin{array}{ll}15(2)^{*} & 0 \\ 3 & 0 \\ 12 & 5 \\ 3(2) & 0 \\ 0 & 1 \\ 2 & 0 \\ 2 & 1 \\ 1 & 0 \\ 0 & 1(1) \\ 0 & 1 \\ 0 & 1(1) \\ 1 & 0\end{array}$

Staphy tococons aureus

Bactilus species

Saroina species

Streptococcus viridans group

Gram-positive rods (unidentified)

Diphteroids

Gram-negative rods (unidentified)

critrobatex freundi

Escheniahia coti

Aspergiztus species

Other fungi (unidentified)

* In parenthesis: number of strains resistant to cephalothin. 


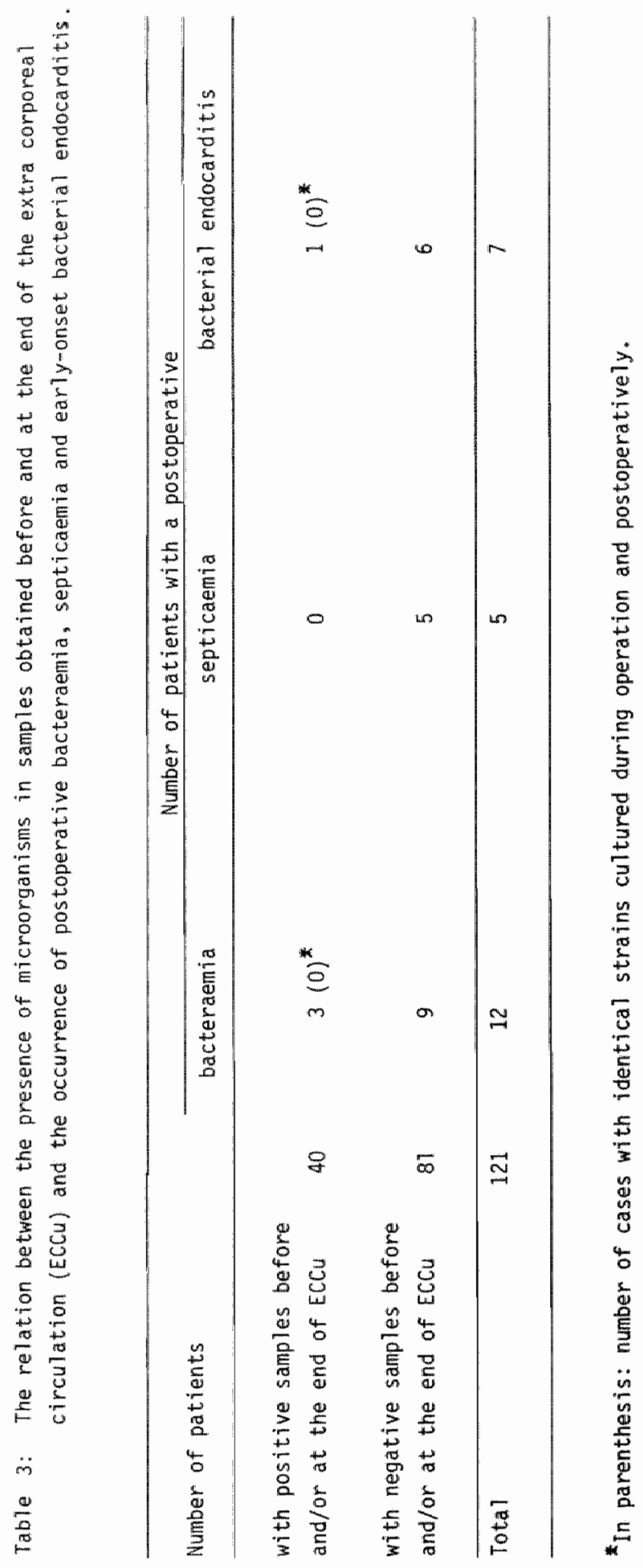


postoperatively treated with cefuromim. The postoperative course was uneventful.

\subsection{MULTIPLE CULTURES FROM THE CARDIOTOMY RESERVOIR AND FROM THE VENOUS INLET OF THE OXYGENATOR DURING THE EXTRA CORPOREAL CIRCULATION OF 45 OPEN-HEART OPERATIONS}

In 45 out of the 121 open-heart operations, samples were taken at regular intervals from the cardiotomy reservoir and the venous inlet of the oxygenator. In total, 158 samples from the cardiotomy reservoir and 158 samples from the oxygenator were taken. Cultures taken during 23 (51\%) out of the 45 ECCu's showed the presence of microorganisms (table 4). Eighteen samples taken from the cardiotomy reservoir used during 16 ECCu's were positive. The results of the samples concurrently taken from the venous inlet of the oxygenator showed that nine samples were positive during eight openheart operations. During only one ECCU were samples from both the cardiotomy reservoir and from the oxygenator positive. Two different microorganisms were isolated. Single sampling performed before and at the end of these 45 ECCu's showed that the priming solution was positive in nine cases, whereas only one sample taken at the end of the ECCu was positive (table 4).

A variety of microorganisms was isolated from the cardiotomy reservoir and from the blood of the oxygenator (table 5). From the venous inlet of the oxygenator only Gram-positive bacteria and one fungus species were cultured whereas from the cardiatomy reservoir Gram-positive microorganisms, an Aspergizlus species, Gram-negative rods (Acinetobacter, Serratia) and Neisseria species were cultured. A11 isolates were sensitive for cephalothin except the isolated serratia species. The patient operated with use of an ECCt contaminated by this Serratia species was treated postoperatively with gentamicin.

The occurrence of postoperative bacteraemia, septicaemia and/or BE could not be related to the occurrence of contamination of the ECCt as demonstrated by single sampling before and at the end of the ECCu or by multiple sampling during Eccu (table 6). Cumulation of the results of the single and multiple sampling programmes resulted in 30 (67\%) pasitive ECCt's. A relation between the use of positive ECCt's and the occurrence of postoperative bacteraemia, septicaemia and/or BE could also not be demonstrated. 


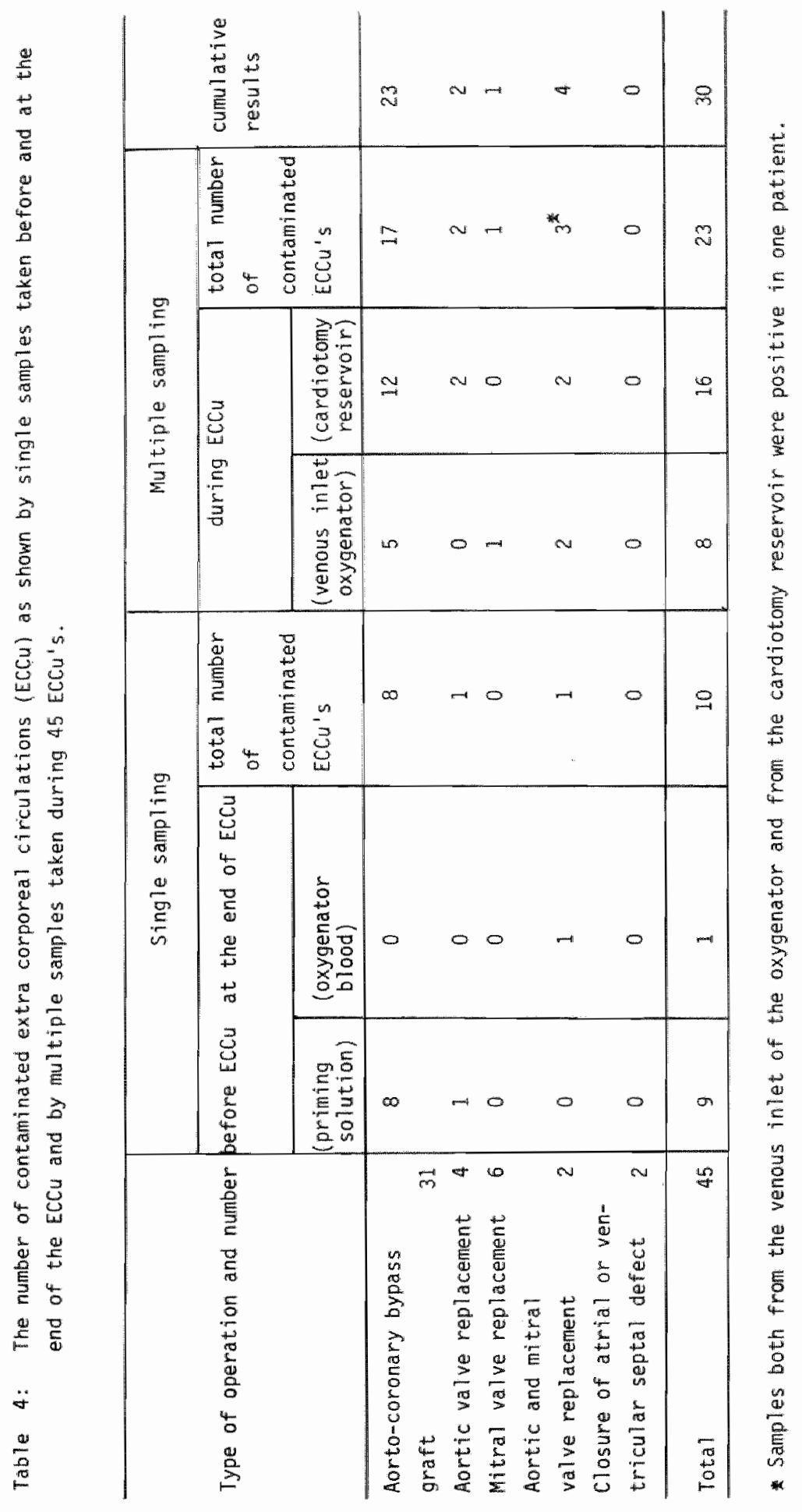




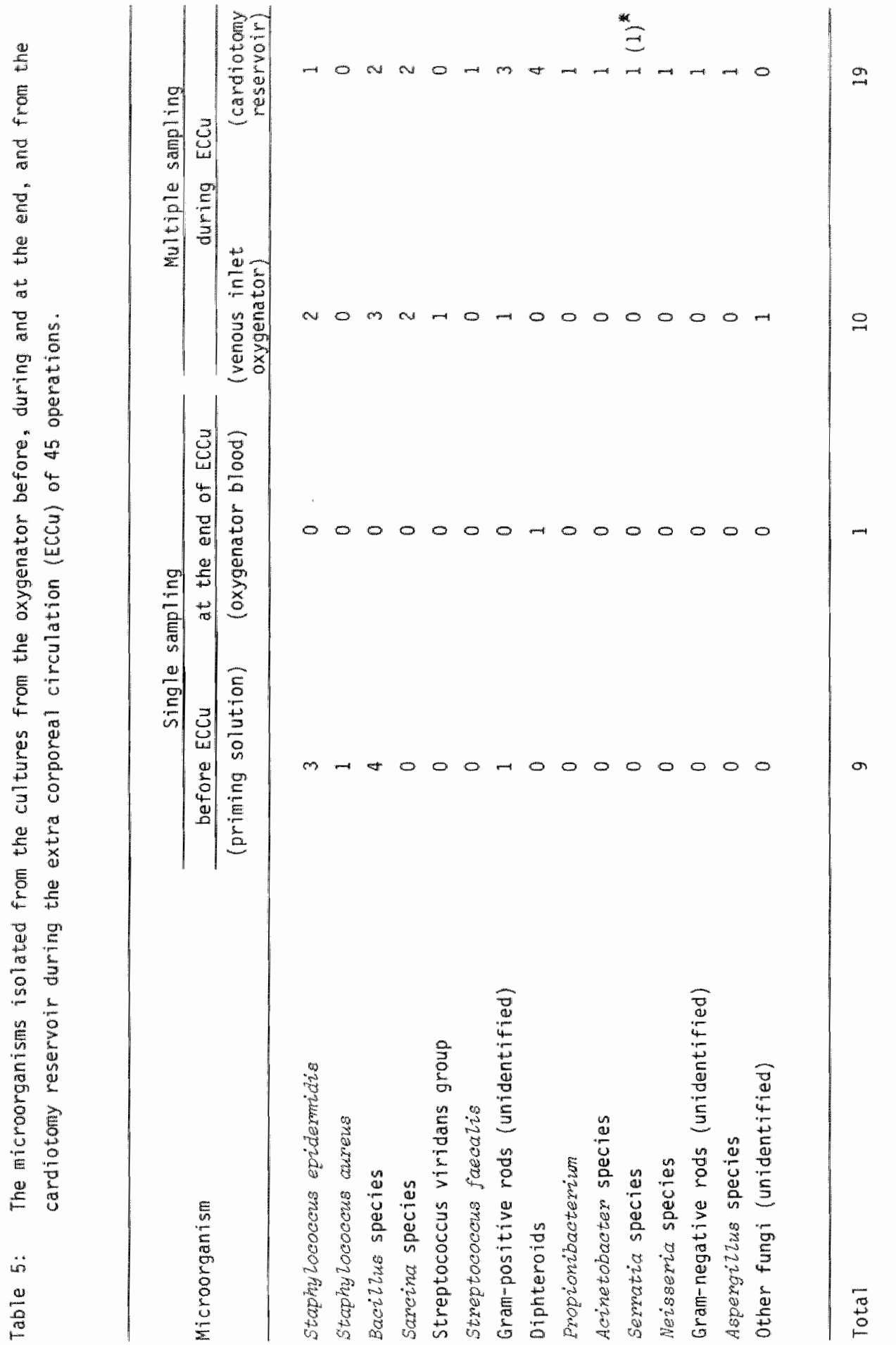




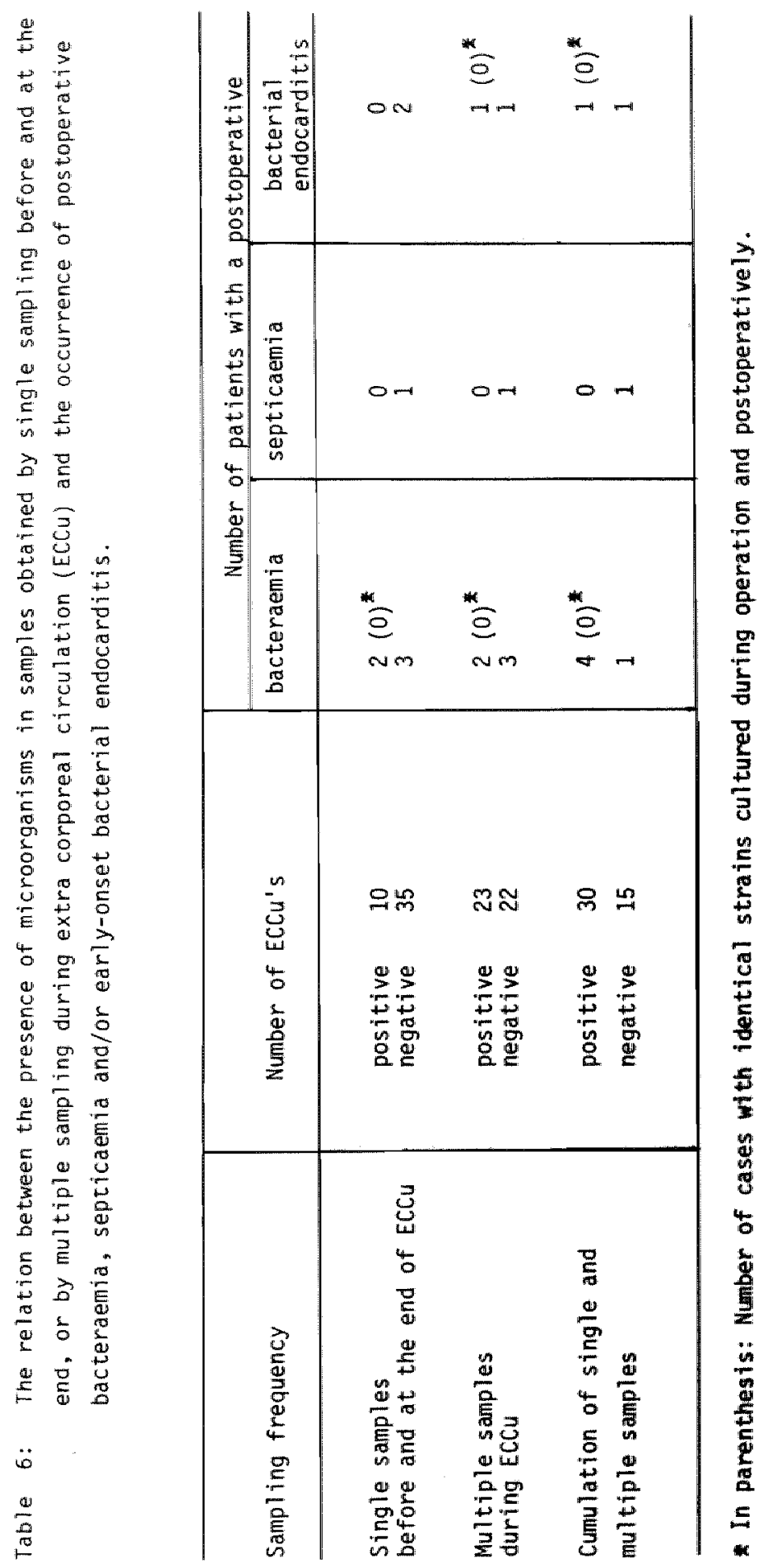




\section{DISCUSSION}

An attempt to detemine the clinical relevance of isolating microorganisms from the prining fluid and blood samples during ECCu was made by evaluating the results of these cultures and those of the pastoperative blood cultures. Based upon the results obtained from single samples taken before and at the end of the ECCu we found no relation between the use of a contaminated ECCt and the occurrence of postoperative bacteraemia, septicamia and/or $B E$. In the cases of postoperative $B E$ more infections occurred in patients being operated with culture negative Ecct's than in patients with culture positive ECCt's. This suggests that intraoperative contamination of the ECCt is less sigmificant than intravascular contamination fron other sources. However, three patients were treated postoperatively with appropriate antibiotics to treat a possible intravascular infection as soon as the culture results became available. The absence of a correlation between positive cultures obtained during operation and postoperative clinical findings might be due to an inefficient sampling procedure. Blakemore et $a z$. (5), applying an extensive sampling programme claimed that clinical postoperative infections were caused by microorganisms of the same species as. those recovered from the blood in the ECCt. We sampled the ECCt intensively in 45 operations and we again found no relation between the use of culture positive ECCt's and the occurrence of postoperative bacteraemia, septicaemia and/or BE. In other studies the clinical significance of positive ECCt cultures has not been established either $(10,13)$.

The results obtained from single cultures taken from the ECct before and at the end of the ECCu, showed a rather high contamination rate. Microorganisms were recovered from $31(25.6 \%)$ out of 121 samples from the priming solution before the ECCu was initiated. Taking into account the relatively small volume cultured $(10 \mathrm{ml})$ from about $3000 \mathrm{ml}$ of priming solution the number of microorganisms in this solution was rather high. This indicates that the heart lung machine was contaminated during the assembly procedure or during filling of the ECct with the priming solution. In this study the various sources from which the isolated microarganisms could have derived were not studied. However, published data $(5,14)$ do suggest that a lower number of positive priming solutiom samples can be obtained.

The number of positive cultures obtained from the oxygenator at the end of the ECCu was relatively low. This low number of positive samples may be due to an inadequate sample volume or to an effect of the prophylactically 
administered antibiotics or to the antibacterial properties of human blood.

other investigators, also studying small volumes $(5-10 \mathrm{~m} l)$ collected from the ECCt, found contamination rates similar to ours $(4,10,13,14)$. Blakemore et a2. (5) increased the sample volume from $5 \mathrm{ml}$ to $25 \mathrm{ml}$ and the frequency of sampling by obtaining additional samples on several occasions, and found that the contamination rate of the ECCt increased to $75 \%$. We increased the sampling frequency during 45 ECCu's and isolated microorganisms fron $30(67 \%)$ Ecct's. If in these 45 ECCu's only single sampling was performed, microorganisms would have been isolated from ten (22\%) instead of 30 ECCt"s.

Apart from the increase of the sampling frequency, the volume cultured was relatively smal1. Culturing the disposable oxygenator after filling postoperatively with broth. Dankert (6) reported that the inside of the axygenators was contaminated in about $80 \%$.

Another factor to consider is the effect of prophylactically administered antibiatics on the culture results. The isolation rate of microorganisms from samples taken during ECCu was increased from $8.3 \%$ to $17.7 \%$ when the prophylactically administered antibiotics were specifically neutralized in the blood culture medium used (10). This is furtner supported by the results obtained by Kluge et a2. (9). In this study cephalothin (1 gm intramuscularly every six hours) and kanamycin (0.5 gm intramuscularly every 12 hours) were used as prophylaxis for open-heart surgery patients. Serum levels were assayed and were found to be inadequate to kill most bacteria, but the results of the cultures from the oxygenator, using media without an inactivator, revealed that only two out of the 66 samples contained bacteria. one of our media contained sufficient penicillinase to counteract 10,000 units of pentcillin. Although the serum level of cephalothin, the antiblotic prophylactically administered in our patients, was not assayed it is very likely that cephalothin levels were rather high during ECCu (15). Therefore, our finding that all isolates from the oxygenator, except one, were sensitive to cephalothin indicates that the amount of penicillinase in the media used was high enough to counteract cephalothin present in the blood samples, although it is known that penicillinase in lower concentrations is not the most appropriate inactivator of cephalothin $(16,17)$.

The presence of milcroomganisms in the priming solution before ECCu did not predict the presence of microorganisms in oxygenator blood at the end of Eccu. This reduction might be caused by antibacterial activity of the blood. However, further studies are necessary to determine the effect of blood alone or in cambination with antibiotics on the viability of microorganisms 
contaminating the heart lung machine. From animal studies it is known that only serum resistant E.coti (18) and Paeudomonas aeruginosa (19) were able to induce endocarditis.

Another relevant question is how during ECCU contamination of the heart. lung machine occurred. Partiy the microorganisms might have been derived from the preoperatively contaminated heart lung machine itself but also from the patient's own flora and from the enviroment of the operating room, especially from the air. The Ecct can be directly and indirectly contaminated from the air. Direct contamination can accur due to suction of air into the cardiotomy reservoir. The ECCt can be indirectly contaminated from the air by microorganisms first sedimented into the wound and then sucked with blood into the cardiotomy reservoir.

Cultures taken from the cardiotomy reservoir during 45 operations revealed that $16(36 \%)$ reservoirs were contaminated. The reservoirs were contaminated twice as often as the blood fram the venous iniet of the axygenator suggesting a possible role of the reservoir as a site of entry of microorganisms into the circuit. Another feature indicating the difference between these two sample sites was the finding of a much wider variety of bacterial species in samples obtaimed from the reservoir. Contamination of the cardiotomy reservoir was found to be reduced when airborne contamination of the wound area was prevented $(6,14)$.

Fram the results we conclude that microorganisms which often cause postoperative infective endocarditis were isolated from the ECCt. Furthermore, the yield of positive cultures from the Ecct can be increased if appropriate culturing procedures and intensive sampling are performed. Microorganisms cultured from samples taken from the ECCt were not involved in postoperative bacteraemia, septicaemia and/ar BE. In agreement with others (10) our results also showed that there was no relation between the use of a contaminated. ECC.t and the occurence of postoperative bacteraemia, septicaemia and/or BE. This indicates that other sources than the Ecct might be more important in inducing postoperative bacteraemia, septicaemia and/or BE. 


\section{REFERENCES}

1. Kittle, C.F., and Reed, W.A. Antibiatics and extrá corporeal circulation. J.Thorac.Surg. $41: 34,1961$.

2. Stein, P.D., Harken, D.E., and Dexter L. The nature and prevention of prosthetic valwe endocarditis. Am. Heart J. 71: $393,1966$.

3. Goodman, J.S., Schaffner, W., Collins, H.A., Battersby, E.J., and Koenig, M.G. Infection after cardiovascular surgery. Clinical study including examination of antimicrobial prophylaxis. New. Eng1. J.Med. 278: 117,1968.

4. Carey, J.S. and Hughes, R.K. Control of infection after thoracic and cardiovascular surgery. Ann. Surg. 172: 916,1970.

5. Blakemore, W.S., McGarrity, G.J., Thurer, R.J., Wallace, H.W., MacVaugh, H. III and Corie 11, L.L. Infection by air-borne bacteria with cardiopulmonary bypass. Surgery $70: 830,1971$.

6. Dankert, J. The use of a mobile cross-flow unit in open-heart surgery: a bacteriological evaluation. Ant.v.Leeuwenh. 44: 247, 1978.

7. Baffes, T.G., Blazek, W.V., Fridman, J.L., Agustsson, M.H., and van Elk, J. Postoperative infections in 1,136 consecutive cardiac operations. Surgery 68: 791,1970 .

8. Frater, R.W.M., and Santos, G.H. Sources of Infection in open-heart surgery. M.Y. State J.Med. 74: $2386,1974$.

9. Kluge, R.M., Calia, F.M., McLaughlin, J.S. and Hornick, R.B. Sources of contamination in open-heart surgery. JAMA 230: 1415, 1974.

10. Freeman, R. and Hjersing, N. Bacterial culture of perfusion blood after open-heart surgery. Thorax 35: 754,1980 . 
11. Stra1, M.J. Stobberingh, E.E., Hawerkorn, M.J. and van Boven, C.P.A. Application of phage-typing and biotyping to the eptdemiology of coagulase-negative Staphylococci in cardiowascular surgery. In: J.Jeljaszewicz, ed. Staphylococci and Staphylococcal infections. Proceedings of IV international symposium on Staphylococci and Staphylococcal infections. Zb1.Bakt. Suppl.10 Stuttgart-New York: Gustav Fischer Verlag, 1981;189.

12. Burke, J.P. Infections of cardiac and vascular prosthesis. In: J.V. Bennett and P.S. Brachman, eds. Hospital Infections. Boston: Little, Brown and Company, 1979; 307.

13. Yeh, T.J., Anabtawi, I.N., Cornett, V.E., White A., Stern, W.H., and Ellison, R.G. Bacterial endocarditis following open-heart surgery. Ann. Thorac. Surg. 3: 29,1967.

14. Lathrop, G.D., Brockett, R.M., and Blouse, L.E. Epidemiologic surveillance for Staphy Zococeus epidermidis infections, related to cardiopulmonary bypass. Zb1. Bakt. Hyg., I.Abt. Orig. A 241: 108,1978 .

15. Miller K.W., Chan, K.K.H., Mc Coy, H.G., Fisher, r.P., Lindsay and Zaske, D.E. Cephalothin kinetics: Before, during and after cardiopulmonary bypass surgery. Clin. Pharmacol. Ther. 26: 54, 1979.

16. Newsom, S.W.A. and Walsingham, N.M. The use of B-lactamases in the clinical laboratory. J.Med.Microbiol. 6: 59,1973.

17. Russel1, A.D., Ahonkhai, I., and Rogers, D.T. Microbiological applications of the inactivation of antibiotics and other antimicrobial agents. J.Apl1. Bact. 46: 207, 1979.

18. Durack, D.T., Beeson, P.B. Protective role of complement in experimental Weaherichic coli endocarditis. Infect. Immun. 16(1): 213, 1977.

19. Archer, G., Fekety, F.R., Jr.: Experimental endocarditis due to Paeudomonas ceruginosa. I. Description of a model. J.Infect.Dis. 134: 1,1976 . 
CHAPTER VI

THE SIGNIFICANCE OF ISOLATION OF STAPHYLOCOCCUS EPIDERMIDIS FROM BLOOD CULTURES OBTAINED FROM PATIENTS AFTER OPEN-HEART SURGERY 


\section{INTRODUCTION}

Coagulase-negative staphylacocci, which are called in this study Staphy Lococus epidexmidis are often regarded as contaminants of blood cultures (1) due to their presence in the microbial flora of the human skin and mucous membranes, their presence in the air and at various other sites. If staph.epidemidis is isolated from a blood culture from a patient after open-heart surgery, especially after a valve replacement operation, this microorganism merits attention because of its possible role in inducing septicaemia or intravascular infections. One of these intravascular infections is so-called prosthetic valve endocarditis (PVE) occurring after prosthetic valve replacement surgery. PVE can be classified according to the time period in which the disease occurs. Early-onset PVE is defined as an endocarditis occurring within 60 days of valve implantation $(2,3)$. Late-onset PVE occurs more than 60 days after valve implantation $(2,3)$. The mortality of PVE is high. In early-onset PVE the mortality (71.4\%) is significantly higher than in late-onset PVE: $45.6 \%$ (4). This indicates that PVE is a serious infectious complication of open-heart surgery. Unfortunately, an early diagnosis of PVE is difficult because of the lack of specific symptoms (5-7). Therefore, PVE often creates a clinically important, difficult, diagnostic dilemma (8). Staph-epidermidis is the most frequently isolated species causing eariy-onset PVE $(3,4)$. In late-onset PVE Staph.epidermidis is also frequently isolated $(3,4)$. If staph.epidermidis is isolated from blood cultures obtained from patients after open-heart surgery with prosthesis implantation the differentiation of contaminated blood cultures from valid positive cultures due to a bacteraemia or an intravascular infection is necessary (9). The isolation of an identical microbial species from at least two blood cultures has been regarded as a major clue to the diagnosis of PVE $(2,3,6,10,11)$.

In the first seven months after starting cardiac surgery in February 1978,18 patients out of 37 from whom postoperative blood cultures were collected, had positive blood cultures mainly due to stoph.epidermidis. However, symptoms of septicaemia or early-onset PVE were absent.

Usually multiple blood samples are drawn within a certain period of time to differentiate contamination from bacteraemia. In the literature data about the frequency of contamination of blood cultures drawn from different sites concurrently are lacking (12).

In this study we evaluated the results of paired blood samples 
concomitantly taken from patients after open-heart surgery.

\section{MATERIALS AND METHODS}

The total number of patients from whom paired blood samples were drawn was 273. The number of patients initially involved was enlaraed because the number of patients involved in the other parts of the study was too small to achieve the probability of significant results. Therefore, we extended our study beyond the indicated period (Chapter II) and included an additional number of 137 open-heart surgery patients.

Blood cultures were taken postoperatively if the body temperature, measured rectally, was raised above $38.5^{\circ} \mathrm{C}$, or if signs and symptoms consistent with septicaemia and/or an intravascular infection existed. Furthermore, during the course of an antimicrobial therapy of PVE additional bloodcultures were taken frequently. Paired blood culture samples were obtained by concurrent venipuncture from the antecubital vein of the left and the right arm of the patient after cleansing of the skin with iodime $(1 \% \mathrm{w} / \mathrm{v})$ in ethanol $(70 \% \mathrm{v} / \mathrm{v})$. The screw caps of the culture bottles were also cleansed with iodine in ethanol. After collection of the blood $(10 \mathrm{ml})$, the needle of the syringe was replaced by a new disposable sterilized needle, and the blood was injected into two bottles containing culture media (see chapter III). The culturing procedures, the susceptibility testing and the biotyping of the staph. epidermidis isolates have been previously described in detail (see Chapter III).

\section{RESULTS}

A total of 537 paired blood samples was obtained from 273 patients after open-heart surgery (table 1). Samples were taken from 229 patients, in whom no prosthetic material was inserted. Most of them (216) had an aorto-coromary bypass graft operation. The remaining 44 patients had a Björk-Shiley prosthetic valve implanted. Palred blood samples were taken from the patients with a prosthetic valwe allmost three times as often as from the other patients.

staph.epidermidis was mot cultured from $442(82.3 \%)$ of the 537 paired samples (table 2). From $88(16.4 \%$ ) out of the 537 blood culture pairs, staph.epidermidis was isolated from one of the two cultures whereas in seven 


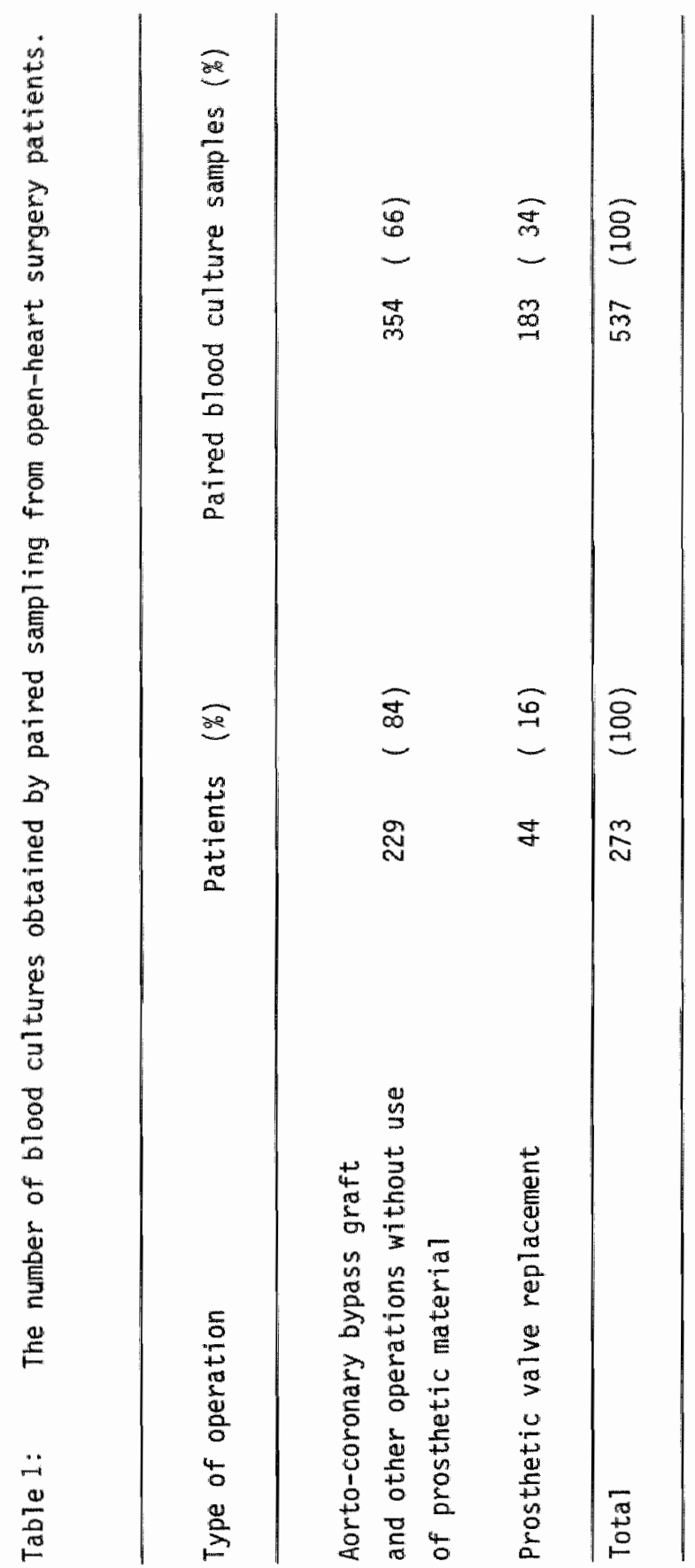


Table 2: The isolation of stophylococens epidermidis from paired blood cultures obtained from patients after open-heart surgery.

Strophy tocoocus epidemidis isolated from

both samples

one sample

none of the two samples
Number of paired

samples (\%)

$537 \quad(100.0)$ 
(1.3\%) blood sample pairs both cultures yielded growth of Staph.epidermidis. These seven positive pairs were obtained from seven different patients. Three of them had undergone a prosthetic valve implantation and one was treated afterwards for an early-onset PVE due to Stoph.epidermidis. In this latter patient both stoph.epidermidis isolates from the paired samples had an identical biotype and susceptibility pattern. The other six patients showed during and after their febrile period no signs and symptoms of an intravascular infection and therefore antimicrobial treatment was not given. The strains of staph.epidermidis isolated from the paired samples of these six patients showed a different biotype and susceptibility pattern, and were therefore considered to be non-identical.

\section{DISCUSSION}

Stoph.epidemidis is generaliy regarded as a non-pathogenic microorganism present in the microflora of the skin and mucous membranes of men. In hospitals this microorganism can be easily isolated from the air and from several environmental sites. Therefore, the isolation of staph.epidermidis from clinical specimens including blood samples, has been regarded for many years as contamination (13). However, in the last decade Staph.epidermidis has been recognized as the cause of serious infections, occurring after insertion of surgical prostheses in neurosurgery $(14,15)$, orthopaedic surgery $(14,16)$, vascular surgery (17) and open-heart surgery $(2-7,14,18-25)$ patients. In addition, this microorganism has caused postoperative infections after general (26-29) and closed-heart surgery $(18,20)$, urinary tract infections $(27,30)$ and indwelling vascular catheter-associated infections $(31,32)$. In neutropenic patients serious infections due to stoph.epiderstidis have also been reported (33).

Since early-onset PVE is often caused by stoph.epidermidis (3.4), Stcoph.epidermidis isolated from blood cultures obtained from patients after open-heart surgery cannot be dismissed as representing a contaminant. Multiple isolations of stoph.epidermidis from repeated blood cultures are used to distinguish between contaminated and valid positive blood cultures due to bacteraemia or septicaemia (9). The time intervals between the multiple blood collections are seldom indicated $(9,12,33,34)$.

We collected paired blood samples concurrently from patients after open-heart surgery to distinguish between contamination and bacteraemia 
due to Staph.epidemidis. Eighty-eight out of 537 paired blood samples yielded growth of Staph.epidermidis in one of the two samples, suggesting contamination. Both samples were positive for Staph.epidermidis in seven out of the 537 paired blood samples, suggesting bacteraemia. In order to assess if a number of these seven positive paired samples contained staph epidermidrs due to contamination we evaluated the results as follows. If single sampling had been performed instead of paired sampling, 51 (seven plus half of the 88 samples) out of 537 single samples would have been positive for Stoph.epidermidis, corresponding to a probability of $9.5 \%$ positive samples. Assuming that these 51 samples were positive due to contamination, the probability of obtaining two stoph.epidexmidis positive cultures after a repeated sampling would have been $(9.5 \%)^{2}$ of 537 . This would have meant that on five occasions two samples could be expected to contain staph.epidemmidis as a result of contamination. We isolated Staph.epidexmidis in seven cases from both samples. Applying the chi square test for testing statistical significance no statistical difference was found between the five sample pairs to be expected to contain Stoph. epidermidis and the seven pairs from which this microorganism was actually isolated $(p=0.8)$. This indicates that a significant contribution of bacteraemia to the probability of blood cultures positive for Staph.epidermidis was not found. This conclusion is further supported by results obtained from biotyping and susceptibility testing, because non-identical staph.epidermidis strains were isolated from each of six of the seven positive paired samples. In one of the seven cases biotyping and susceptibility testing revealed the presence of identical staph. epidexmidïs strains in both samples. In contrast to the other six patients, this patient had additional signs and symptoms of an early-onset PVE and was treated with appropriate antimicrobial agents. This finding fllustrates that biotyping and susceptibility testing of multiple isolated Stoph.epidemidis can add essential information for differentiating contamination and bacteraemia if paired blood samples are taken. If multiple blood samples are drawn repeatedly these test procedures can also be helpful to distinguish between contamination and bacteraemia. 
1. MacGregor, R.R. and Beaty, H.N. Evaluation of positive blood cultures. Guidelines for early differentiation of contaminated from valid positive cultures. Arch. Int. Med. 130: 84,1972.

2. Dismukes, W.E. and Karchmer, A.W. The diagnosis of infected prosthetic heart valves: bacteremia versus endocarditis. In: R.u.Duma, ed. Infections of prosthetic heart valves and vascular grafts. Baltimore: University Park Press, 1977; 61.

3. Watanakunakorn, C. Prosthetic valve infective endocarditis. Prog. Cardiovasc. Dis. 22: 181,1979 .

4. Mayer, K.H. and Schoenbaum, S.C. Evaluation and management of prosthetic valve endocarditis. Prog. Cardiovasc. Dis. 25: 43,1982.

5. Amoury, R.A., Bauman, F.0.Jr. and Ma1m, J.R. Endocarditis associated with intracardiac prostheses. J.Thorac.Cardiovasc.Surg., 51:36,1966.

6. Dismukes, W.E., Karchmer, A.W., Buckley, M.J., Austen, W.G. and Swartz, M.N. Prosthetic valve endocarditis. Analys is of 38 cases. Circulation 48 : 365,1973 .

7. Wilson, W.R., Jaumin, P.M., Danielson, G.K., Giuliani, E.R. Washington II, J.A. and Geraci, J.E. Prosthetic valve endocarditis. Ann. Intern. Med. 82: 751,1975 .

8. Weinstein, L. Infected prosthetic valves: A diagnostic and therapeutic dilemma. New Eng.J.Med. 286: 1108, 1972.

9. Burke, J.P. Infections of cardiac and vascular prosthesis. In: J.V.Bennett and P.S. Brachman, eds. Hospital Infections. Boston: Little, Brown and Company, 1979; 307.

10. Block, P.C., DeSanctis, R.W., Weinberg, A.N. and Austen, W.G. Prosthetic valve endocarditis. J.Thorac. Cardiovasc. Surg. 60: 540,1970. 
11. Rossiter, S.J., Stinson, E.B., Oyer, P.E., Craig Miller, D., Schapira, J.N. Martin, R.P. and Sumway, N.E. Prosthetic valve endocarditis. Comparison of heterograft tissue valves and mechanical valves. J.Thorac.Cardiovasc. Surg. 76: 795,1978 .

12. Lewis, J.F. and Alexander, J.J. Blood cultures in bacteremia. South. Med.J. 75: 147,1982 .

13. Kloos, W.E. and Smith, P.B. Staphylococci. In: E.H.Lennette, A.Balows, W.J.Hansler, Jr., and J.P. Truaut, eds. Manual of clinical microbiology. $3^{\mathrm{d}}$ ed. Washington, D.C.: American Society for Microbiology, 1980; 83 .

14. Garvey, G. Endovascular and prosthetic implant infections. In: M.H.Grieco, ed. Infections in the abnormal host. New York: Yorke Medical Books, 1980; 693.

15. Verhoef, J., Peterson, P.K., Williams, D.N., Laverdiere, M. and L.D.Sabath. Atrio-ventricular shunt infections and endocarditis due to Staphylococous epidermidis. Zb1. Bakt. Hyg. I. Abt. orig. A 241: 95,1978.

15. Clarke, A.M. Prophylactic antibiotics for total hip arthroplasty- the significance of Stcopkyzococcus epidermidis. J. Antimicrob. Chemother. 5: $493,1979$.

17. Liekweg, W.G., Levinson, S.A. and Greenfield, L.J. Infections of vascular grafts: incidence, anatomic location, etiologic agents, morbidity and mortality. In: R.J.Duma, ed. Infections of prosthetic heart valves and vascular grafts. Baltimore: University Park Press, 1977; 239.

18. Quinn, E.L. and Cox, F. Jr. Staphy Lococecus albus (epidermidis) endocarditis: report of 16 cases seen between 1953 and 1962. Antimicrob. Agents Chenother. 3: 635, 1964.

19. Geraci, J.E., Hanson, K.C., and Giuliani, E.R. Endocarditis caused by coagulase-negative staphylococci. Mayo $\mathrm{Clin}$. Proc. 43: 420,1968. 
20. Keys, T.F. and Hewitt, W.L. Endocarditis due to Micrococci and Stophylococcus epidermidis. Arch. Intern. Med. 132: 216,1973.

21. Slaughter, L., Morris, J.E. and Starr, A. Prosthetic valvular endocarditis. A 12-year review. Circulation 47: 1319,1973.

22. Speller, D.C.E. and Mitche11, R.G. Coagulase-negative staphylococci causing endocarditis after cardiac surgery. J.C1in.Path. 26: 517,1973.

23. Hornick, R.B. Source of contamination in open-heart surgery. In: R.J. Duma, ed. Infections of prosthetic heart valves and vascular grafts. Baltimore: University Park Press, 1977; 81.

24. Marples, R.R., Hone, R., Notley, C.M., Richardson, J.F. and CreesMorris, J.A. Investigation of coagulase-negative staphylococci from infections in surgical patients. Zb1. Bakt. Hyg. I. Abt. Orig. A. 241: 140,1978 .

25. Lathrop, G.D., Brockett, R.M. and Blouse, L.E. Epidemiologic surveillance for Stcophylococous epidermüdis infections related to cardiopu7monary bypass. Zb1. Bakt. Hyg. I. Abt. Orig. A. 241:108,1978.

26. Wilson, T.S. and Stuart, R.D. StaphyZococous albus in wound infection and in septicemia. Can. Med. Assoc. J. 93: 8,1965.

27. Blouse, L.E., Lathrop, G.D., Kolone1, L.N. and Brockett, R.M. Epidemiologic features and phage types associated with nosocomial infections caused by Staphy lococous epidermidis. Zb1. Bakt. Hyg. I.Abt. Orig. A., 241: 119, 1978.

28. Jara, F.M., Toledo-Pereyra, L., Lewis, J.W. and Magilligan, D.d. The infected pacemaker pocket. J.Thorac. Cardiovasc. Surg. 78: 298,1979.

29. Sewe11, C.M., Clarridge, J.E., Young, E.J. and Guthrie, R.K. Clinical significance of coagulase-negative staphylococci.J.Clin.Micrabiol. 16: 236,1982 . 
30. Marsik, F.J. and Brake, S. Species identification and susceptibility to 17 antibiotics of coagulase- negative staphylococci isolated from clinical specimens. J.clin. Microbio1. 15: 640,1982.

31. Forse, R.A., Dixon, C., Bernard, K., Martinez, L., Mclean, A.P.H. and Meakins, J.L. Stophy Zocacous epidermidis: an important pathogen. Surgery 86: $507: 1978$.

32. Sitges-Serra, A., Puig, P., Jaurietta, E., Garau, J., Alastrue, A. and Sitges-Creus, A. Catheter sepsis due to Staphyzococous epidermidis during parenteral nutrition. Surg. Gynecol. Obstet. 151: 481,1980.

33. Wade, J.C., Schimpff, S.C., Newman, K.A. and Wiernik, P.H. Stcophytococous epidemidis: an increasing cause of infection in patients with granulocytopenia. Ann. Int. Med. 97: 503,1982.

34. Barry, A.L. Clinical specimens for microbiologic examination. In: P.D. Hoeprich, ed. Infectious Disease, $2^{\text {nd }}$ ed. Hagerstown: Harper and Row, 1977; 91 . 

CHAPTER VII

GENERAL DISCUSSION AND CONCLUSIONS 
The risk of acquiring an infection after open-heart surgery is determined by several factors: the presence of many potential sources of contamination, the implantation of prosthetic material and the impaiment of resistance of the patient.

Many occasions occur, efther during or after operation, on which the patient can be contaminated or infected by potential pathogenic microorganisms $(1-6)$. During operation the operative field is contaminated by microorganisms derived from the air in the operating room (2) and from the hands of the members of the surgical team since their gloves are quite often pierced during surgery (7). By continuous suction on the cardiotomy suckers comnected to the extra corporeal circuit, microorganisms from the operative field can be introduced into the intravascular compartment. Entry to the intravascular compartment can also occur from the inserted intravascular catheters(8-14), and from the pressure transducer systems (14-18).

Another risk factor is the implantation of foreign material which increases the susceptibility of the patient to infections by microarganisms normally considered of low virulence, e.g. coagulase-negative staphylococci, further indicated as staphyzococous epidermidis (19). The adherence of this particular microorganism onto prosthetic valve material is not well understood. The finding of Christensen et al. (20) suggesting that slime producing Staph.epidemidis are more often associated with intravascular catheter-associated infections than non-slime producing strains, might imply that this extra cellular product plays a role. Also the type of prosthetic material seems to be of importance since Sugarman et al. $(21,22)$ showed that certain materials were more easily colonized by staph.epidemidis than other types of synthetic material or suture material.

The impairment of resistance of patients undergoing open-heart surgery, associated with the use of the extra corporeal circuit, is another risk factor which has to be considered. Although not a 11 studies on this aspect showed the same results (23), impaiment of the functions of leukocytes during and after extra corporeal circulation has been described (24-26). Furthermore, it has been shown that the clearance by the reticuloendothelial system is decreased during extra corporeal circulation (27).

After the open-heart operation the patient is cared for in an intensive care department. Sources and routes of contamination here are numerous. They are inherently associated with the intensive treatment $(14,28-30)$.

At the start of cardiac surgery in the Catharina Hospital at Eindhoven an infection surveillance programme was introduced and carried out. Procedures 
and measures for prevention of infection were described and made avallable to everyone concerned. The personnel of the department was regularly informed about the necessity of performing the recommended precautions and instructed to maintain a high quality of aseptic handing. In addition an explanation was given as to why cultures had to be taken. The incidence and type of infections were registered prospectively. A prospective registration and documentation of the infections occurring in the patients treated in the department of cardiac surgery from the very start and using strictly defined criteria, seemed important to monitor the quality of the precautions and to increase the awareness of the susceptibility to infection of patients undergoing open-heart surgery. The particular purpose of this study was, in addition to the registration, the assessment of the efficacy of some of the procedures and measures of the infection surveillance programme.

One of the procedures in the infection surveillance programme was, as mentioned in the literature $(4,5,31-34)$, the preoperative bacteriological sampling of various body sites of open-heart surgery patients on admission with the purpose to inventerize the patient"s microflora. Evaluation of the results of these cultures in relation to the microorganisms causing postoperative infections revealed that the microorganisms present in the admission flora of four patients with a postoperative early-onset bacterial endocarditis (BE), of 14 patients with a lower respiratory tract infection, of two patients with a bacteriuria and of four patients with a postoperative wound infection out of the total of 178 patients under study, were identical to those causing the postoperative infections. The majority of the postoperative infections was therefore caused by microorganisms not found in the preoperative cultures. This suggests that either the microorganisms were present but not detected by the method used, or the microorganisms were acquired during the patient"s stay in the hospital. A similar finding is that only $12 \%$ of the Stoph.epidemidis strains isolated from intravascular catheter tip cultures were identical to strains present in the admission flora.

The tips of these and other indwelling devices such as endotracheal tubes, wound drains and urinary catheters were as well cultured to test the assumption that a positive tip culture would predict the accurrence of a postoperative infection caused by the same microorganism. This study indicated that in general no relation was found between the microorganisms present on the tips of the intravascular catheters and of the wound and thoracic drains cultured after removal and the ricroorganisms causing postoperative 
infections. The results of the cultures of the tips of the endotracheal tubes showed in $69 \%$ of the lower respiratory tract infections a similar microorganism as those causing the infection in the same patient. In two cases of postoperative bacteriuria the microorganisms cultured from the urinary catheter tip were identical to those causing a subsequent bacteriuria.

Since the occurrence of postoperative infections due to staphytocodous cureus has been related to the preoperative presence of this microorganism in the endogenous nasal flara of patients, one of the elements in the infection surveillance programe was the screening of stoph. aureus carriage. sixty percent of the patients with Staph. careus positive nose samples were preoperatively treated with a nasal antimicrobial ointment. Assessment of the efficacy of this measure was, however, not possible due to the small number of postoperative infections caused by staph. aumeus. These occurred only in patients with stoph. auxeus negative samples. In the group of un-treated nasal carriers infections did mot occur. In most surveillance programmes the sampling method is not evaluated. The present study, however, indicated that the sampling technique to detect staph. aureus nose and throat carriers by single swabbing has a limited accuracy. The inconstancy of the presence of this microorganism in the nose and throat flora was demonstrated by the results of a repeated sampling of a rather large number of subjects.

Postoperative infections in open-heart surgery patients have also been suggested to originate from the use of a contaminated extra corporeal circuit $(2,35)$. To assess the possible role of a source of infection the extra corporeal circuit was sampled twice. The results were related to the accurrence of postoperative bacteraemia, septicaemia and/or BE. Even after an increase of the sampling frequency no relation could be shown between the microorganisms isolated from the samples and the accurrence of postoperative bacteraemia, septicaemia and/or BE.

Contamination of blood cultures occurs occasionally but at a definite rate depending on the precautions taken. The most frequent cause of contamination is Staph.epridermidis, due to its ubiquitous presence on the skin and in the hospital and laboratory environment. staph.epidemidis is also the most frequent cause of prosthetic valve endocarditis, a complication with a high - 46-71s - mortality rate (36). It is therefore important in case of isolation of staph.epidexmidis from a blood culture obtained from an openheart surgery patient to differentiate between contamination and infection. The approach taken in this study to evaluate the significance of staph. epidemidis positive blood cultures was to take paired blood samples. This 
Was based on the assumption that the isolation of stoph. evidematis from one of the two blood samples indicates contamination, whereas the isolation of this microorganism from both samples suggests bacteraenia or an intravascular infection. The results showed that $1.3 \%$ of the paired samples were both positive for staph. epadermidis. Statistically this percentage of positive paired blood cultures could be explaned as the result of contamination. This conclusion was confirmed by additional typing of the strains isolated from these positive paired samples. This indicated that the strains were different in six out of the seven cases. It is clear that to support the clinical diagnosis of an intravascular infection due to staph. epidemidis, multiple blood cultures should be taken to exclude false positive results. This can be done by taking twice paired blood samples within one hour. Furthermore, the isolated strains should be typed as detailed as possible to establish (mon-)identity. Rigorous aseptic precautions should be taken to reduce the chance of contamination.

The registration of postoperative infections in this study encompassed a period that should be considered as the initial phase in the history of the department of cardiac surgery of the Catharina Hospital at Eindhoven. In this period 182 open-heart aperations were performed. The overall infection rate based on the data of 178 open-heart operations was $35 \%$, whereas the incidence of prosthetic valve endocarditis was $18 \%$ in 34 valve replacement operations. Conparison of these data with those reported in the literature is difficult and of limited value. Most studies are retrospective and the data are derived from patient populations heterogeneous with regard to sex, age and type of surgery, as well as to the antimicrobial regimen used for prophylaxis. The variation in definitions to delineate postoperative infections - as 11 lustrated by one report (33) that does not mention the definitions - is another factor that seriously hampers comparison. Since also the avallable facilities and local conditions do affect the infection rate, it is necessary that a department of cardiac surgey introduces its own system for registration of postoperative infections.

Comparison of the observed infection rates with those reported in the literature, taking the above mentioned limitations into account, shows that both the overall rate of postoperative infections and the incidence of prosthetic valve endocarditis is higher than generally reported by others. It is not possible to indicate one obvious reason or cause for this difference. Lack of routine in keeping high standards of aseptic precautions, the relatively long period between admission and operation, the relatively 
Tong operation and perfusion times are factors which to all likelyhood contributed to the relative high incidence of infections observed during the period of study.

Two other studies $(37,38)$ reported the results of infection surveillance in open-heart surgery. Both reports describe a decrease of the infection rates as a result of amelioration of the infection surveillance programe. In the period of the present study an infection surveillance programe was introduced in the department of cardiac surgery. By emphasizing regularly the importance of aseptic handling and by providing relevant information, the awareness of the necessity to prevent infections increased, and the members of the team of the department of cardiac surgery became familiar with the survelllance programme. Strict and meticulous aseptic handling can only be achieved if the rationale for this is understood. This, however, is a process that needs time. Therefore, it could not be expected that a decrease in the infection rate as a result of surveillance would become apparent in the periad of study. However, the mesults abtained after the present study was concluded, indicate that the continued infection surveillance has significantly ameliorated the contamination and infection rates (39). This is illustrated by the results of bacteriological sampling of the extra corporeal circuit and by the incidence of postoperative early-onset bacterial endocarditis. In the period from January to June 1980,262 extra corporeal circuits were bacteriologically monitored. In $20(7.6 \%)$ and $5(1.9 \%)$ of the samples taken from the priming solution and the blood of the oxygenator respectively, bacteria were detected. This is a significant decrease in comparison with the 25.6\% ( $<<0.001)$ and $5 \%(p=0.015)$ positive samples of priming solution and of oxygenator blood respectively, as meported in this study (Chapter W). Similarly, the incidence of bacterial endocarditis recorded after 100 valve replacement operations performed between May 1981 and March 1983 was $1 \%$. Again a highly significant $(p<0.001)$ decrease in comparison with the in this study (Chapter III) reported incidence of $18 \%$ in 34 valve replacement operations. 
The results of the study permit the following conclusions or recommendations:

1. The management of a department of cardiac surgery should include an infection surveillance programme. It is essential that such a programine is introduced from the very start of the department. The present study demonstrated the usefullness of an early introduction of an infection surveillance programme. Altough it did not prevent a rather high incidence of postoperative infections in the period of this study, it brought to the attention the shortcoming of the infection survelllance. It is only after a certain time period that the the full benefit of an infection survelitance programme can be expected to become apparent, and as is shown by later results, indeed became apparent.

2. The criteria used for the diagnosis of postoperative infections in openheart surgery should be clear, unambiguous and preferably generally agreed upon. The data obtained by prospective registration of infections should be interpreted in relation to these criteria as well as to the phase of development of the department of cardiac surgery.

3. Routine preoperative bacteriological sampling of different sites on the skin and of mucous membranes of a cardiac surgery patient on the day of admission has a very limited value in predicting the microorganisms causing postoperative infections.

4. Culturing routinely the tips of indwelling devices removed postoperatively from open-heart surgery patients has no predictive value towards subsequently occurring infections and their causative microorganisms. An exception can be made for the tips of the endotracheal tubes.

5. Bacteriological sampling of the extra corporeal circuit before, during and at the end of extra corporeal circulation has no predictive value towards the occurrence of postoperative bacteraemia, septicaenia and/or early-onset bacterial endocarditis.

6. In this study preoperative carriage of staph careug in open-heart surgery patients could not be associated with a higher rate of postoperative infections among these carriers. 
7. The method of swabbing once the nose and throat of patients and hospital personnel to detect carriage of staph.caureus has a limited accuracy.

8. Carriage of staph. aujeus in the nose and throat of patients and hospital personnel is variable even within a short period. This variability of carriage is greater in throat than in nose carriers.

9. The isolation of Stoph. epidermidis from both cultures of a pair of blood samples concurrently obtained from patients after open-heart surgery does not necessarily indicate the occurrence of bacteraemia or an intravascular infection due to this microorganism.

To support the clinical suspicion or diagnosis of an intravascular infection caused by Stoph.epidemidis paired blaad samples should be taken twice within one hour. This procedure permits, in addition to characterization of the isolated strains using various typing techniques, an estimation of the chance of contamination. 


\section{REFERENCES}

1. Carey, J.A. and Hughes, R.K. Control of infection after thoracic and cardiovascular surgery. Ann. Surg. 172: $916,1970$.

2. Blakemore, W.S., Mc.Garrity, G.J., Thuner, R.J., Wallace, H.W., Mac Vaugh, H. III and Coriell, L.L. Infection by air-borne bacteria with cardiopulmonary bypass. Surgery 70: 830,1971.

3. Kluge, R.M., Calia, F.M., McLaughlin, J.S. and Hornick, R.B. Sources of contamination in open-heart surgery. JAMA 230: 1415,1974.

4. Rosendorf, L.L., Daicoff, G. and Baer, H. Sources of Gram-negative infection after open-heart surgery. J. Thorac. Cardiovasc.Surg. 67: $195,1974$.

5. Frater, R.W.M. and Santos, G.H. Sources of infection in open-heart surgery. N.Y. State J.Med. 74:2386, 1974.

6. Hornick, R.B. Source of contamination in open-heart surgery. In: R.J.Duma, ed. Infections of prosthetic heart-valves and vascular grafts. Balltimore: University Park Press 1977; 31.

7. Cruse, P.J.E. and Foord, R. The epidemiology of wound infection. A 10-year prospective study of 62,939 wounds. Surg. [ilin. North Am. 601:27,1980.

8. Goldmann, D.A., Maki, D.G., Rhame, F.S., Kaiser, A.B., Tenney, J.H. and Bennett, $\mathbb{H} . V$. Guidelines for infection control intrawenous therapy. Ann. Intern. Med. 79: 848,1973.

9. Maki, D.G., Goldmann, D.A. and Rhame, F.S. Infection controt in intravenous therapy. Ann. Intern. Med. 79: 867, 1973.

10. Konold, P., Ullman, U., Schrader, C.P. and Kieninger, G. Klinische und bakteriologische Beobachtungen bei intravenös eingeführten kathetern. atsch. Med. Wochenschr. 99: 1009, 1974. 
11. Maki, D.G., Weise, C.E. and Sarafin, H.W. A semiquantitative culture method for identifying intravenous, catheter-related infection. Mew. Eng1. J.Med. 296: 1305,1977.

12. Band, J.D. and Maki, D.G. Infections caused by arterial catheters used for hemodynamic monitoring. Am.J.Med. 67:735,1979.

13. Anonymous. Monitoring devices and septicaemia (Editorial). Br.Med.J. 2: 1747,1979 .

14. Meakins, J.L., Wicklund, B., Forse, R.A. and McLean, A.P.H. The surgical intensive care unit: current concepts in infection. Surg. CDin. North Am. $60: 117,1980$.

15. Weinstein, R.A., Emori, T.G., Anderson, R.L. and Stamm, W.E. Pressure transducers as a source of bacteremia after open-heart surgery. Report of an outbreak and guidelines for prevention. Chest 69: 338,1976.

16. Buxton, A.E., Anderson, R.L., Klimek, J. and Quintiliani, R. Failure of disposable domes to prevent septicaemia acquired from contaminated pressure transducers. Chest 74: 508, 1978.

17. Dreyden, G.E. and Brickler, J. Stopcock contamination. Anesth. Analg. 58: 141,1979 .

18. Donowitz, L.G., Marsik, F.J., Hogt, J.W. and Wenze I, R.P. Serratia marcescens bacteremia from contaminated pressure transducers. JAMA 242: $1949,1979$.

19. Garvey, G. Endovascular and prosthetic implant infections. In: M.H. Grieco, ed. Infections in the abnomal host. New York: Yorke Medical Books, 1980; 693.

20. Christensen, G.D., Simpson, W.A., Bisno, A.L. and Beachey, E.H. Adherence of slime-praducing strains of Staphylococous epidermidis to smooth surfaces. Infect. Immun. 37: 318,1982 . 
21. Sugarman, B. and Musher,D. Adherence of bacteria to suture materials. Proc.Exp.Biol.Med. 167: 156,1981.

22. Sugaman, B. In vitro adherence of bacteria to prosthetic vascular grafts. Infection 10: 9, 1982.

23. Kaplan, E.L., Castaneda, A.R., Ayoub, E.M. and Quie, P.G. Effects of cardiopulmonary bypass on the phagocytic and bactericidal capacities of polymorphonuclear leukocytes. Circulation 37 (supp. II): 158,1968.

24. Kusserow, B.K. and Larrow, R. Studies of leukocyte response to prolonged blood pumping - effects upon phagocytic capability and total white cel1 count. Trans.Amer. Soc.Artif. Intern.Organs, 14: 261,1968.

25. Kusserow, B., Larrow, R. and Nichols, J. Perfusion- and surfaceinduced injury in leukocytes. Fed.Proc.30: 1516,1971.

26. Silva, J.Jr., Hoeksema, H. and Fekety, F.R. Transient defects in phagocytic functions during cardiopulmonary bypass. U.Thorac. Cardiovasc. Surg. 67: 175,1973.

27. Subramanian, W., Lande, A.L., Gans, H., Lowman, J.T. and Li11ehei, C.W. Depression of host-defense mechanisn following extracorporeal circulation. Trans.Amer.Soc.Artif. Intern.Organs.15: 165,1969.

28. Northey, D., Adess, M.L., Hartsuck, J.M. and Rhoades, E.R. Microbial surveillance in a surgical intensive care unit. Surg.Gynecol. Obstet. 139: 321,1974 .

29. Levenson, S.M. and Laufman, H. Infection hazard of surgical intensive care: isolation procedures in the surgical intensive care unit. In: J.M.Kinney, H.H.Bendixen and S.R.Powers, eds. Manual of surgical intensive care. Philadelphia: W.B.Saunders Comp., 1977; 151.

30. Bernard, H.R. The control of infection. In: J.M. Kinney, H.H.Bendixen and S.R.Powers, eds. Manual of surgical intensive care. Philadelphia: W.B.Saunders Comp., 1977; 203. 
31. Goodman, J.S., Schaffner, W., Collins, H.A., Battersby, E.J. and Koenig, M.G. Infection after cardiovascular surgery. Clinical study including examination of antimicrobial prophylaxis. New. Engl.J.Med. 278: 117,1968 .

32. Conte, J.E. Ir., Cohen, S.N., Roe, B.B. and Elashoff, R.M. Antibiotic prophylaxis and cardiac surgery. A prospective double-blind comparison of single-dose versus multiple-dose regimens. Ann. Int. Med. $76,943,1972$.

33. Kini., P.M., Fernandez, M.D., Causay, R.S. and Lemole, G.M. Doubleblind comparison of cefazolin and cephalothin in open-heart surgery. J.Thorac. Cardiovasc.Surg. 76: 506,1978.

34. Cooper, D.K.C., Norton, R., Mobin, M.A., Cleland, W.P., Bentall, H.H. and Darre11, J.H. A comparison of two prophylactic antibiotic regimes for open-heart surgery. J.Cardiovasc. Surg. 21: 279,1980.

35. Lathrop, G.D., Brockett, R.M. and Blouse, L.E. Epidemiologic surveillance for Stophylooocous epidemitids infections, related to cardiopu1monary bypass. Zb1. Bakt. Hyg., I.Abt.Orig.A 241: 108,1978.

36. Mayer, K.H. and Schoenbaum, S.C. Evaluation and management of prosthetic valve endocarditis. Prog.Cardiovasc. Dis. 25: 43,1982.

37. Hughes, R.K. A method of improved anti-sepsis for open-heart surgery. Ann. Thorac.Surg. 2: $230,1966$.

38. Clark, R.E., Amos, W.C., Higgins, V., Benberg, K.F. and Weldon, C.S. Infection control in cardiac surgery. Surgery 79 : 89,1976.

39. Bredëe, J.J. Personal communication. 
CHAPTER VIII

SUMMARY 
Increasing attention has been given to the occurrence of infections following cardiac surgery (Chapter I). There are numerous risk factors for acquiring infections associated with the treatment of open-heart surgery patients. Postoperative infective endocarditis has been thoroughly studied, in contrast to extra-cardiac infections after open-heart surgery.

Survefllance has been advocated for the control of the incidence of hospital associated infections. The purpose of this study was to assess prospectively the efficacy of certain parts of an infection surveillance programme, as used during the first 18 months after commencing cardiac surgery in the Catharina Hospital at Eindhoven, The Netherlands.

In total 182 open-heart operations were performed in this period. Registration of postoperative infections was performed for 178 patients, as four patients died on the day of surgery. Infections were registered prospectively according to definitions described in Chapter II. In this chapter, the architectural design, the facilities of the department and the clinical procedures as applied before, during, and after open-heart operations are described in detail. In addition the incidences of infections are given. Postoperative infections occurred in $63(35 \%)$ patients of whom 11 had more than one infection. Early-onset bacterial endocarditis (BE) and septicaemia were each diagnosed in seven (3.9\%) patients. Lower respiratory tract infections occurred in $48(26,9 \%)$, bacteriuria in three $(1.7 \%)$, and wound infections in eight $(4.5 \%)$ patients.

Microorganisms causing postoperative infections can derive from numerous sources. The microbial flora of the patient present on admission to the department of cardiac surgery, can be such a source. Therefore preoperative microbiological culturing has been done in open-heart surgery patients, but its usefulness in pin-pointing the relation between the isolated microorganisms and those causing postoperative infections has not thoroughly been studied. In chapter III an attempt was made to find such a relation. The results showed that microorganisms present in the admission flora were involved in about one third of the postoperative infections. This suggests that most infections were due to microorganisms acquired during hospitalization. The majority of the septicaemia"s and BE's was caused by staphylococci, whereas lower respiratory tract and urinary tract infections were mainly caused by various Gram-negative species. From the infected wounds both staphylococci and Gram-negative microorganisms were isolated. Susceptibility testing of the isolates causing postoperative infections showed that about $70 \%$ of them were sensitive to cephalothin, the prophylactic antibiotic used. 
In addition, the results of culturing the tips of various indwelling devices after removal showed that the presence of microorganisms on these devices generally did not predict a subsequently occurring postoperative infection. Only cultures of the tip of the endotracheal tubes yielded similar microorganisms as those causing the lower respiratory tract infections in $69 \%$ of these infections.

The reliability of the sampling method for the detection of nasal and pharyngeal carriage of Stophylococous aupeus and the persistence of this carriage among patients and hospital personnel was investigated (Chapter IV). The accuracy of the swabbing technique was determined by sampling twice consecutively the nose and the throat of patients and hospital employees (initial examination). It was found that stoph.coureus was not present in the first sample from $8.3 \%$ of the patients harbouring this microorganism in their nose as revealed by the results of the second consecutive sample, and from $16.6 \%$ of the patients with stoph. cureus in the throat flora. Similar results after consecutive sampling were found among hospital employees. Re-sampling the nasal and pharyngeal mucosa of patients after two davs and of hospital employees after seven days (follow up examination) revealed that the presence of Stoph.oureus at these sites was rather transient, mainly due to a significant loss of this microorganism. This loss must be attributed to as yet unknown factors. Both the inaccuracy of the sampling method and the transiency of the presence of Stcph h.oux eus in the nose and throat f7ora of patients may explain why no relation was found between preoperative carriage of stcoph.caureus and the occurrence of postoperative infections due to this microorganism.

As part of the infection surveillance programme the contamination rate of the extra corporeal circuit was studied in Chapter V. Microorganisms were cultured from $31(25.6 \%)$ of the 121 samples from the priming solution before the extra corporeal circulation was initiated, and from six (5.0\%) out of 121 samples from the oxygenator blood at the end of the extra corporeal circulation. From the priming solution samples mainly Staphylococous epidermidis and Bacizuns species were cultured. From the oxygenator samples, Bacitlus species, Gram- positive and Gram-negative microorganisms as well as Aspergizzus species were isolated. No relation was found between the results of the bacteriological monitoring before and at the end of the extra corporeal circulation and the occurrence of postoperative bacteraemia, septicaemia and/or BE. Because an increased sampling frequency might enhance the number of positive samples the extra corporeal circuit. was 
studied in more detail in 45 operations. Although cumulation of the results of single and multiple sampling yielded 30 positive out of 45 examined extra corporeal circuits, again no relation could be demonstrated between the use of a contaminated circuit and the occurrence of postoperative bacteraemia, septicaemia and/or $B E$.

Although Stoph.epidermiais is generally considered to be a non-pathogenic microorganism, known as a frequent contaminant of blood cultures, it can cause serious postoperative infections especially after insertion of surgical prostheses. The diagnos is of a postoperative intravascular infection caused by stopk.epidermidis is based on its isolation from several blood cultures, to differentiate contaminated from valid positive blood cultures. In Chapter VI this problem was assessed by examining the results of concurrently taken paired blood samples from 273 patients after open-heart surgery. Seven (1.3\%) out of 537 paired samples contained Stoph.epidermidis in both cultures. Although the isolation of stoph.epidermidis from both blood cultures of a sample pair suggests a bacteraemia due to staph.epidermidis, statistical analysis showed that the seven paired blood samples could be explained to be positive for staph.epidermidis as a result of contamination. This was supported by the clinical course and by the results obtained from additional susceptibility testing and biotyping, which indicated non-identity of the isolated strains. 
CHAPTER IX

SAMENVATTING 
In de afgelopen decennia is in toenemende mate aandacht geschonken aan het probleem van het optreden wan infecties na hartchirurgie (hoofdstuk I). Patienten die een open-hartoperatie ondergaan zijn blootgesteld aan talrijke risicofactoren woor het krijgen van deze postoperatieve infecties. over postoperatieve endocarditis is veel meer geschreven dan over extracardiale infecties na open-hartchirurgie.

Infectiebewaking is een middel ter preventie van ziekenhuisinfecties. In dit proefschrift wordt een prospectief onderzoek beschreven naar enkele methoden ter bewaking van infecties. Deze methoden waren onderdeel van een infectiebewakingsprogramma toegepast tijdens de eerste 18 maanden na het beginnen van hartchirurgie in het Catharina Ziekenhuis te Eindhoven. In deze periode, van februari 1978 tot juni 1979, werden 182 open-hartoperaties verricht. Er werd een registratie gedaan van infecties die optraden na 178 van deze 182 open-hartoperaties, aangezien vier patienten stierven op de dag van de operatie. Deze registratie droeg een prospectief karakter en was gebaseerd op de in hoofdstuk II beschreven diagnostische criteria. In hoofdstuk II wordt tevens een voor deze studie relevante beschrijving gegeven van ruimtelijke en materiële voorzieningen van de cardio-chirurgische afdeling van het Catharina Ziekenhuis te Eindhoven, alsmede van de klinische procedures die onderdeel vornden wan de behandeling van de patient voor, tijdens en na een open-hartoperatie. Tenslotte worden in dit hoofdstuk de incidenties van infecties optredend na deze 178 open-hartoperaties weergegeven. Vijfenzestig (35\%) patienten makten een postoperatieve infectie door warvan 11 neer dan één infectie. Vroeg optredende (binnen 60 dagen) postoperatieve endocarditis en postoperatieve sepsis traden elk op bij zeven (3.9\%) patienten. Postoperatieve lage luchtweginfecties werden gezien biji $48(26.9 \%)$, bacteriurie bij drie (1.7\%) en postoperatieve wondinfecties bij acht $(4.5 \%)$ van de 178 patienten.

De microörganismen die postoperatieve infecties veroorzaken kunnen wit diverse bronnen afkomstig zijn. De microbiële flora wan de open-hartpatienten zelf, zoals aanwezig op de eerste dag van de opname, kan een dergelijk bron zijn. Daarom worden in sonmige cardio-chirurgische klinieken pre-operatief bacteriologische kweekuitstrijkjes genomen van diverse plaatsen van de huid en slijnvliezen van open-hartoperatiepatienten. Er is echter nooit een grondige studie verricht naar de warde van een dergelijk bacteriologisch onderzoek, met als doel het bestuderen van de relatie tussen de microörganismen die eenmalig pre-operatief van de patient gekweekt worden en de microöganismen die postoperatief infecties veroorzaken. In hoofdstuk 
III worden de resultaten wan een dergelijk onderzoek weergegeven. Deze toonden aan dat bij ongeveer ếnderde van de postoperatieve infecties een gelijksoortig microdrganisme geisoleerd werd als uit de pre-operatieve kweken van de patient. Dit suggereert dat het merendeel van de infecties veroorzatkt werd door microörganismen waamee de patient tijdens het verblijf in het ziekenhuis gekoloniseerd werd. Postoperatieve endocarditis en sepsis werden voor het grootste gedeelte veroorzaakt door staphylococcen terwijl bij lage luchtweg- en urineweginfecties vooral Gram negatieve microörganismen werden geisoleerd. Wondinfecties werden zowel door Gram negatieve als Gram positieve microörganismen veroorzaakt. In zeventig procent van de infecties waren de micrö̈rganismen gevoelig voor thet als profylactisch antibioticum toegediende cephalotine, zoals bleek uit de resistentiebepaling van de isolaten. In dit hoofdstuk werd aan de hand van de resultaten van de kweken van de tip van de bij de patient verwijderde intravasculaire lijnen, wonddrains en urinecatheters aangetoond dat de aanwezigheid van microörganismen op de tip wan deze lijnen en drains een postoperatieve infectie veroorzakt door dezelfde microörganismen, over het algemeen niet kon voorspellen. Alleen biji $69 \%$ wan de patienten met een lage luchtweginfectie werd een gelijksoortig microörganisme gekweekt van de tip van de endotracheale tube.

De betrouwbaarheid van de uitstrijkmethode ter opsporing van neus- en keeldragers van staphyzococous aureus onder patienten en ziekenhwispersoneel en de continuiteit van dit dragerschap in de tijd was doel van onderzoek in hoofdstuk IV. De nauwkeurigheid van de witstrijktechniek werd onderzocht door mïdel van twee direct na elkaar uitgevoerde kweekuitstrijken uit de neus en kee] van patienten en ziekenhuispersoneel (eerste onderzoek). Van de patienten zou $8.3 \%$ niet als staph.oureus neusdragers en $16.6 \%$ niet als stoph.coureus keeldragers herkend zijn als slechts éenmal uitgestreken was. Tweemal uitstrijken van de neus en keel van het ziekenhuispersoneel leverde gelijkwaardige percentages op. De continuiteit van het staph. aureus neus-en kee 1dragerschap werd anderzocht door de keel- en neusflora opnieuw te onderzoeken (tweede onderzoek) met behulp van ëen uitstrijkje op de tweede dag na het eerste onderzoek bij de patienten en op de zevende dag bij het ziekenhuispersoneel. De aanwezigheid van staph. carreus in de neus- en keelfiora bleek uit dit tweede onderzoek in beide graepen niet constant, woornamelijk als gevolg van het verdwijnen van dit microörganisme uit de neus - en keelflora. Wij konden dit verlies niet verklaren. De beperking van de uitstrijktechniek en de in tijd variabele aanwezigheid van Stoph. axreus in de neus-en keelflora van patienten zouden een verklaring kunnen zijn voor het door 
ons niet kunnen vaststellen van de relatie tussen het preoperatief dragerschap van Staph. oureus bij patienten en het optreden van postoperatieve infecties door dit microorganisme. Deze relatie werd door anderen wel aangetoond.

Een ander onderdeel van het infectiebewakingsprogramma, het bacteriologisch bewaken van het extracorporele circuit voor en tijdens de extracorporele circulatie, is onderwerp van de studie beschreven in hoofdstuk $\checkmark$. Voor het begin en tegen het einde van de extracorporele circulatie werd een kweekmonster afgenomen uit de inhoud van het circuit. Uit 31 (25.6\%) van de 121 kweekmonsters van de vloeistof warmee het circuit voor de extracorporele circulatie werd gevuld, werden microörganismen gekweekt. Zes $(5.0 \%)$ van de 121 kweekmonsters van het bloed van de oxygenator, afgenomen op het einde van de extracorporele circulatie, waren positief. Uit de circuitvloeistof voor aanvang van extracorporele circulatie werden vooral staphyzococous epidemidis en Bacilzus gekweekt, terwijl uit de oxygenatomonsters Bacizzus, AspergizZas, Gram positieve en Gram negatieve microörganismen werden geisoleerd. Er werd geen verband gevonden tussen de resultaten van het bacteriologisch onderzoek van de inhoud van het extracorporele circuit voor begin en einde van de extracorporele circulatie en het optreden van postoperatieve bacteriaemie, sepsis en/of endocarditis. Het onderzoek naar de warde van het bacteriologisch bewaken van het extracorporele circuit werd uitgebreid tijdens 45 operaties, veronderstellend dat een groter aantal kweekmonsters een toename van het aantal positieve monsters zou laten zien. Hoewel onder deze 45 operaties, waarbij frequenter bloedkweken werden afgenomen, 30 gecontamineerde circulits werden gevonden, werd wederom geen relatie vastgesteld met het optreden van post-operatieve bacteriaemie, sepsis en/of endocarditis na deze 45 operaties.

Staph.eptademidta wordt over het algeneen beschouwd als een niet pathogeen microönganisme. Het wordt regelmatig als contaminant uit bloedkweken geisoleerd. Staph.epidemidia kan echter postoperatieve infecties veroorzaken vooral na implantatie van een chirurgische prothese. Voor de diagnostiek van postoperatieve intravasculaire infecties veroorzakt door staph. epidemidis is het belangrijk een onderscheid te maken tussen een staph.eptatemidis positieve bloedkweek ten gevolge van contaminatie dan wel ten gevolge van bacteriaenie. Dit kan door middel van herhaaldelijk isoleren van dit microörganisme uit een serie bloedkweken. In hoofdstuk VI worden de resultaten besproken van 537 paarsgewijze afgenomen bloedkweken afkomstig van 273 patienten na open-hartchirurgie. Beide bloedkweken van zeven (1.3\%) gepaarde 
monsters bevatten staph.epidemidis. Hoewel de isolatie van stoph.eptameridu wit beide kweekmonsters van paarsgewijs afgenomen bloedkweken suggestief is voor een bacteriamie door Staph.epidermidis, kon de isolatie van staph. epidemiazs uit deze zeven gepaarde bloedkweken op statistische gronden verklaard worden door contaminatie. Deze bevinding werd ondersteund door het: postoperatieve klinisch beloop bij deze patienten en door aanwullend onderzoek van het resistentiepatroon en het biotype van deze stammen, die de ongelijkheid van deze isolaten aantoonden. 


\section{Dankbetuiging}

Het materiaal voor het onderzoek beschreven in dit proefschrift werd verzameld in het Catharina Ziekenhuis te Eindhoven.

Velen hebben op êến of andere wijze hun bijdrage geleverd aan de verwezenlijking van dit proefschrift. Het lijkt haast ondoenlijk een ieder hiervoor persoonlijk te vermelden, gezien het grote aantal betrokkenen. Allen die, in welke mate dan ook, ergens op de lange weg naar de voltooing hum medewerking hebben verleend, dank ik oprecht voor hun inzet.

Enkele personen wil ik apart vermelden, in chronalogische volgorde van betrokkenheid, in de hoop dat mijn erkentelijkheid jegens hen die onbesproken blijven hierdoor njet in kracht inboet.

Dr.J.Bredée en drs.Y.Mashour, cardiochirurgen van het Catharine Ziekenhuis te Eindhoven, en Dr. M. Haverkorn, Hoofd van het Laboratorium voor Medische Microbiologie te Eindhoven, hebben mijn belangstelling gewekt voor het probleem en de noodzaak doen inzien van infectiebewaking in open-hartchirurgie. Mijn eerste activiteiten op het terrein van het wetenschappelijk onderzoek in het algemeen en met betrekking tot dit onderwerp in het bijzonder vonden plaats door hun stimulans en enthousiasme. Administratief en moreel waren vooral Mw. D. Weenink maar ook de andere dames van het secretariaat cardiochirurgie hierin een grote steun.

De medewerkers van de afdeling extra corporele circulatie, de verpleegkundigen van de operatiekamer, van de intensive care, en van de afdeling 7 West, alsmede de collegae intensivisten, de medewerkers van het $k l$ inischchemisch laboratorium, van de röntgenafdeling en van de afdeling fysiotherapie van het Catharina Ziekenhuis te Eindhoven hebben hun medewerking verleend aan het verzamelen wan gegevens, waarvoor mi.jn dank.

Mw. Willekens, bibliothecaresse van het Catharina Ziekenhuis heeft mij op deskundige wijze bijgestaan in het verzamelen van de literatuur.

De directie van het Catharine Ziekenhuis heeft van meet af aan steun verleend aan het onderzoek, waarvoor ik haar zeer erkentelijk ben.

Het omvangrijk bacteriologisch onderzoek werd verricht op het Laboratorium voor Medische Microbiologie te Eindhoven (Hoofd:

Dr.M.Haverkorn) en op het Laboratorium van de Capaciteitsgroep Medische Micrabiologie van de Rijksuniversiteit Limburg (Hoofd: Prof.Dr.C.van Boven). De enthousiaste medewerking van onder andere Mw.H. de Wilde, de Heer A.Dorst, Dr. M. Hawerkorn, respectieve1ijk Dr. E.Stobberingh en Prof.Dr. C. van Boven heeft mij enorm gestimuleerd. 
Toen het onderzoek promovabele vomen begon aan te nemen hebben Prof.Dr.J.Homan van der Heide en drs. J.Dankert zich bereid verklaard mij verder te begeleiden op de weg nar voltooing varn het proefschrift, mespectievelijk als promotor en co-promotor. In een later stadium heeft Prof.Dr. C. van Boven de gelegenheid geboden de promotie in Mastricht te laten plaatswinden en heeft hij ais promotor zijn enthousiaste begeleiding gegeven.

Bij de verwerking wan de gegevens onderwond $7 k$ alle steun en deskundige medewerking wan Dr. Ir. N. Linssen (Technische Hogeschool Eindhoven), Ir.L. van der Stee en Dr. Ir.H. Journêe (Afdeling Neurochirurgie, Academisch Ziekenhuis Groningen), en dra. A.Staal.

Mw.D. Weenink, Mw.M. Wiersma, Mw.G.Bathoorn en Mw.B.Hittenberger dank ik hartelijk voor het vele en goede typewerk.

Prof.Dr.D.Klein, Prof.Dr.H.STuiter, Dr.J.Bredëe, drs.Y.Mashour, Mw. H. Mashour, drs.P. Hendel, drs. A. Buchthal en drs.S. Terpstra dank ik voor hun kritische opmerkingen over inhoud en taal, en de Heer D. Buiter en Mevr. N. Putman voor de grafische verzorging van het proefschrift.

Mijn promotores, Prof.Dr.J. Homan van der Heide en Prof.Dr.C.van Boven, en bovenal mijn co-promotor drs.J. Dankert dank ik zeer voor thum enome toewijding en inzet die, nadat de basis van het werk in Eindhoven dankziji de medewerking van Dr.M. Haverkorm, Dr.J.Bredêe en drs. Y. Mashour was gelegd, de totstandkoming van dit proefschrift mede hebben doen verwezenlijken.

Prof.Or.G.Kootstra, Prof.Dr.G.Flendrig en Dr.M.Haverkorn ben ik zeer erkentelijk voor hun bereidheid als referent te willen hebben optreden en als zodanig hun kritisch en wardevol commentaar op het manuscript gegeven te hebben.

Zonder de jarenlange actieve en passieve steun van mijn dierbare vrouw was dit proefschrift nooit tot stand gekomen.

Tenslotte betuig ik mijn dank aan de Nederlandse Hartstichting die de publicatie van dit proefschrift financieel heeft ondersteund. 


\section{CURRICULUM VITAE}

The author of this thesis was born in Ansterdam on the 17th of August. 1949. He attended the European School of Brussels, where in Jume 1967 he obtained his European Baccalaureat. In November 1974 he graduated from the Medical Faculty of the University of Utrecht. The following year he fulfilled a supplementary medical training in order to work at a missionary hospital in Uganda as a general physician where he worked from 1975 to 1977. After his return to The Netherlands he was a junior resident in the department of cardiac surgery of the Catharina Hospital at Eindhoven. During this time he became interested in surveillance of infections in open-heart surgery. The fruit of this interest is this thesis. In January 1980 he started training generall surgery at the same hospital (Head of the Department: Dr. J.G.Prins). This enabled him to continue his training in meurosurgery which he started in July 1981 at the Neurosurgical Department of the University Hospital of Groningen (Head: Prof. Dr. J.W.F.Beks). 